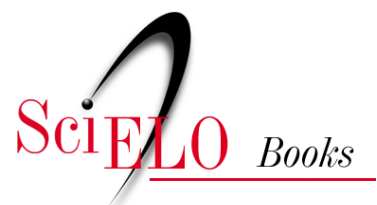

\title{
Educação infantil
}

discurso, legislação e práticas institucionais

Lucimary Bernabé Pedrosa de Andrade

ANDRADE, LBP. Educação infantil: discurso, legislação e práticas institucionais [online]. São Paulo: Editora UNESP; São Paulo: Cultura Acadêmica, 2010. 193 p. ISBN 978-85-7983-085-3. Available from SciELO Books <http://books.scielo.org>.

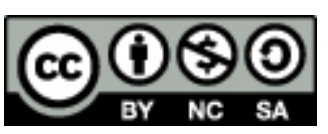

All the contents of this work, except where otherwise noted, is licensed under a Creative Commons Attribution-Non Commercial-ShareAlike 3.0 Unported.

Todo o conteúdo deste trabalho, exceto quando houver ressalva, é publicado sob a licença Creative Commons Atribuição Uso Não Comercial - Partilha nos Mesmos Termos 3.0 Não adaptada.

Todo el contenido de esta obra, excepto donde se indique lo contrario, está bajo licencia de la licencia Creative Commons Reconocimento-NoComercial-CompartirIgual 3.0 Unported. 


\section{EDUCAÇÃO INFANTIL}


Conselho Editorial Acadêmico

Responsável pela publicação desta obra

Prof. Dr. Pe. Mário José Filho (Coordenador)

Profa. Dra. Cirlene Ap. Hilário da Silva Oliveira (Vice-coordenadora)

Profa. Dra. Helen Barbosa Raiz Engler

Prof. Dr. José Walter Canôas 


\section{LUCIMARY BERNABÉ PEDROSA DE ANDRADE}

\section{EDUCAÇÃO INFANTIL Discurso, legislaçÃo E PRÁTICAS INSTITUCIONAIS}


(C) 2010 Editora UNESP

\section{Cultura Acadêmica}

Praça da Sé, 108

01001-900 - São Paulo - SP

Tel.: (0xx1 1) 3242-7171

Fax: (0xx 1 1) 3242-7172

www.editoraunesp.com.br

feu@editora.unesp.br

CIP- Brasil. Catalogação na fonte

Sindicato Nacional dos Editores de Livros, RJ

A565e

Andrade, Lucimary Bernabé Pedrosa de

Educação infantil : discurso, legislação e práticas institucionais /

Lucimary Bernabé Pedrosa de Andrade. - São Paulo : Cultura

Acadêmica, 2010.

194p. : il.

Inclui bibliografia

ISBN 978-85-7983-085-3

1. Educação de crianças. 2. Crianças - Formação. 3. Direito das crianças. 4. Crianças - Política governamental - Brasil.

5. Representações sociais. I. Título.

10-6448.

CDD: 372.21

CDU: 372.3

Este livro é publicado pelo Programa de Publicações Digitais da Pró-Reitoria de Pós-Graduação da Universidade Estadual Paulista "Júlio de Mesquita Filho" (UNESP)

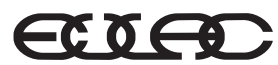

Asociación de Editoriales Universitarias de América Latina y el Caribe

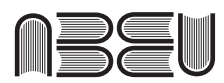

Associação Brasileira de Editoras Universitárias 
Às minhas queridas filhas

Natália e Maria Flávia, por partilharem dos meus sonhos, das minhas lutas, e por renovarem, a cada dia, minhas forças para a caminhada. 



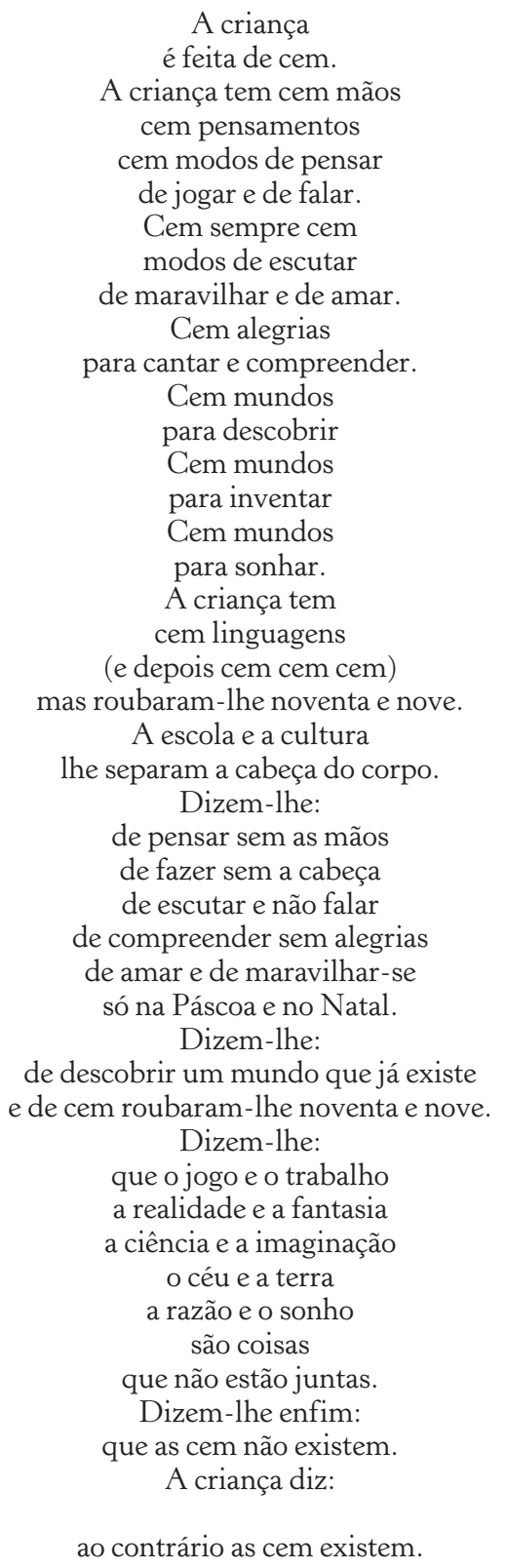





\section{SUMÁRIO}

Lista de siglas 11

Lista de tabelas 13

Lista de quadros 15

Introdução 17

Percurso metodológico 29

Tecendo os fios da infância 47

Direitos da infância: da tutela e proteção à cidadania e educação 79

A educação infantil: na trilha do direito 127

Considerações finais 169

Referências bibliográficas 179 



\section{LISTA DE SIGLAS}

CCI Centro de Convivência Infantil

CLT Consolidação das Leis do Trabalho

Coedi Coordenadoria de Educação Infantil

DPE Departamento de Políticas de Educação Infantil

ECA Estatuto da Criança e do Adolescente

Febem Fundação Estadual do Bem-Estar do Menor

Funabem Fundação Nacional do Bem-Estar do Menor

Fundeb Fundo de Manutenção e Desenvolvimento da

Educação Básica e Valorização dos Profissionais

da Educação

IBGE Instituto Brasileiro de Geografia e Estatística

LBA Legião Brasileira de Assistência

LDB Lei de Diretrizes e Bases da Educação Nacional

Loas Lei Orgânica de Assistência Social

MEC Ministério da Educação e Cultura

OIT Organização Internacional do Trabalho

ONU Organização das Nações Unidas

PNE Plano Nacional de Educação

Unesco Organização das Nações Unidas para Ciência, Educação e Cultura

Unicef Fundo das Nações Unidas para Infância 



\section{LISTA DE TABELAS}

Tabela 1 Escolaridade das educadoras $\quad 45$

Tabela 2 Tempo de exercício profissional 46

Tabela 3 Experiência profissional 46

Tabela 4 Funções da educação infantil 120

Tabela 5 Organização das práticas pedagógicas 163 



\section{LISTA DE QUADROS}

Quadro 1 Universo da pesquisa 37

Quadro 2 Número de crianças atendidas nas creches conveniadas e municipais de 2004 a $2008 \quad 40$ 



\section{INTRODUÇÃO}

Não tenho medo de que meu tema possa, em exame mais detalhado, parecer trivial. Receio apenas que eu possa parecer presunçoso por ter

levantado uma questão tão vasta e tão importante.

Carr, 1996

A proximidade com o objeto de estudo desta pesquisa, ou seja, a criança, seus direitos e sua educação, iniciou-se aos meus dezessete anos de idade, quando comecei minha trajetória profissional como professora de educação infantil em uma escola maternal particular.

Após conclusão do curso de Magistério, ingressei no curso de graduação em Serviço Social da Faculdade de História e Serviço Social da UNESP de Franca.

As frequentes indagações a respeito do papel social da educação, fomentadas pela experiência profissional em educação infantil, levaram-me a desenvolver minha monografia de conclusão do curso de Serviço Social sobre o atendimento das creches de Franca. Assustava-me a diferente realidade educacional vivenciada pelas crianças com as quais trabalhava na escola maternal par- 
ticular e as crianças das creches pesquisadas. Enquanto meus alunos, todos de classe social abastada, tinham acesso a educação de qualidade, a brinquedos e materiais pedagógicos diferenciados, a professores qualificados e espaços favoráveis para o seu desenvolvimento, as crianças que frequentavam as creches pesquisadas eram privadas de um atendimento que lhes propiciasse um desenvolvimento adequado. Esse contexto, não muito diferente do atual, nos permite inferir que o nosso sistema educacional excludente não assola apenas os níveis fundamental, médio ou superior de ensino.

Lembro que, ao chegar a uma das creches pesquisadas, a coordenadora, cheia de orgulho, solicitou que as crianças cantassem a "musiquinha para a visita", canção cuja letra ainda lembro bem: "Criança bonita, bem-educada, em casa ou na rua sempre delicada. Faz sua tarefa não fica à toa. Criança bonita é criança boa. Bate o sininho a fila formou, sempre caladinho tomar leitinho eu vou". Podemos perceber que o silêncio, a obediência, a fila e os ensinamentos morais eram ressaltados na educação das crianças, caracterizando o que Kuhlmann Júnior (2001, p.182) designa como pedagogia da submissão.

Experiências assim me fizeram fortalecer a ideia de que todas as crianças devem ter o direito a uma educação infantil de qualidade, pautada em um projeto educativo emancipatório, que promova o desenvolvimento de suas potencialidades e contribua para uma participação ativa e efetiva na sociedade.

Concluído o curso de Serviço Social, em dezembro de 1989, comecei a trabalhar, no mesmo ano, como assistente social em uma creche comunitária filantrópica mantida pela maçonaria, em um bairro da periferia da cidade. Os receios e anseios com a primeira experiência profissional como assistente social puderam ser amenizados com a experiência na educação infantil.

A identificação com o trabalho profissional na área de educação contribuiu para que, em 1992, fosse admitida no concurso público para a função de coordenadora do Centro de Convivência Infantil "Pintando o Sete", da UNESP de Franca (CCI), função que desempenho até os dias atuais. No CCI, pude ampliar os estudos sobre a 
infância e a educação infantil e fortalecer meus ideais sobre os direitos das crianças a um atendimento de qualidade, que respeite suas particularidades de sujeitos em desenvolvimento.

Buscando o aprimoramento profissional e a continuação dos estudos na área de educação infantil, ingressei, em 1999, no curso de Pedagogia da Universidade de Franca. O retorno à universidade despertou-me o desejo de continuar os estudos acadêmicos, o que me fez optar pelo curso de Pós-Graduação em Serviço Social, após a conclusão do curso de Pedagogia.

Em 2001, ingressei como aluna regular do curso de mestrado em Serviço Social, concluindo-o em 2003, quando defendi a dissertação: Os Centros de Convivência Infantil da UNESP: contexto e desafios, desenvolvida sob a orientação da profa. Maria Ângela Rodrigues Alves de Andrade. A pesquisa permitiu o aprofundamento teórico do estudo das políticas públicas para a infância no Brasil, e teve como objeto de investigação a creche no local de trabalho, em nosso caso, a Universidade Estadual Paulista.

Novas inquietações e indagações acerca desse campo de estudo foram surgindo e, em 2006, ingressei no curso de doutorado com o propósito de estudar a educação infantil enquanto um dos direitos da criança na contemporaneidade. A discussão em torno dos direitos das crianças tem sido apresentada por muitos estudos e pesquisas, os quais têm enfatizado a relevância das ações dos profissionais que atuam com a infância para que esses direitos sejam efetivados de fato.

Por acreditar na importância de aprofundar o estudo sobre essa problemática é que procuraremos compreender como as profissionais que atuam diretamente com as crianças nas creches, ou seja, as educadoras, compreendem a criança, seus direitos e sua educação e de que forma suas ações favorecem, ou não, que as crianças sejam sujeitos de direitos nesses espaços institucionais.

Segundo Dahlberg, Moss \& Pence (2003, p.63), os entendimentos que temos do que seja a infância e a criança perpassa as nossas vivências, os nossos conhecimentos científicos e as nossas escolhas. 
Para isto, torna-se importante um olhar mais atento ao entendimento das representações das categorias que moldam as ações cotidianas dos profissionais das creches, pois em diferentes períodos históricos foram construídas diferentes representações e significações dessas categorias.

Conforme as contribuições da Sociologia da Infância, é importante que façamos a análise crítica das representações sobre a categoria infância, considerando que estas se modificam conforme cada contexto histórico. A Sociologia da Infância, ao constituir a infância como objeto sociológico, afirma a condição da criança como sujeito social cujo desenvolvimento está articulado às suas condições sociais de existência e às representações e imagens historicamente construídas.

Conforme Sarmento (2005, p.363):

A sociologia da infância propõe-se a constituir a infância como objecto sociológico, resgatando-a das perspectivas biologistas, que a reduzem a um estado intermédio de maturação e desenvolvimento humano, e psicologizantes, que tendem a interpretar as crianças como indivíduos que se desenvolvem independentemente da construção social das suas condições de existência e das representações e imagens historicamente construídas sobre e para eles. Porém, mais do que isso, a sociologia da infância propõe-se a interrogar a sociedade a partir de um ponto de vista que toma as crianças como objecto de investigação sociológica por direito próprio, fazendo acrescer o conhecimento, não apenas sobre infância, mas sobre o conjunto da sociedade globalmente considerada.

Os estudos científicos propagados a partir do século XX, em especial da Psicologia, Antropologia, Sociologia e História, apresentam uma visão de infância como categoria social e historicamente construída, determinando um conjunto de teorias e práticas a serem desenvolvidas com as crianças, tanto nas famílias como nas instituições de educação infantil, e, ainda, influenciam as re- 
presentações sociais sobre as crianças incorporadas ao imaginário coletivo.

Atualmente, as crianças recebem o estatuto de sujeitos plenos de direitos, ganhando a infância uma visibilidade internacional.

A visibilidade contemporânea da infância é revelada por dispositivos legais de âmbito internacional que, apesar de apresentarem um discurso social e político sobre a infância de direitos, revelam o caráter paradoxal dessa visibilidade:

[...] ao falar-se (e ao estudar-se) as crianças, produzem-se, na ordem do discurso e na ordem das políticas sociais, efeitos contraditórios, que resultam da extrema complexidade social da infância e da heterogeneidade das condições de vida. (Pinto \& Sarmento, 1997, p.14)

Segundo Pinto e Sarmento, um dos maiores paradoxos consiste nas inconsistências da agenda política da infância, pois no momento em que há um discurso oficial e legal afirmando serem elas o futuro da sociedade, temos um quadro de opressão a que é submetida grande parte da população infantil do mundo. Qvortup assim esclarece esse caráter paradoxal:

[...] no facto de os adultos desejarem e gostarem das crianças, apesar de "produzirem" cada vez menos crianças e cada vez disporem de menos tempo e espaços para elas; no facto de os adultos acreditarem que é bom para as crianças e os pais estarem juntos, mas cada vez mais vivem o seu cotidiano separados uns dos outros; no facto de os adultos valorizarem a espontaneidade das crianças, mas a vida das crianças ser submetida às regras das instituições; no facto de os adultos postularem que deve ser dada prioridade às crianças, mas cada vez mais as decisões políticas e econômicas com efeito na vida das crianças serem tomadas sem as ter em conta. (Qvortup, 1995, p.9 apud Pinto \& Sarmento, 1997, p.12-3) 
Esse paradoxo assola sobremaneira a realidade brasileira, marcada por um quadro de miséria, abandono, exploração e violação dos direitos de grande parte da população infantil proclamados com a Constituição Federal (1988) e com o Estatuto da Criança e do Adolescente - ECA (1990).

Segundo dados do Unicef, 2008, o Brasil possui a maior população infantil de até seis anos das Américas, representando 11\% de toda a população brasileira. Conforme os dados socioeconômicos, a grande maioria das crianças na primeira infância se encontra em situação de pobreza. Aproximadamente 11,5 milhões de crianças, ou $56 \%$ das crianças brasileiras de até seis anos de idade, vivem em famílias cuja renda mensal está abaixo de $1 / 2$ salário mínimo per capita por mês. Os dados estatísticos revelam, ainda, que as crianças são especialmente vulneráveis às violações de direitos, à pobreza e à iniquidade, e as crianças negras apresentam quase $70 \%$ mais de chance de viver na pobreza do que as brancas.

Ao percorrermos a trajetória da infância constatamos que o caráter paradoxal é uma constante histórica, visto que a criança e seus direitos sempre foram discutidos em situações contraditórias.

A compreensão desse caráter paradoxal é de fundamental importância para pensarmos no trabalho a ser realizado nas instituições de educação infantil, no ensejo de que esses espaços possam ser espaços de concretude da cidadania da infância, pois, apesar do vasto campo de conhecimentos produzidos sobre a infância, encontramos muitas dificuldades no trabalho com as crianças e na efetivação de seus direitos sociais.

Segundo Sarmento (2007, p.26), a presença de sucessivas representações das imagens sociais da infância ao longo da história produziu um efeito de invisibilidade da infância na sociedade.

Historicamente, as concepções de infância, direitos das crianças e educação infantil foram modificando-se em decorrência das transformações econômicas, políticas, sociais e culturais ocorridas na sociedade, ocasionando a implantação de determinadas políticas públicas para a infância vinculadas às diferentes esferas de atuação governamental, como a assistência social, a saúde e a educação. 
Torna-se importante, ainda, pontuar que a história do atendimento relacionado à educação infantil no Brasil corresponde a múltiplas determinações da reprodução da vida social, visto que as instituições de educação da criança pequena estão em estreita relação com as questões que dizem respeito à história da infância, da família, da população, da urbanização, do trabalho e das relações de produção.

Atualmente, o reconhecimento da criança enquanto sujeito social e histórico, detentora de direitos sociais, faz da educação infantil uma exigência social, ocupando no cenário da educação brasileira um espaço significativo e relevante. Paralelamente ao quadro de transformações societárias aliadas aos movimentos sociais e estudos acerca da infância, tem sido intensificado o reconhecimento da importância da educação das crianças para o pleno desenvolvimento das potencialidades do ser humano.

Dentre os fatores que contribuíram para o aumento da demanda do atendimento da educação infantil no país, podem-se citar o avanço científico sobre o desenvolvimento infantil, a crescente inserção da mulher no mercado de trabalho e o reconhecimento da criança como sujeito de direitos, especialmente em seus primeiros anos de vida.

A Constituição Federal de 1988, em relação às políticas de atenção à infância, inaugurou um novo momento na história da legislação infantil ao reconhecer a criança como cidadã. Ao contemplar o direito das crianças pequenas à educação estabeleceu, como dever do Estado, a garantia do atendimento em creches e pré-escolas às crianças de 0 a 6 anos. Dessa forma, as creches começaram a fazer parte das políticas públicas enquanto instituições educativas.

O Estatuto da Criança e do Adolescente (ECA), Lei n. $8.069 / 1990$, ordenamento legal que reitera a criança como sujeito de direitos, no artigo 53 referencia a contribuição da educação no desenvolvimento pleno da pessoa, na conquista da cidadania e na qualificação para o trabalho, destacando, ainda, aspectos fundamentais da educação, como política pública, quanto 
à necessidade de igualdade de condições para o acesso à escola pública.

A nova Lei de Diretrizes e Bases da Educação Nacional (LDB), Lei n. 9.394/1996, no artigo 29, defende a educação infantil como primeira etapa da educação básica, tendo como objetivo "o desenvolvimento integral da criança até seis anos de idade, em seus aspectos físicos, psicológicos, intelectual e social, complementando a ação da família e da comunidade". De acordo com a referida lei, as instituições que atendem as crianças de 0 a 6 anos são denominadas de creches e pré-escolas e diferenciadas exclusivamente pelo critério etário, ou seja, creche para o atendimento às crianças de $0 \mathrm{a}$ 3 anos de idade e pré-escola às crianças de 4 a 6 anos.

Embora tenhamos um quadro legal em defesa dos direitos da infância, grande parte dos mesmos não foi efetivada, o que requer a intensificação das lutas pelos direitos das crianças em nossa sociedade.

A história dos dispositivos legais acerca da infância, seus direitos e sua educação retrata um percurso histórico marcado por programas fragmentados e relações antagônicas entre a assistência e a educação.

Dessa forma, podemos observar no cenário da educação infantil a presença de políticas públicas focalizadas, seletivas e compensatórias, expressas pelo número reduzido de creches mantidas pelo poder público, pela predominância de critérios socioeconômicos e exigência do trabalho materno no preenchimento de vagas nas instituições, pela indefinição orçamentária, pelos embates nos objetivos pedagógicos propostos, etc.

Diante dessas argumentações é que consideramos importante discutir como os direitos das crianças estão sendo efetivados no cotidiano das creches, e qual a contribuição dos profissionais que atuam no âmbito dessas instituições para a legitimidade da cidadania da infância.

Acreditamos que a ruptura com as práticas assistencialistas somente poderá efetivar-se com uma política institucional comprometida com a infância, com base na consolidação de novas 
relações sociais entre os sujeitos envolvidos: crianças, famílias e profissionais. É importante, ainda, destacarmos a necessidade do rompimento de práticas profissionais rotineiras, burocráticas e individuais, considerando que a interdisciplinaridade com outras áreas do saber na creche será imprescindível ao projeto educativo.

Levando em conta as mudanças teóricas e legais no campo da educação infantil nas últimas décadas, será que realmente podemos afirmar que as crianças são sujeitos de direitos nos espaços das instituições de educação infantil? Será que os profissionais dessas instituições superaram a visão adultocêntrica no atendimento às crianças? As crianças estão sendo respeitadas em seus direitos sociais e fundamentais exercendo o papel de protagonistas no contexto institucional?

Temos como propósito, através da realização desta pesquisa, a construção de conhecimentos que favoreçam o debate da creche como instituição educativa e espaço de exercício da cidadania da infância.

A legitimidade educacional das creches implica a transformação de suas práticas institucionais e das concepções sobre sua função social, tanto por parte dos usuários de seus serviços como dos profissionais que nelas trabalham.

Consideramos relevante a elaboração de práticas pedagógicas que, articulando cuidados e educação, reconheçam as crianças como não meros depositários de conteúdos, porém protagonistas desses espaços institucionais, sujeitos ativos e produtores de cultura.

O trabalho dos profissionais que atuam nas creches deverá romper com os traços assistencialistas, comprometendo-se na construção de práticas emancipatórias destinadas à formação de cidadãos. Observamos, ainda, a necessidade de superação da distância existente entre os discursos legal e pedagógico propagados a partir das últimas décadas e as práticas institucionais desenvolvidas com as crianças.

A presente pesquisa tem como objetivo analisar as concepções dos conceitos de criança, direitos da infância e educação infantil apresentadas pelas educadoras das creches e de que forma elas 
manifestam essas categorias, no discurso e na organização das práticas institucionais.

Outros objetivos também permeiam a investigação, tais como: compreender e analisar como a educação infantil, enquanto política pública, tem sido efetivada nas políticas de atendimento das creches de Franca, conhecer os avanços e os limites da atuação dos profissionais das creches, contribuir para o desenvolvimento de uma política de atendimento nas creches capaz de favorecer o desenvolvimento pleno das crianças e a construção de um projeto político-pedagógico pautado nos direitos da infância.

A pesquisa bibliográfica foi realizada paralelamente à pesquisa de campo, e, assim, optamos por uma construção textual que permitisse o diálogo e as reflexões entre as discussões teóricas e as representações dos sujeitos da pesquisa.

Dessa forma, apresentaremos a discussão das concepções de alguns autores acerca da temática estudada e em seguida faremos a discussão dos dados da pesquisa, a partir das seguintes categorias de análise: representações da infância: entre a natureza e a cultura; representações sobre os direitos da infância: a educação e o brincar; e representações sobre a educação infantil: discursos e práticas.

No primeiro capítulo descreveremos o percurso metodológico da pesquisa e abordaremos o aporte teórico-metodológico das representações sociais.

No segundo capítulo apresentaremos a construção histórica da infância e as representações dessa categoria no âmbito teórico e na prática dos profissionais das creches. Discutir a categoria infância não é tarefa fácil em face da complexidade de questões que a perpassam. No diálogo com alguns autores, dentre eles, Pinto \& Sarmento (1997), Sarmento (1997, 2001, 2004, 2007), Kuhlmann Júnior (2001), Kramer (2003a), Moss (2002) e Dahlberg, Moss \& Pence (2003), discutiremos a concepção de infância enquanto categoria historicamente construída e buscaremos refletir sobre as representações de infância que subsidiam a prática dos profissionais da educação infantil na cidade de Franca. Considerando a 
perspectiva histórica e sociológica que permeará o referido capítulo, faremos a discussão da infância nas encruzilhadas da modernidade e pós-modernidade.

No terceiro capítulo discutiremos os direitos da infância, ressaltando aspectos históricos e a constituição do quadro legal que rege a infância no âmbito internacional e nacional. Destaque será dado ao quadro normativo que rege a educação infantil no Brasil, por ser considerado, dentre os direitos da infância, o objeto de estudo da presente pesquisa. Juntamente com a discussão teórica, apresentaremos as representações dos sujeitos da pesquisa sobre a educação infantil como um dos direitos do quadro normativo da infância brasileira.

A educação infantil, enquanto política pública e direito da infância, será analisada no quarto capítulo. Para discussão dessa categoria buscaremos na história do atendimento à infância, no Brasil, os fundamentos necessários para a sua compreensão, pois, como afirma Angotti (2006, p.17),

Elementos da história do atendimento à infância precisam e merecem ser conhecidos, entendidos e analisados para que se possam elaborar e manter a luta pelas condições educacionais que favorecem a inserção da criança na sociedade à qual pertence sua condição de direito em ser pessoa, em ser e viver as perspectivas sociopolíticas histórico e cultural que sustentem as bases do sujeito, protagonistas da história de seu próprio desenvolvimento, interlocutora de diálogo aberto com e em um mundo em permanente e absoluta dinamicidade.

Nesse capítulo serão apresentadas as representações sobre a educação infantil por meio da análise da organização das práticas pedagógicas nas instituições de educação infantil, permitindo o diálogo entre os discursos e as práticas profissionais.

Nas Considerações Finais, destacaremos as análises realizadas no percurso de nossa investigação, apontando a importância do entrelaçamento entre os discursos e as práticas educativas no coti- 
diano das creches, para que as crianças assumam a condição de sujeitos de direitos nesse espaço institucional. Reafirmamos que essas análises não são conclusivas, pois a pesquisa, por mais intensa que possa ser, constitui-se apenas em respostas parciais da realidade investigada. 


\section{1 \\ Percurso metodológico}

Diferentemente da arte e da poesia que se concebem na inspiração, a pesquisa é um labor artesanal, que se não prescinde da criatividade, se realiza fundamentalmente por uma linguagem fundada em conceitos, proposições, métodos e técnicas, linguagem esta que se constrói com um ritmo próprio e particular.

Minayo, 2000

\section{A discussão metodológica}

Para iniciarmos a apresentação do percurso metodológico da presente pesquisa, gostaríamos de refletir sobre as contribuições do texto de Pedro Benjamim Garcia (1996). O autor, no bojo de suas indagações acerca da relação entre a crise de paradigmas e a educação, faz referência à história de Alice no país das maravilhas, quando a personagem, não sabendo qual caminho percorrer, encontra-se com o gato Cheshire, que afirma à menina que o caminho 
a percorrer está relacionado ao lugar onde queremos chegar. E o autor conclui o diálogo dos personagens afirmando:

Isto não significa que, contrariamente a Alice, tenhamos que saber o caminho, mesmo porque não existe o caminho, mas caminhos, uma pluralidade deles e... desconhecidos. Contudo é necessário escolher algum. E escolher é sempre um risco. Nada nos assegura o resultado do caminho escolhido que, só parcialmente, e muito parcialmente, depende de nós. (Garcia, 1996, p.62)

Assim, a elaboração de uma pesquisa científica é sempre uma opção, reflete escolhas, caminhos e riscos a serem percorridos.

Com base no materialismo dialético histórico de Marx, compreendemos que a metodologia científica deve buscar relações intercausais historicamente constituídas para conhecer a essência e a explicação dos fenômenos.

A compreensão da construção da metodologia científica, à luz do materialismo dialético histórico e da perspectiva histórico-cultural, pode ser caracterizada pelos seguintes aspectos: ${ }^{1}$ o conhecimento é relativo, nunca acabado; existe uma unidade inseparável entre o empírico e o racional, entre o teórico e o prático, entre o quantitativo e o qualitativo, fazendo romper as dicotomias e estabelecendo as inter-relações e as contradições; a seleção dos métodos está aliada à definição do objeto de estudo, e o valor ético da produção científica consiste no respeito à diversidade de conhecimentos.

Portanto, a escolha de determinada metodologia requer a aproximação com o objeto de estudo, excluindo-se a ideia de superioridade de um determinado método ou abordagem.

1. Anotações das aulas do prof. dr. Guilhermo Arias Beatón, na disciplina Construcción del Conocimiento: una metodología desde el materialismo dialéctico e histórico, ministrada no Programa de Pós-Graduação em Serviço Social da Unesp de Franca, no primeiro semestre de 2006. 
Dessa forma, cada método tem suas características, adequando-se às especificidades do problema, dos objetivos e dos propósitos de investigação. $\mathrm{O}$ problema não está em como usar determinado método e sim em ter claro o limite que cada método pode determinar no processo de investigação de uma dada realidade. $\mathrm{O}$ pesquisador precisa ter uma definição concisa do problema de pesquisa, enquanto etapa mais importante do processo de investigação científica, para escolha do método.

Nas Ciências Sociais, a abordagem qualitativa tem sido mais utilizada, principalmente nos estudos culturais, educativos e sociológicos, por proporcionar uma interpretação e análise explicativa do caráter humano e subjetivo.

Conforme Minayo (2000b, p.21), a pesquisa qualitativa trabalha com o universo de significações, aspirações, crenças, valores e atitudes, contribuindo dessa forma para uma compreensão adequada de certos fenômenos sociais de relevância no aspecto subjetivo. Possibilita aos participantes da pesquisa expressarem suas percepções e representações, valorizando o conteúdo apresentado pelos sujeitos.

Já evidenciamos a proximidade com o objeto de estudo na introdução deste trabalho, em especial pelo envolvimento com a questão da educação infantil, quer por nossa trajetória profissional, quer pela formação acadêmica.

O suporte teórico-metodológico para o nosso caminhar foi resultado de um estudo realizado na disciplina de Seminários de Tese, no doutorado, em que nos aproximamos do aporte teórico-metodológico das representações sociais. Apesar de sua complexidade conceitual, há um consenso nas Ciências Sociais de que as representações sociais revelam as ideias, as concepções, percepções e visões de mundo que os atores sociais possuem sobre a realidade social, favorecendo a interação social e a prática social dos indivíduos em uma determinada realidade.

Para Minayo, as representações sociais constituem-se em um importante material para as pesquisas nas Ciências Sociais: 
[...] podemos dizer que as representações sociais enquanto senso comum, ideias, imagens, concepções e visões de mundo que os atores sociais possuem sobre a realidade social, são um material importante para a pesquisa no interior das Ciências Sociais. As representações sociais se manifestam em condutas e chegam a ser institucionalizadas, portanto, devem ser analisadas a partir da compreensão das estruturas e dos comportamentos sociais. (Minayo, 2004, p.173)

A história da teoria das representações sociais iniciou-se com o surgimento da Psicanálise. Sérge Moscovici, ao buscar uma redefinição dos problemas e conceitos da Psicologia Social, por meio do estudo de como a Psicanálise, enquanto disciplina científica, pode ser transferida do domínio dos especialistas para o domínio do público em geral, estabeleceu a teoria das representações sociais. Assim, o conceito de representação social foi criado em 1961 por Moscovici, através do trabalho intitulado La Psychanalyse, son image et son public. A representação social define um cenário interdisciplinar que abrange disciplinas como História, Economia, Antropologia, Semiótica e Psicologia. Porém, é na Psicologia Social que as representações sociais adquirem o estatuto de abordagem e teoria.

Segundo Moscovici, "a representação social é uma modalidade de conhecimento particular que tem por função a elaboração de comportamentos e a comunicação entre indivíduos" (Moscovici, 1978, p.26).

Dotta (2006, p.17), ao referir-se aos postulados de Moscovici, destaca o caráter determinante das representações sociais nos comportamentos dos indivíduos: "Ela reproduz e determina comportamentos, definindo simultaneamente a natureza dos estímulos que cercam e provocam os indivíduos e o significado das respostas a serem dadas".

A autora afirma que Moscovici considera as representações sociais entidades quase tangíveis, visto que "circulam, cruzam-se e e cristalizam continuamente por meio de palavras, gestos e encontros no universo cotidiano" (Dotta, 2006, p.18). 
Para Moscovici, estamos inseridos em uma sociedade pensante, na qual os homens são pensadores ativos que comunicam e produzem suas representações através do processo de interação social.

Na perspectiva psicossociológica de uma sociedade pensante, os indivíduos não são apenas processadores de informações, nem meros "portadores" de ideologias ou crenças coletivas, mas pensadores ativos que, mediante inumeráveis episódios cotidianos de interação social produzem e comunicam incessantemente suas próprias representações e soluções específicas para as questões que se colocam a si mesmos. (Moscovici, 1978, p.28)

Desse modo, as representações sociais podem ser compreendidas como fenômenos essencialmente sociais que, mesmo acessados a partir de seu conteúdo cognitivo, devem ser entendidos em seu contexto de produção, ou seja, com base nas funções simbólicas e ideológicas a que servem e nas formas de comunicação em que circulam.

A pesquisa na abordagem das representações sociais é necessariamente uma pesquisa qualitativa. Os estudos empíricos sobre as representações sociais podem ocorrer mediante o estudo de situações complexas (instituições, comunidades e eventos), aproximando-se das etnografias ou da pesquisa participante, ou focalizando sujeitos, agentes e atores socialmente definidos.

Segundo Dotta (2006, p.41), a teoria das representações sociais constitui-se em um referencial teórico-metodológico, ou seja, configura-se como uma teoria que traz em seu bojo um método. Ao discutir a questão metodológica refere-se a Robert Farr (2000) e Sá (1998). Para o primeiro autor, não há evidências de que haja um método especial a ser empregado nas pesquisas em representação social. O segundo autor chama a atenção para a dificuldade de especificação dos métodos de pesquisa nas representações sociais, o que não significa que todos os métodos possam ser empregados nessa abordagem, destacando os métodos qualitativos, os tratamentos estatísticos correlacionais e o método experimental. 
As estratégias metodológicas para a abordagem do conceito de representações sociais são variadas, dentre elas: entrevistas abertas, semiestruturada, questionários abertos e fechados, escalas como as de diferencial semântico, desenhos e representações gráficas. Pesquisas empíricas apontam o predomínio da presença do método conhecido como análise de conteúdo para o tratamento de dados.

Dotta (2006, p.50) destaca a importância de os sujeitos expressarem-se espontaneamente durante as entrevistas, considerando que a conversação é que molda e anima as representações sociais.

A partir desse aporte teórico-metodológico iniciamos a construção da pesquisa empírica.

\section{O universo e os instrumentais da pesquisa}

As creches pesquisadas localizam-se na cidade de Franca, situada na região nordeste do Estado de São Paulo, aproximadamente a $400 \mathrm{~km}$ da capital. É sede da 14a Região Administrativa do estado, constituída por 23 municípios, e faz fronteira com as cidades paulistas Batatais, Cristais Paulista e Patrocínio Paulista, e com as cidades mineiras de Ibiraci e Claraval.

A população, conforme estimativas do Instituto Brasileiro de Geografia e Estatística (IBGE) de 2007, é de 319.094 habitantes. A população economicamente ativa é de aproximadamente 184.000 habitantes, totalizando perto de $64 \%$ da população. Franca destaca-se como centro de uma das mais importantes regiões produtoras de café, bem como é a maior produtora de calçados do país, para os mercados interno e internacional.

A educação infantil no município é oferecida em creches e pré-escolas. Dados ${ }^{2}$ referentes às instituições municipais e conveniadas demonstram em 2008 o atendimento a 6.650 crianças de 0 a 5 anos e 11 meses. As pré-escolas municipais, no total de 49 instituições,

2. Os dados foram informados por profissionais da Secretaria Municipal de Educação em junho de 2009. 
atendem a 3.961 crianças, na faixa etária de 4 a 5 anos e 11 meses, enquanto as creches conveniadas e municipais, no total de 34 instituições, atendem a 3.021 crianças de 0 a 5 anos e 11 meses.

\section{A seleção do universo de pesquisa}

Para selecionarmos o universo desta pesquisa, estabelecemos o primeiro contato com a Secretaria Municipal de Educação de Franca, em junho de 2008, para o levantamento das creches existentes na cidade. A maioria das creches é conveniada com o poder público municipal, porém a sua gestão fica sob responsabilidade de entidades filantrópicas, ${ }^{3}$ quase sempre ligadas a grupos religiosos, fato que remete aos primórdios do histórico dessas instituições, caracterizando a fase do atendimento assistencialista marcada pela filantropia.

O quadro na época totalizava 31 instituições; destas, duas eram municipais, 27 conveniadas, uma particular, com convênio diferenciado com a Prefeitura, e uma pública, porém não conveniada com o poder público municipal.

Embora a LDB defina creche como instituição destinada ao atendimento das crianças de 0 a 3 anos, no município de Franca essa nomenclatura é utilizada para todas as instituições que atendem a faixa etária de 0 a 6 anos, o que deverá ser modificado a partir de 2010, quando o convênio será estabelecido exclusivamente para a faixa etária de 0 a 3 anos. Esse dado é reflexo das reformas nas políticas educacionais brasileiras, que, dentre tantas mudanças, trouxe o ingresso das crianças a partir de seis anos no ensino fundamental.

3. Segundo Izumi (2005), a primeira creche em Franca foi fundada em 1945. No período de 1956 a 1987 foi lenta a expansão do atendimento e após 1988, com a Constituição Federal e com o reconhecimento legal da creche como direito da criança, são fundadas $50 \%$ das instituições existentes no município. Cabe ressaltar que em 1989, data em que realizamos a nossa primeira pesquisa nas creches de Franca, o quadro era de 18 instituições. Considerando o número existente em 2008, podemos afirmar que houve um aumento de quase $70 \%$ em duas décadas. 
Assim, a pré-escola passa a atender a faixa etária de 4 aos 5 anos e 11 meses em período parcial, e as creches mantêm o atendimento em período integral.

Para delimitação do universo da pesquisa selecionamos as instituições conveniadas que atendessem em seu quadro crianças na faixa etária de 0 a 3 anos e 11 meses de idade, ${ }^{4}$ o que representou 13 instituições, conforme demonstrado no Quadro 1.

No mesmo ano iniciamos a nossa participação nas reuniões mensais da Secretaria de Educação para formação continuada dos coordenadores de creches. Além da pesquisa, nosso interesse também foi em razão de exercermos a função de coordenação em uma creche, embora não conveniada com o poder público municipal, e, portanto, não participante do universo desta pesquisa. A participação neste projeto de formação continuada permitiu uma proximidade com a realidade a ser investigada, e a possibilidade de construção de conhecimentos acerca da educação infantil e troca de experiências profissionais.

Para iniciarmos a pesquisa, aplicamos um questionário com questões abertas às educadoras das creches. $\mathrm{O}$ emprego desse instrumental, nessa etapa da pesquisa, justificou-se pela possibilidade de permitir o acesso a um número maior de sujeitos (Gil, 1999, p.128), além de ser um importante instrumento utilizado nas representações sociais e nas pesquisas qualitativas. A entrega dos questionários às coordenadoras das creches foi realizada em uma das reuniões de formação no segundo semestre do ano de 2008, sendo solicitado que fossem preenchidos pelas educadoras das instituições. Posteriormente, agendamos por telefone o recolhimento dos questionários e pessoalmente fomos recolhê-los nas creches. Dos 72 questionários obtivemos o retorno de 53. Somente uma das instituições não participou da pesquisa, pois a coordenadora não

4. A delimitação da faixa etária justifica-se em razão de a LDB estabelecer como creche a instituição destinada ao atendimento educacional de crianças de 0 a 3 anos e 11 meses. 


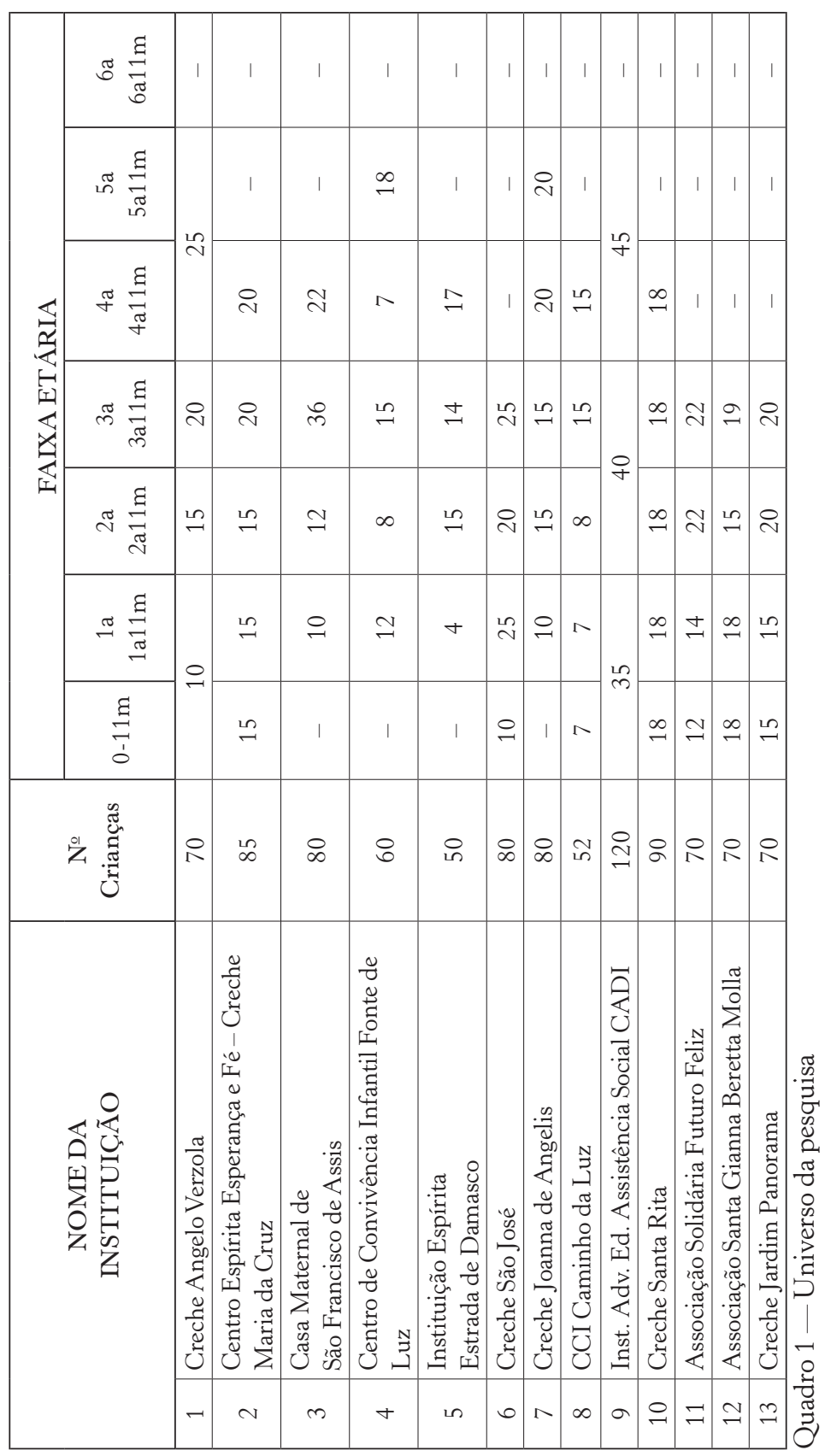


repassou o questionário às educadoras e nas três vezes que retornamos à instituição não a encontramos.

Depois de tabularmos os dados dos questionários, percebemos a necessidade de aprofundarmos algumas categorias de análise e optamos pela realização da entrevista semiestruturada.

A técnica de entrevista semiestruturada permite ao entrevistado contribuir no processo de investigação com liberdade e espontaneidade, sem perder a objetividade.

No entender de Triviños (1987, p.146), a entrevista semiestruturada é

[...] aquela que parte de certos conhecimentos básicos apoiados em teorias e hipóteses, que interessam à pesquisa, e que, em seguida oferecem amplo campo de interrogativas, fruto de novas hipóteses que vão surgindo à medida que se recebem as respostas do informante. Desta forma, o informante seguindo espontaneamente a linha de seu pensamento e de suas experiências dentro do foco principal colocado pelo investigador, começa a participar do conteúdo de pesquisa.

Os sujeitos entrevistados foram escolhidos pelo critério de tempo de exercício profissional, representando 10\% do total dos participantes do questionário. Assim, selecionamos cinco educadoras, sendo três com experiências entre um a três anos na educação infantil e outras duas acima de três anos.

Para aplicação das entrevistas, selecionamos três instituições, e o critério de escolha foi a localização em áreas diferentes da cidade. A escolha da educadora a ser entrevistada foi feita pela coordenadora da instituição, desde que correspondesse ao tempo de experiência profissional acima descrito.

Para análise dos dados também foi empregada a técnica de análise de conteúdo, que, segundo Bardin (2000, p.28), "aparece como um conjunto de técnicas de análise das comunicações que utiliza procedimentos sistemáticos e objectivos de descrição do conteúdo das mensagens". 
Minayo (2000b, p.74-5), destaca as funções da técnica de análise de conteúdo nas pesquisas quantitativas e qualitativas referentes à verificação das hipóteses ou questões da pesquisa e quanto à descoberta do que está por trás dos conteúdos manifestados pelos sujeitos da pesquisa. Segundo a autora, a análise de conteúdo abrange as fases de pré-análise, exploração do material e o tratamento e interpretação dos resultados obtidos.

No intuito de compreendermos melhor algumas questões manifestadas nas entrevistas, assim como a política de atendimento que rege as instituições pesquisadas, realizamos entrevistas com duas profissionais da Secretaria Municipal de Educação que fazem parte da equipe de gestão das creches.

Consideramos pertinente a discussão de alguns dados das entrevistas porque possibilitam maior visibilidade do universo da pesquisa.

O primeiro ponto diz respeito ao percentual do atendimento das creches, que aumentou ${ }^{5}$ significativamente após o ano de 2007, como podemos confirmar no Quadro 2. Esse período coincide com as mudanças na Política de Educação Infantil propagadas pelo Ministério da Educação e Cultura (MEC), e pela aprovação do Fundo de Manutenção e Desenvolvimento da Educação Básica e Valorização dos Profissionais da Educação (Fundeb), ${ }^{6}$ que estabeleceu, dentre tantas medidas, o repasse de verbas para os municípios destinadas à educação infantil.

Conforme os dados disponibilizados no Quadro 2, temos registrado o aumento de dezessete instituições conveniadas construídas pelo poder público municipal, além de sete creches ampliadas e duas reformadas, a partir de 2007, na cidade de Franca.

5. Segundo informações de uma das profissionais da Secretaria de Educação do Município, a meta do atual governo municipal é a de ampliar para 50 o número de creches na cidade até 2012.

6. O Fundeb, regulamentado pela Lei n. 11.494/2007, constitui-se em um fundo de natureza contábil destinado ao financiamento da educação básica. O repasse dos recursos financeiros tem como base o número de alunos matriculados em cada nível de ensino, conforme dados do censo escolar. 
Quadro 2 - Número de crianças atendidas nas creches conveniadas e municipais de 2004 a 2008

\begin{tabular}{|c|c|c|c|c|c|c|}
\hline $\begin{array}{l}\text { N. de } \\
\text { ordem }\end{array}$ & Instituição & 2004 & 2005 & 2006 & 2007 & 2008 \\
\hline 1 & Creche Ângelo Verzola & 70 & 70 & 70 & 70 & 70 \\
\hline 2 & $\begin{array}{l}\text { Centro Espírita Esperança e Fé } \\
\text { Maria da Cruz }\end{array}$ & 70 & $* 85$ & 85 & 85 & *95 \\
\hline 3 & Casa Maternal de Miramontes & 35 & $* 50$ & 50 & 50 & 50 \\
\hline 4 & $\begin{array}{l}\text { Casa Maternal São Francisco de } \\
\text { Assis }\end{array}$ & 80 & 80 & 80 & 80 & 80 \\
\hline 5 & $\begin{array}{l}\text { Centro de Convivência Infantil } \\
\text { Sagrada Família }\end{array}$ & 55 & 55 & $* 65$ & 65 & 65 \\
\hline 6 & Creche Bom Pastor & 70 & *100 & $* 150$ & 150 & 150 \\
\hline 7 & Creche Eurípedes Barsanulfo & 40 & 40 & 40 & $* 55$ & 55 \\
\hline 8 & Creche Jardim das Acácias & 55 & 55 & $* 60$ & 60 & 60 \\
\hline 9 & $\begin{array}{l}\text { Creche Nossa Senhora } \\
\text { Aparecida }\end{array}$ & 130 & 130 & 130 & 130 & 130 \\
\hline 10 & $\begin{array}{l}\text { Creche Nossa Senhora das } \\
\text { Graças }\end{array}$ & 50 & 50 & 50 & 50 & *85 \\
\hline 11 & $\begin{array}{l}\text { Centro de Convivência Infantil } \\
\text { Fonte de Luz }\end{array}$ & 60 & 60 & 60 & 60 & 60 \\
\hline 12 & $\begin{array}{l}\text { Associação Metodista de } \\
\text { Assistência Social - } \\
\text { Creche Vinde a Mim os } \\
\text { Pequeninos }\end{array}$ & 55 & *75 & 75 & 75 & 75 \\
\hline 13 & Creche Estrada de Damasco & 50 & 50 & 50 & 50 & 50 \\
\hline 14 & Infacape & 105 & *110 & 110 & 110 & 110 \\
\hline 15 & $\begin{array}{l}\text { Associação Assistencial } \\
\text { Presbiteriana } \\
\text { Bom Samaritano }\end{array}$ & 100 & 100 & 100 & 100 & *105 \\
\hline 16 & Creche São José & 80 & 80 & 80 & 80 & 80 \\
\hline 17 & Creche Frei José Luiz Igea Sainz & 60 & 60 & 60 & 60 & 60 \\
\hline 18 & $\begin{array}{l}\text { Fundação Educandário } \\
\text { Pestalozzi }\end{array}$ & 100 & *103 & *120 & \#105 & *110 \\
\hline 19 & Sociedade Espírita Veneranda & 25 & $* 45$ & $* 50$ & 50 & 50 \\
\hline 20 & Pastoral do Menor e Família & 25 & 25 & 25 & 25 & 25 \\
\hline 21 & $\begin{array}{l}\text { Instituição Espírita Joanna de } \\
\text { Angelis }\end{array}$ & 80 & 80 & 80 & 80 & 80 \\
\hline 22 & Ação Social Caminho da Luz & 52 & 52 & 52 & 52 & 52 \\
\hline 23 & $\begin{array}{l}\text { Instituição Paulista Adventista } \\
\text { de Educação e Assistência Social } \\
\text { - ADRA - CADE }\end{array}$ & 70 & 70 & *84 & $* 85$ & *120 \\
\hline
\end{tabular}


(cont.)

\begin{tabular}{|c|l|r|r|r|r|r|}
\hline $\begin{array}{c}\text { N. de } \\
\text { ordem }\end{array}$ & \multicolumn{1}{|c|}{ Instituição } & 2004 & 2005 & 2006 & 2007 & 2008 \\
\hline 24 & $\begin{array}{l}\text { Creche Fides et Caritas Santa } \\
\text { Rita }\end{array}$ & 0 & $* 70$ & $* 90$ & 90 & 90 \\
\hline 25 & $\begin{array}{l}\text { Associação Solidária Futuro } \\
\text { Feliz - Recanto Elimar }\end{array}$ & 0 & 0 & 0 & $* 70$ & 70 \\
\hline 26 & $\begin{array}{l}\text { Associação Santa Gianna - Jd. } \\
\text { Luíza II }\end{array}$ & 0 & 0 & 0 & $* 70$ & 70 \\
\hline 27 & Creche Jardim Panorama & 0 & 0 & 0 & 0 & $* 70$ \\
\hline 28 & CCI Servidor Público Municipal & 110 & $* 121$ & 121 & $* 135$ & $\# 132$ \\
\hline 29 & Creche do Distrito Industrial & 0 & 0 & 0 & 0 & $* 236$ \\
\hline 30 & Creche do Aeroporto I & 0 & 0 & 0 & 0 & $* 110$ \\
\hline 31 & Creche do Chico Neca & 0 & 0 & 0 & 0 & $* 110$ \\
\hline 32 & Creche do Leporace II & 0 & 0 & 0 & 0 & $* 110$ \\
\hline 33 & Creche do Jardim Aeroporto II & 0 & 0 & 0 & 0 & $* 70$ \\
\hline 34 & Creche do Jardim Noêmia & 0 & 0 & 0 & 0 & $* 110$ \\
\hline 35 & Creche Parque das Esmeraldas & 0 & 0 & 0 & 0 & $* 110$ \\
\hline 36 & Creche da Vila Santa Luzia & 0 & 0 & 0 & 0 & $* 70$ \\
\hline 37 & Creche do Jardim Cambuí & 0 & 0 & 0 & 0 & $* 110$ \\
\hline 38 & Creche do Jardim Luíza I & 0 & 0 & 0 & 0 & $* 110$ \\
\hline 39 & Creche do Jardim Júlio D’Elia & 0 & 0 & 0 & 0 & $* 110$ \\
\hline 40 & Creche do Jardim Palestina & 0 & 0 & 0 & 0 & $* 110$ \\
\hline 41 & $\begin{array}{l}\text { Creche do J. Pulicano/ } \\
\text { Proinfância }\end{array}$ & 0 & 0 & 0 & 0 & $* 140$ \\
\hline TOTAL - CONVENIADAS & 1.627 & 1.816 & 1.937 & 2.092 & 3.755 \\
\hline 42 & Núcleo de EI - CAIC & 220 & $\# 216$ & $\# 174$ & $\# 151$ & $* 156$ \\
\hline 43 & $\begin{array}{l}\text { Antonieta C. do Couto Rosa } \\
\text { - Aeroporto III }\end{array}$ & 0 & 0 & Conv. & PMF & PMF \\
\hline TOTAL GERAL & 1.847 & 2.032 & 2.161 & 2.293 & 3.961 \\
\hline & & 0 & 50 & 50 \\
\hline
\end{tabular}

Fonte: Secretaria Municipal de Educação da Prefeitura Municipal de Franca.

Dados complementares fornecidos pela profissional da equipe da gestão das creches:

*Aumento do número de vagas.

\# Diminuição do número de vagas.

Novas vagas: 2005: 185; 2006: 129; 2007: 132 e 2008: 1.668 .

No ano de 2008 foram atendidas 3.021 crianças nas creches.

Observação: as creches presentes nos item 33 a 41 iniciarão o atendimento a partir do segundo semestre de 2009, totalizando 940 novas vagas e o atendimento total será de 3.961 crianças. 
A Secretaria Municipal de Educação assumiu a gestão das creches a partir de 1998, após dois anos da promulgação da LDB que, ao reconhecer as creches como instituições de educação infantil, estabeleceu que as mesmas deveriam passar do âmbito da Assistência Social para a Educação.

O trabalho da equipe de gestão de creches da Secretaria Municipal de Franca implica a administração do convênio da Prefeitura com as creches, como ainda a formação continuada dos profissionais das instituições, envolvendo desde a diretoria ao pessoal de apoio. Para esse trabalho, a Secretaria de Educação mantém uma equipe de profissionais formada por 22 pedagogas, uma fonoaudióloga e três assistentes sociais. Do total das pedagogas, 21 têm atuação direta nas creches, com carga horária de 40 horas semanais, sendo que cada uma fica responsável, em média, por duas creches.

O trabalho de formação continuada é realizado mensalmente ${ }^{7} \mathrm{e}$ coordenado por uma pedagoga e pelas assistentes sociais. As reuniões com as educadoras e equipe de apoio acontecem nas instituições, com a coordenação da pedagoga responsável pela instituição. A coordenação e os dirigentes recebem a formação continuada na Secretaria Municipal, onde os temas abordados dizem respeito à infância e à educação infantil. A contribuição do trabalho de formação continuada desenvolvido por essa equipe técnica foi muito citado pelas educadoras durante as entrevistas, sendo destacado como aspecto facilitador do trabalho e sistematizador da organização das práticas pedagógicas nas instituições.

O convênio das instituições com o poder público é administrado pelas assistentes sociais da equipe de gestão. Refere-se ao repasse de subvenção para a folha de pagamento de pessoal e encargos e aquisição de materiais didáticos e pedagógicos. Além desses re-

7. Para a realização da formação continuada, as creches são fechadas todas as primeiras terças-feiras do mês em período integral. A formação dos coordenadores e dirigentes realizada na Secretaria Municipal acontece em período parcial e no outro período os trabalhos de formação prosseguem nas instituições com toda a equipe. 
cursos, a Prefeitura repassa, mensalmente, a doação de gêneros alimentícios não perecíveis e, semanalmente, verduras, leite, pães e carnes. As despesas de utilidade pública (luz e água) são custeadas pelo poder público. Segundo informações de uma das profissionais entrevistadas, desde 2007, as creches são entregues com toda a infraestrutura - mobiliários e equipamentos necessários para a realização de suas atividades.

\section{Os sujeitos da pesquisa}

Os sujeitos de nossa pesquisa foram as educadoras das creches da cidade de Franca. Embora a LDB estabeleça a nomenclatura de professores de educação infantil para os profissionais que atuam na educação infantil, quer seja nas creches ou pré-escolas, esses profissionais são designados como educadores nas creches de Franca.

A trajetória histórica dos profissionais da infância revela que seu papel social, nas creches e pré-escolas, sempre esteve atrelado ao projeto institucional dessas instituições. Várias denominações já foram empregadas para identificar o papel desses profissionais, dentreelas: babá, pajem, berçarista, recreacionista, auxiliar de desenvolvimento infantil, monitor e, atualmente, professor de educação infantil.

Segundo entrevista concedida por uma das profissionais da equipe de formação continuada das creches da Secretaria Municipal de Educação, o emprego do termo educadora responde a uma questão legal e sindical. ${ }^{8}$ Há presença majoritária das mulheres ocupando a função de educadoras nas creches, confirmando a ideia historicamente construída de que a educação e cuidados das crianças pequenas é responsabilidade da mulher.

A realidade de grande parte das instituições de atendimento às crianças de 0 a 6 anos em nosso país revela um quadro de profissio-

8. As educadoras das creches são filiadas ao Sindicato dos Empregados em Empresas de Asseio e Conservação, Empregados e Edifícios e Condôminos e Empregados em Turismo e Hospitalidade de Franca e Região. 
nais leigos, sem formação adequada para o desempenho da função, com mínima formação escolar e em condições precárias de trabalho, no que se refere a remuneração, formação em serviço e plano de carreira profissional.

A LDB, no artigo 62, dispõe que a formação do profissional de educação infantil se faça em nível superior ou médio:

A formação de docentes para atuar na educação básica, far-se-á em nível superior, em curso de licenciatura, de graduação plena, em universidades e institutos superiores de educação admitida como formação mínima para o exercício do magistério na educação infantil e nas quatro primeiras séries do ensino fundamental, a oferecida em nível médio, na modalidade Normal.

A realidade da formação das educadoras é bastante satisfatória, visto que dezesseis educadoras, representando o percentual de $30 \%$ das entrevistadas, têm o nível superior completo; a mesma proporção, ou seja, 30\%, está cursando o nível superior; dezoito concluíram o nível médio, ou seja, 34\% das entrevistadas e, dentre estas, dezesseis cursaram o Magistério. Apenas 1,8\%, o que representa uma educadora, tem somente o ensino fundamental e, em contrapartida, duas, no total de 3,7\%, concluíram a pós-graduação.

$\mathrm{Na}$ Tabela 1 podemos caracterizar a escolaridade dos sujeitos da pesquisa.

Podemos verificar que a formação em nível superior é majoritariamente no curso de Pedagogia, o que responde a uma exigência da LDB para a docência na educação infantil.

Segundo informações da profissional da equipe de gestão das creches, a formação no Magistério (nível médio) ou na Pedagogia (nível superior) é uma das exigências para a contratação dessas profissionais pelas instituições.

O tempo de exercício profissional, como podemos constatar na Tabela 2, para a maioria das entrevistadas é de um ano, totalizando $34 \%$ das educadoras. Em entrevista, a profissional da equipe de 
Tabela 1 - Escolaridade das educadoras

\begin{tabular}{|l|c|c|c|}
\hline \multicolumn{1}{|c|}{ Escolaridade } & \multicolumn{2}{c|}{ Total de sujeitos } & Porcentagem \\
\hline Ensino Fundamental & \multicolumn{2}{|c|}{1} & $2 \%$ \\
\hline Ensino Médio & \multicolumn{2}{|c|}{2} & $4 \%$ \\
\hline Magistério & \multicolumn{2}{|c|}{16} & $30 \%$ \\
\hline Ensino Superior Completo & Pedagogia & Outros & $30 \%$ \\
\hline & 14 & 2 & $30 \%$ \\
\hline Ensino Superior Incompleto & Pedagogia & Outros & $4 \%$ \\
\hline & 15 & 1 & $100 \%$ \\
\hline Pós-Graduação & \multicolumn{2}{|c|}{2} & \\
\hline Total & \multicolumn{2}{|c|}{53} & \\
\hline
\end{tabular}

formação continuada da Secretaria Municipal de Educação revelou ser grande a rotatividade desses profissionais nas instituições, em virtude, especialmente, das condições salariais. ${ }^{9}$

Em relação à experiência profissional, conforme os dados da Tabela 3, podemos constatar que $56,6 \%$ dos sujeitos da pesquisa, ou seja, trinta educadoras, tinham experiências anteriores na educação infantil. Doze, ou seja, 22,6\% das educadoras vinham de experiências na área do comércio; oito, totalizando $15,1 \%$, não tinham nenhuma experiência profissional. As demais apresentaram experiências em outros níveis de ensino, ou seja, duas, no total de $3,8 \%$, atuavam no ensino fundamental, e uma, representando $1,9 \%$, atuava na educação de adultos.

9. Conforme informações de uma coordenadora de creche, o salário das educadoras, contratadas em regime de CLT por 40 horas semanais, é de RS 700,00. O piso estabelecido pelo Sindicato da categoria é de $\mathrm{R} \$ 548,00$, porém, com o aumento da subvenção municipal, em 2009, foi realizado o reajuste dos salários das educadoras em todas as creches. 
Tabela 2 - Tempo de exercício profissional na educação infantil

\begin{tabular}{|l|c|c|}
\hline $\begin{array}{c}\text { Tempo de exercício } \\
\text { profissional na } \\
\text { educação infantil }\end{array}$ & Total de sujeitos & Porcentagem \\
\hline Até 1 ano & 18 & $34 \%$ \\
\hline 2 a 3 anos & 15 & $28 \%$ \\
\hline 4 a 6 anos & 9 & $17 \%$ \\
\hline 8 a 10 anos & 4 & $8 \%$ \\
\hline Acima de 10 anos & 7 & $13 \%$ \\
\hline Total & 53 & $100 \%$ \\
\hline
\end{tabular}

Tabela 3 - Experiência profissional

\begin{tabular}{|l|c|c|}
\hline Experiência profissional & Total de sujeitos & Porcentagem \\
\hline Educação infantil & 30 & $56,6 \%$ \\
\hline Comércio & 12 & $22,6 \%$ \\
\hline Nenhuma experiência & 8 & $15,1 \%$ \\
\hline Ensino fundamental & 2 & $3,8 \%$ \\
\hline Educação de adultos & 1 & $1,9 \%$ \\
\hline Total & 53 & $100 \%$ \\
\hline
\end{tabular}

Conforme os dados apresentados, constatamos que o quadro atual das educadoras das creches é satisfatório no que se refere a formação acadêmica e experiência profissional. Pesquisa realizada nos estados de Ceará, Pernambuco, Minas Gerais e Rio Grande do Sul, de acordo com a Consulta sobre a Qualidade na Educação Infantil (2006), demonstrou o baixo nível de escolaridade dos profissionais dessa área, sendo que apenas $21 \%$ dos entrevistados possuíam curso superior e $10 \%$ apresentavam apenas o ensino fundamental incompleto. 


\section{2}

\section{TECENDO OS FIOS DA INFÂNCIA}

As crianças, todas as crianças, transportam o peso da sociedade que os adultos lhes legam, mas fazem-no com a leveza da renovação e o sentido de que tudo é de novo possível. Sarmento, 2004

\section{Infâncias e crianças}

A infância tem-se constituído em um campo emergente de estudos para várias áreas do saber, porém focados em divergentes abordagens, enfoques e métodos, os quais determinaram distintas imagens sociais sobre as crianças.

Segundo Sarmento (2007, p.26), as concepções construídas historicamente sobre a infância, baseadas numa perspectiva adultocêntrica, tanto esclarecem como ocultam a realidade social e cultural das crianças sendo, portanto, necessária a ruptura com o modelo epistemológico sobre a infância até então instituído. 
O autor afirma ser recente o interesse histórico pela infância, sendo predominante no quadro teórico sua concepção como construção social, ideia esta preconizada pelo historiador francês Philippe Ariès (1986), que apresenta importantes contribuições para o estudo das imagens e concepções da infância ao longo da história, embora seja criticado por alguns autores em razão de sua visão histórica linear e por seus limites metodológicos.

Philippe Ariès realizou seus estudos da iconografia da era medieval à modernidade observando representações da infância na Europa ocidental, especialmente na França, estudos esses que sinalizam a infância como produto da vida moderna, resultante das modificações na estrutura social.

A tese da ausência do sentimento de infância na Antiguidade é relatada pelo autor considerando os altos índices de mortalidade das crianças e a forma de viver indistinta dos adultos manifestada nos trajes, nos brinquedos, na linguagem e em outras situações do cotidiano revelando uma criança que não possuía nenhuma singularidade e não se separava do mundo adulto, sendo, pois, considerada um adulto em miniatura.

Corazza (2002, p.81) considera que a história da infância revela um silêncio histórico, ou seja, uma ausência de problematização sobre essa categoria, não porque as crianças não existissem, mas porque, do período da Antiguidade à Idade Moderna, "não existia este objeto discursivo a que hoje chamamos infância, nem esta figura social e cultural chamada 'criança"'.

Apesar de algumas críticas ${ }^{1}$ serem tecidas à análise iconográfica realizada por Ariès, a sua obra é um marco para entendermos que a infância é uma categoria da modernidade e que não pode ser compreendida fora da história da família e das relações de produção.

Na Idade Média, as crianças pequenas não tinham função social antes de trabalharem, sendo alta a taxa de mortalidade infantil.

1. Corazza, ao abordar o percurso histórico da infância, apresenta o discurso de vários teóricos, inclusive dos que tecem críticas à perspectiva linear retratada por Ariès. Sobre esse assunto, ver Corazza (2002). 
Aquelas que eram pobres, assim que cresciam eram inseridas no mundo do trabalho, sem qualquer diferenciação entre adultos e crianças. As crianças nobres tinham seus educadores e eram vistas como miniaturas dos adultos e deveriam ser educadas para o futuro de transição para a vida adulta.

No século XVI, os adultos, em especial as mulheres, começam a destinar certa atenção às crianças reconhecidas como fonte de distração ou relaxamento, o que Ariès (1986, p.159) chamará de "crianças bibelot", expressando um sentimento de "paparicação" pela infância.

A vida em família, até o século XVII, era vivida em público, ou seja, não havia privacidade de seus membros, até mesmo no tocante à educação das crianças. Tudo ocorria no movimento de uma vida coletiva e as famílias conjugais se diluíam nesse meio. O grupo familiar era eminentemente societário. As funções educativas nesses grupos ficavam a cargo do grupo como um todo e se estendiam desde o processo de socialização das crianças até o ensino formal.

De modo geral, a transmissão de conhecimentos e a aprendizagem de valores e costumes eram garantidas pela participação da criança no trabalho, nos jogos e em outros momentos do cotidiano da vida dos adultos. Com as influências do pensamento dos moralistas e da Igreja, nesse período, as crianças consideradas como criaturas de Deus, dotadas de pureza, inocência e bondade, precisariam ser vigiadas e corrigidas.

Mas, já a partir do século XVIII, lentas transformações começaram a ser operadas no interior das famílias, ocasionando o surgimento do "sentimento de família", fortemente marcado pela necessidade e desejo de privacidade. Começaram a ocorrer mudanças até mesmo quanto ao espaço físico no qual a família vivia:

Esta organização da casa passou a corresponder a uma nova forma de defesa contra o mundo e como uma necessidade de isolamento face ao espaço público: a família começou a se manter à distância da sociedade. Emergiram as noções de intimidade, discrição e isolamento, ao se separar a vida mundana, a vida mate- 
rial e a vida privada, cada uma circunscrita a espaços distintos. (Moreira \& Vasconcelos, 2003, p.169)

Instaura-se o modelo da família burguesa, o qual irá trocar a sociabilidade ampla pelo desejo de intimidade, reduzindo as vivências de formas comunitárias tradicionais.

A intimidade e a vida privada da família moderna propõem novas relações familiares, acompanhadas por mudanças de valores, especialmente em relação à educação das crianças. A criança assume um lugar central na família, pois se antes era cuidada de forma difusa e dispersa pela comunidade em geral, passará a ser responsabilidade dos pais. Ou seja, com o capitalismo e a propriedade privada, a criança passa a ser responsabilidade dos pais e também dona e herdeira das riquezas, misérias e valores sociais.

O modelo de família burguesa vem instituir modificações no contexto familiar, como a divisão e diferenciação de papéis sexuais: o homem passa a ser visto como provedor, devendo, portanto, fazer parte do mundo público, e a mulher, responsável pela casa e educação dos filhos, fazendo parte do mundo privado.

Segundo Moreira \& Vasconcelos (2003, p.169), particularmente no século XVIII, com o desenvolvimento do capitalismo consolida-se a separação entre as esferas pública e privada, cabendo ao Estado a administração da esfera pública e das relações de produção, enquanto a família se responsabilizaria pela esfera privada, pelo espaço doméstico e pela reprodução das condições de sobrevivência.

Nesse período, a criança foi nascendo socialmente, considerada como um ser dependente, frágil, ignorante e vazio, que precisava ser treinado para ser um bom cidadão, cabendo à família a responsabilidade pela sua socialização.

A burguesia faz surgir um novo sentido de família, apresentando o modelo nuclear como hegemônico e trazendo também um novo "sentimento de infância", colocando a criança numa condição diferente do adulto: 
Sentimento de infância não significa o mesmo que afeição pelas crianças; corresponde, na verdade, à consciência da particularidade infantil, ou seja, aquilo que a distingue do adulto e faz com que ela seja considerada como um adulto em potencial, dotada de capacidade de desenvolvimento. (Kramer, 2003, p.17)

Para Gagnebin (1997, p.83), é nesse período que, no Ocidente, se confirma a ideia da noção da infância e o reconhecimento da necessidade de a criança ser tratada diferente do adulto, paralelamente ao "triunfo do individualismo e de seus ideais de felicidade e emancipação".

Nesse novo contexto, a família passa a ter como função básica garantir a sobrevivência física, social e psicológica da prole, favorecendo a manutenção das relações sociais e produtivas do modelo hegemônico capitalista. A responsabilização da educação das crianças à mulher veio acompanhada pelo ideal do amor materno, concebido como natural e instintivo, levando-a a exercer com abnegação e dedicação o papel de mãe.

Um novo sentimento destinado à infância, contrário à paparicação, pautado pelos ideários dos moralistas, fará da infância objeto de estudo, instrução e escolarização.

Assim, as mudanças no interior das famílias e a necessidade de educação das crianças são fatores determinantes para o desenvolvimento do sentimento de infância. A escola ${ }^{2}$ confirma-se enquanto instituição responsável pela separação das crianças e jovens do mundo adulto, por meio de práticas autoritárias e disciplinares em defesa da formação do "futuro cidadão".

Moreira \& Vasconcelos assim descrevem a relação entre a escola e a infância:

2. Importante considerar que o projeto de escolarização do século XVIII destinava-se às crianças e jovens da aristocracia e burguesia, visto que, por muito tempo, as crianças camponesas permaneceram misturadas ao mundo adulto. 
[...] a escola tornou-se uma instituição fundamental na sociedade, quando a infância passou a ser vista como fase dotada de diferença, a ser institucionalizada, separada do restante da sociedade e submetida a um regime disciplinar cada vez mais rigoroso. (Moreira \& Vasconcelos, 2003, p.171)

A história da criança brasileira também acontece no quadro das mudanças societárias, sendo que as múltiplas vivências da infância ocorreram em razão do pertencimento social, racial e de gênero (Gouvêa, 2003, p.13).

Desde a presença dos jesuítas no país, temos a configuração de distintas infâncias direcionadas por diferentes projetos educativos. O projeto salvífico da infância é revelado pelos jesuítas ao conceberem a infância como um momento de "iluminação e revelação". Para as crianças nativas, esse projeto significou submetê-las ao violento processo de aculturação (Priori, 1998, p.15). Não muito diferente foi a história da criança negra escrava, iniciada no trabalho antes mesmo de completar sete anos de idade, enquanto a criança branca, da elite, estava destinada aos estudos.

Dessa forma, a classe social, raça, etnia foram determinantes para múltiplas formas de vivência do universo infantil, não existindo, "portanto a infância enquanto categoria universal, e nem a infância no singular, mas diferentes vivências do ser criança em uma mesma cultura" (Gouvêa, 2003, p.16).

Segundo Sarmento (2005, p.371, grifo do autor), é preciso que se faça uma distinção semântica entre infância e criança, categorias que muitas vezes são apresentadas com o mesmo significado no senso comum:

Por isso a Sociologia da Infância costuma fazer, contra a orientação aglutinante do senso comum, uma distinção semântica e conceptual entre infância, para significar a categoria social do tipo geracional, e criança, referente ao sujeito concreto que integra essa categoria geracional e que, na sua existência, para além 
da pertença de um grupo etário próprio, é sempre um actor social que pertence a uma classe social, a um gênero, etc.

Os conceitos de infância podem apresentar diferentes significados, conforme os referenciais que utilizarmos. A palavra infância evoca um período que se inicia com o nascimento e termina com a puberdade.

O Estatuto da Criança e do Adolescente designa criança toda pessoa até 12 anos de idade incompletos. Pode-se, assim, observar que no quadro legal brasileiro prioriza-se uma definição da criança pelo critério etário e pelo aspecto biológico.

Pinto \& Sarmento (1997, p.15), ao discutirem a respeito do limite etário para a definição do ser criança, destacam a inexistência de um consenso, visto que recentes investigações e estudos têm enfatizado a condição da criança como sujeito de direitos desde a vida intrauterina.

Segundo os autores, as dificuldades quanto ao consenso de limites etários da infância se intensificam quando a discussão se refere ao limite etário para deixar de ser criança. A esse respeito, a Convenção dos Direitos da Criança, 1989, considera criança todo ser humano até 18 anos, estabelecendo o fim da infância no período de conquista dos direitos cívicos, como o direito ao voto.

Os limites da infância encontram respaldos, além do campo legal, nas tradições culturais. Para algumas etnias e culturas, a puberdade é considerada o fim da infância e início da vida adulta. Os níveis ou ciclos de escolaridade também são possíveis fronteiras para demarcação da infância.

No Brasil, a educação das crianças até 6 anos de idade é denominada educação infantil, ao passo que o ensino fundamental, atualmente de nove anos, abrange a faixa etária dos 6 aos 14 anos, idade esta que poderia ser considerada como limite para o indivíduo deixar a sua condição infantil. Considerando que muitas crianças concluem o ensino fundamental com idade superior aos 14 anos, podemos inferir o quanto é arbitrário o critério de escolaridade para definição do limite etário da infância. 
Concluindo a discussão sobre o estabelecimento dos limites para definição da infância, Pinto \& Sarmento (1997, p.17) asseveram:

[...] o estabelecimento desses limites não é uma questão de mera contabilidade jurídica, nem é socialmente indiferente. Pelo contrário é uma questão de disputa política e social, não sendo indiferente ao contexto em que se coloca nem ao espaço ou tempo da sua colocação. Assim "ser criança" varia entre sociedades, culturas e comunidades, pode variar no interior da fratria de uma mesma família e varia de acordo com a estratificação social. Do mesmo modo, varia com a duração histórica e com a definição institucional da infância dominante em cada época.

Podemos compreender que o estabelecimento dos limites da infância é um processo polêmico, contraditório e constitutivo da própria infância enquanto categoria social (Fullgraf, 2001, p.28).

Javeau (2005), ao discutir o conceito polissêmico da infância chama a atenção para o campo semântico dos termos infância, criança e crianças. Segundo o autor, o termo criança remete a uma concepção psicológica, à preocupação com o sujeito criança em si, considerando as suas características individuais.

O autor destaca: "construiu-se um objeto abstrato, a 'criança', destinado a passar por níveis diversos e sucessivos de aquisição de competências, cada um deles constituindo uma etapa na fabricação da personalidade dos indivíduos" (Javeau, 2005, p.382).

Em relação à infância, o autor apresenta a perspectiva demográfica, referindo-se à geração e à faixa etária; por sua vez, o termo crianças relaciona-se ao campo antropológico ou socioantropológico, podendo ser consideradas como "uma população ou conjunto de população com plenos direitos científicos, com seus traços culturais, seus ritos, suas linguagens, suas imagens e ações" (Javeau, 2005, p.385).

Sarmento \& Pinto (1997, p.11, grifo dos autores), ao discutirem as concepções de infância e criança, esclarecem que: 
Com efeito, crianças existiram desde sempre, desde o primeiro ser humano, e a infância como construção social - a propósito da qual se construiu um conjunto de representações sociais e de crenças e para qual se estruturaram dispositivos de socialização e controle que a instituíram como categoria social própria existe desde os séculos XVII e XVIII [...].

Para Kuhlmann Júnior (2001, p.31), a infância é uma condição do ser criança, devendo ser compreendida no contexto das relações sociais:

[...] considerar a infância como uma condição da criança. O conjunto de experiências vividas por elas em diferentes lugares históricos, geográficos e sociais é muito mais do que uma representação dos adultos sobre esta fase da vida. É preciso conhecer as representações da infância e considerar as crianças concretas, localizá-las nas relações sociais, etc., reconhecê-las como produtoras da história.

O termo infância apresenta um caráter genérico, cujo significado resulta das transformações sociais, o que demonstra que a vivência da infância modifica-se conforme os paradigmas do contexto histórico e outras variantes sociais como raça, etnia e condição social. Kramer (2003a, p.19) destaca que a ideia de infância aparece com a sociedade capitalista urbana industrial, à medida que mudam a inserção e o papel social da criança na sociedade.

Kuhlmann Júnior (2001, p.16), referindo-se ao caráter histórico e social do termo infância, afirma: "toda sociedade tem seus sistemas de classes e idade e a cada uma delas é associado um sistema de status e de papel". Para ele, é preciso reconhecer as crianças enquanto sujeitos históricos, ou seja, "é importante perceber que as crianças concretas, na sua materialidade, no seu nascer, no seu viver e no seu morrer, expressam a inevitabilidade da história e nela se fazem presentes, nos seus mais diferentes momentos" (Kuhlmann Júnior, 2001, p.32). 
O autor também considera que a história da infância apresenta um caráter não linear e deve ser contextualizada, aliada à história da assistência, da família e da educação.

\section{Infâncias: na encruzilhada da modernidade e pós-modernidade}

\section{Infância e a condição da criança de "vir a ser"}

Como vimos, o estudo de Ariès pode ser considerado uma das grandes obras para a compreensão das imagens e concepção da infância ao longo da história, reconhecendo a infância como uma construção da modernidade. Ou seja, é com o projeto de modernidade que a infância sai do anonimato, tornando-se objeto de estudo de várias áreas do saber.

A modernidade trouxe consigo o desejo de compreender, explicar e controlar toda a sociedade, marcada pelos fatores da racionalização do homem e da organização do capital.

Enquanto período histórico, tem sua origem no século XVII, no bojo de profundas transformações sociais e culturais. Atingiu seu ápice no século XVIII, com o advento do iluminismo ${ }^{3}$ e com o apogeu da sociedade industrial.

A modernidade configura-se como período histórico que sucede o período medieval, consagrada pelos ideários iluministas de desenvolvimento da ciência objetiva. O divino, a fé e os fenômenos sobrenaturais deixam de compor a base do conhecimento, sendo substituídos pela razão, pela busca da ordem, do progresso e da moralidade.

Conforme Harvey (2008, p.23):

3. O iluminismo refere-se a um movimento intelectual surgido na segunda metade do século XVIII, reconhecido como Século das Luzes, que enfatizava a razão e a ciência como instrumentos para explicar o universo. 
O desenvolvimento de formas racionais de organização social e de modos racionais de pensamento prometia a libertação das irracionalidades do mito, da religião, da superstição, liberação do uso arbitrário do poder, bem como do lado sombrio da nossa própria natureza humana. Somente por meio de tal projeto poderiam as qualidades universais, eternas e imutáveis de toda a humanidade serem reveladas.

O desenvolvimento das ciências e do método científico fortaleceram os ideários do projeto de modernidade na busca de conhecimentos sobre a realidade e o indivíduo pautado pelo uso incondicional da razão. Aliados à razão estavam os preceitos de liberdade e igualdade, propagados pela Revolução Francesa.

Ainda de acordo com Harvey (2008, p.23):

O projeto de modernidade veio à tona durante o século XVIII. Ele implicou em um esforço intelectual extraordinário por parte dos pensadores do iluminismo para desenvolver uma ciência objetiva, uma moralidade, uma lei universal e uma arte autônoma. A ideia era usar o acúmulo de conhecimento gerado por muitos indivíduos que trabalhavam de maneira livre em busca da emancipação do ser humano e do enriquecimento da vida humana.

Para Santos (1997, p.78), é no século XVIII que se dá o cumprimento histórico do conceito de modernidade, período concomitante ao surgimento do capitalismo ${ }^{4}$ como modo de produção dominante na Europa.

Segundo o projeto iluminista, caberia à escola configurar-se como espaço para a transmissão do conhecimento científico e para a formação do cidadão. Em relação às crianças, o projeto escolar

4. Santos (1997), analisa o desenvolvimento do capitalismo em três períodos: capitalismo liberal (século XIX), capitalismo organizado (final do século XIX) e o capitalismo desorganizado (a partir da década de 1960). Para aprofundar o estudo desses períodos do capitalismo, consultar também Harvey (2008). 
deveria prepará-las para a vida adulta e para o mundo produtivo. As influências desses pensamentos determinaram a configuração de teorias pedagógicas como a de John Locke, na qual a criança é reconhecida como uma tábula rasa, como um "vir a ser", devendo ser preenchida de conhecimentos necessários a sua formação enquanto força produtiva. Essa construção social da criança remete à categoria a que Dahlberg, Moss e Pence se referem, a criança como reprodutora do conhecimento, identidade e cultura, reconhecendo a infância como base para o desenvolvimento futuro:

$\mathrm{Na}$ construção da criança como reprodutor de conhecimento, identidade e cultura, a criança pequena é entendida como iniciando a vida sem nada e a partir de nada - como um vaso vazio ou tábula rasa. Pode-se dizer que esta é a criança de Locke. O desafio é fazer que ela fique "pronta para aprender" e "pronta para a escola" na idade do ensino obrigatório. Por isso, durante a primeira infância a criança pequena precisa ser equipada com os conhecimentos, com as habilidades e com os valores culturais dominantes que já estão determinados, socialmente sancionados e prontos para serem administrados - um processo de reprodução ou transmissão - tem também de ser treinada para se adaptar às demandas estabelecidas pelo ensino obrigatório. (Dahlberg, Moss \& Pence, 2003, p.65)

O interesse pela infância propagado pela modernidade inaugura, num certo sentido, a preocupação com a criança e sua formação, porém o objetivo não era a criança em si, mas o adulto de amanhã. Reconhecida como fase da não razão, da imaturidade, as expectativas sobre a infância propagavam um discurso legitimando a infância como uma fase do desenvolvimento humano no qual a criança, ser frágil e dependente do adulto, deveria ser educada e disciplinada para o desenvolvimento pleno de suas faculdades, inclusive da razão.

As vivências da infância nos séculos pré-modernos ocorriam na coletividade, sendo que a socialização e a educação das crianças 
aconteciam por meio de uma ampla rede de sociabilidade na qual, gradualmente, os pequenos seres adquiriam os conhecimentos referentes aos usos, técnicas e costumes de sua comunidade.

Ariès chama a atenção para o fato de que a ausência da consciência da infância não significava que as crianças fossem maltratadas ou desprezadas. Segundo o autor, até o século XVIII pode-se observar um estado de paparicação excessiva às crianças, como se fossem bichinhos de estimação dos adultos.

Na Idade Média, as crianças não apresentavam estatuto social e autonomia existencial, eram consideradas como meros seres biológicos. "Paradoxalmente, embora a história revele a existência das crianças, seres biológicos, desde a Antiguidade, nem sempre houve infância, categoria social de estatuto próprio" (Sarmento, 2004, p.11).

As crianças pertenciam ao universo feminino até que pudessem ser integradas ao mundo adulto, ou seja, quando apresentassem condições para o trabalho, para a participação na guerra ou para a reprodução. Segundo Barbosa (2006, p.75), era predominante, nesse período histórico, uma visão da criança que a considerava rude, fraca de juízo e marcada pelo pecado original, e que, portanto, deveria ser controlada e vigiada pelos adultos.

O surgimento da infância na modernidade apresenta como caráter paradoxal o reconhecimento da criança e a perda da sua liberdade, pois se antes o anonimato permitia uma ampla vivência na coletividade, agora inicia-se o processo de "privatização" de suas vivências, seja na família, seja na escola. Paralelamente à segregação das crianças do mundo adulto, são desenvolvidos novos sentimentos em relação às crianças associados à pureza, ingenuidade e fragilidade. Barbosa (2006, p.76-7) destaca que, junto ao novo sentimento de infância, são inauguradas novas práticas e teorias para governá-la.

O reconhecimento da infância enquanto etapa do desenvolvimento humano, nos séculos XIX e XX, faz surgir a infância científica, com a propagação de conhecimentos construídos por várias 
áreas do saber, o que determinará um conjunto de teorias e práticas a serem desenvolvidas para cuidar dessa categoria. São divulgadas normas de higiene e cuidados com as crianças, investe-se em campanhas de amamentação, criam-se instituições de atendimento, como as creches e jardins da infância, enfim, cria-se o que Barbosa (2006, p.77) denomina de infância atendida. A autora alerta que esses saberes e instituições destinavam-se à criança burguesa e que outras infâncias coexistiam ao mesmo tempo, ou seja, a criança abandonada nos orfanatos, nas rodas de expostos, a criança explorada nas fábricas ou, ainda, privada de condições dignas de existência.

O conjunto desses saberes ${ }^{5}$ influenciou as representações sociais sobre as crianças incorporadas ao imaginário coletivo. De acordo com Sarmento (2004, p.12), esses saberes prescrevem padrões de "normalidade", ou seja, conhecimentos referentes ao desenvolvimento das crianças, conforme alguns padrões que orientarão as famílias e as instituições nos cuidados e educação das crianças. Conforme o autor, esses saberes pautam-se por duas ideias conflituais da infância:

Referimo-nos às concepções antagônicas rosseaunianas e montaigneanas sobre a criança, ao construtivismo e ao comportamento, às pedagogias centradas no prazer de aprender e às pedagogias centradas no dever do esforço, às pulsões libertadoras e aos estímulos controladores, em suma às ideias da criança-anjo, natural, inocente e bela e a criança demônio, rebelde, caprichosa e disparata. (Sarmento, 2004, p.13)

Dentre os saberes científicos produzidos sobre a infância, podem-se destacar as influências da Psicologia do Desenvolvi-

5. Segundo Barbosa (2006, p.73), os saberes científicos sobre a infância foram produzidos inicialmente pela Biologia, Psicologia e Medicina e somente no século XX tornou-se objeto de estudo da História e da Sociologia. 
mento, ao estabelecer estágios universais do desenvolvimento infantil, sobretudo nas práticas pedagógicas.

Dahlberg, Moss \& Pence (2003, p.53) explicitam as influências da Psicologia do Desenvolvimento na construção do conhecimento sobre a infância:

[...] a Psicologia do Desenvolvimento pode ser vista como um discurso que, além de contribuir para a construção de nossas imagens das crianças e para o nosso entendimento das suas necessidades, contribuiu para a construção e para a constituição de toda a paisagem da infância.

Outros fatores aliados aos saberes científicos sobre a infância contribuíram para a institucionalização da infância na modernidade, dentre eles a institucionalização da escola pública, o sentimento de cuidado e proteção das famílias e a promoção da administração simbólica da infância, configurando uma infância global (Sarmento, 2004, p.12).

Dentre esses fatores, Sarmento (2004, p.13) considera como primeiro e decisivo a criação de instâncias públicas de socialização das crianças com a institucionalização da escola pública, a qual irá configurar o "ofício de aluno" como componente essencial do "ofício de criança". Assim, será na escola que as crianças se apropriarão dos saberes, normas e valores instituídos como dominantes na sociedade.

Para Sarmento (2004, p.13), a modernidade desenvolveu um conjunto de procedimentos configuradores da administração simbólica da infância, os quais estabelecem normas, atitudes e prescrição, nem sempre escritos ou formalizados, que condicionam e direcionam a vida das crianças em sociedade. 


\section{Infância e condição da criança como sujeito de direitos}

Segundo Dahlberg, Moss \& Pence (2003, p.78), novas construções ${ }^{6}$ sobre a infância têm sido elaboradas, conjugadas ao desenvolvimento de vários fatores sociais, econômicos e científicos, em especial aos relacionados às perspectivas construcionistas e pós-modernistas na Filosofia, Sociologia e Psicologia. Os autores destacam que, para a perspectiva pós-moderna, não existe a "criança" e a "infância", visto que "há muitas crianças e muitas infâncias, cada uma construída por nossos 'entendimentos da infância e do que as crianças são e devem ser"' (Dahlberg, Moss \& Pence, 2003, p.63).

Para compreendermos a relação da infância na pós-modernidade, vamos discutir a princípio o seu conceito.

Santos (1997, p.76-7) assim discorre sobre o paradigma da pós-modernidade:

O paradigma cultural da modernidade constitui-se antes de o modo de produção capitalista se ter tornado dominante e extinguir-se-á antes de este último deixar de ser dominante. A sua extinção é complexa porque é em parte um processo de superação e em parte um processo de obsolescência. É superação na medida em que a modernidade cumpriu algumas das suas promessas e, de resto, cumpriu-as em excesso. É obsolescência na medida em que a modernidade está irremediavelmente incapacitada de cumprir outras das suas promessas. Tanto o excesso no cumprimento de algumas das promessas como o déficit no cumprimento de outras são responsáveis pela situação presente, que se apresenta superficialmente como de vazio ou de crise, mas que é, a nível mais profundo, uma situação de transição. Como todas as transições são simultaneamente semicegas e semi-invisíveis, não é possível nomear adequadamente a presente situação. Por esta razão lhe tem sido dado o nome ina-

6. Os autores analisam as mudanças nas construções da infância na Europa, Estados Unidos e países escandinavos, destacando a relação entre o Estado e as famílias nas mudanças das políticas de atendimento à infância. 
dequado de pós-modernidade. Mas, à falta de melhor, é um nome autêntico na sua inadequação.

$\mathrm{O}$ autor argumenta a relação contraditória e dialética entre a modernidade e a pós-modernidade: "A relação entre o moderno é, pois, uma relação contraditória. Não é de ruptura total como querem alguns, nem de linear continuidade como querem outros. É uma situação de transição em que há momentos de ruptura e momentos de continuidade" (Santos, 1997, p.103).

Dahlberg, Moss \& Pence (2003, p.41) também destacam que, apesar das diferentes perspectivas e valores propagados pela modernidade e pós-modernidade, não se pode inferir uma completa oposição e ruptura entre ambas.

O projeto de pós-modernidade, surgido a partir da década de 1960 , vem questionar o conhecimento absoluto propagado pelo projeto iluminista, "reconhecendo a incerteza, a complexidade, a diversidade, a não linearidade, a subjetividade, as perspectivas múltiplas e as especificidades temporais e espaciais" (Dahlberg, Moss \& Pence, 2003, p.37).

Nessa perspectiva não há conhecimento nem verdades absolutas. O conhecimento e o mundo são socialmente construídos, sendo, portanto, provisórios e ilimitados, o que remete à ideia do filósofo Heráclito, a de que pela segunda vez que você pula na água, você não pula na mesma água.

Recorreremos a Libâneo (1997, p.144-5) para sintetizar algumas das características da condição pós-moderna. $\mathrm{O}$ autor elabora as suas considerações destacando os aspectos filosóficos, econômicos, políticos e culturais que configuram o pós-modernismo.

Em relação ao aspecto filosófico, o ponto central do pós-modernismo é a rejeição às teorias totalizantes e a afirmação de categorias universais no âmbito da ideologia, das ciências e da religião.

Quanto ao aspecto econômico, são ressaltadas as mudanças no sistema produtivo e no mundo do trabalho consequentes das transformações técnico-científicas, o que se refletirá em novas exigências para uma mão de obra cada vez mais qualificada. 
A redução da crença moderna no Estado-nação e na prática política convencional são as principais evidências da pós-modernidade no campo político, ao passo que no campo cultural podem-se destacar as mudanças nas formas de produção, circulação e consumo da cultura: "há uma proliferação de significados, gerando uma sociedade em que imperam as simulações, num mundo de imagens e fantasias eletrônicas" (Libâneo, 1997, p.145).

Para Sarmento (2004, p.14-5), a condição elencada como pós-modernidade é referida como segunda modernidade, caracterizada por um quadro complexo de rupturas:

A segunda modernidade caracteriza-se por um conjunto associado e complexo de rupturas sociais, nomeadamente a substituição de uma economia predominantemente industrial por uma economia de serviços, a criação de dispositivos de mercado à escala universal, a deslocalização de empresas, a ruptura do sistema de equilíbrio de terror entre dois blocos, com a crise dos países socialistas do Leste Europeu e o fim dos regimes comunistas, a afirmação dos EUA como única potência hegemônica, a conclusão do processo de descolonização dos países africanos, a emergência de uma situação ambiental crítica, as rupturas no mercado de trabalho pela subida das taxas de desemprego, a crise de subsistência do Estado-Providência, a crescente presença e reclamação na cena internacional de movimentos sociais e protagonistas divergentes das instâncias hegemônicas, a afirmação radical de culturas não ocidentais, nomeadamente de inspiração religiosa, etc.

Na visão do autor, um dos traços mais marcantes da infância na segunda modernidade é a mudança e pluralização de suas identidades, em virtude do processo de globalização. Embora tenhamos diferenças e desigualdades marcantes na vivência da infância em todo o mundo, os impactos da globalização nessa categoria geracional contribuíram para a disseminação da ideia da existência de uma só infância mundial. Os efeitos da globalização da infância são 
resultantes de processos econômicos, políticos, culturais e sociais, conforme esclarece Sarmento (2001, p.15):

No entanto, a globalização da infância é hoje a resultante de processos políticos (por exemplo, por efeito da regulação introduzida por instâncias como a Unicef, a OIT, etc.), processos econômicos (por exemplo, a criação de um mercado global de produtos para a infância), processos culturais (por exemplo, a influência dos mitos infantis criados a partir das séries internacionais de televisão) e processos sociais (por exemplo, a institucionalização dos quotidianos da criança ou a difusão mundial da escola de massas).

Para Giddens (1991, p.64), a globalização é entendida como a "intensificação das relações sociais mundiais que unem localidades distantes de tal modo que os acontecimentos locais são condicionados por eventos que acontecem a muitas milhas de distância e vice-versa". Santos (1997, p.90) a considera como o "conjunto de relações sociais e culturais transacionais”. Libâneo (2005, p.70), ao abordar o tema, conceitua a globalização como "uma gama de fatores econômicos, sociais, políticos e culturais que expressam o espírito e a etapa do desenvolvimento do capitalismo em que o mundo se encontra atualmente".

Sarmento (2001, p.16-8), ao analisar os impactos da globalização na infância, trabalhou com as ideias de "globalização hegemônica e globalização contra-hegemônica".7 Como efeitos da globalização hegemônica, podemos constatar o estado de vulnerabilidade, miséria e exploração a que é submetida grande parcela das crianças do mundo, em especial dos países periféricos. Como exemplos: a crescente inserção da mão de obra infantil no mercado de trabalho; o aumento dos indicadores da pobreza infantil e o fortalecimento de um mercado global da infância influenciando na

7. Para aprofundar a discussão dos conceitos de globalização hegemônica e contra-hegemônica, consultar Santos (1997). 
formação dos padrões de comportamento, nos estilos de vida e nas culturas da infância. Em contrapartida, a globalização contra-hegemônica propaga um maior interesse pela criança, favorecendo a difusão mundial dos direitos da infância e a expansão de movimentos sociais em defesa da cidadania da infância, o que será analisado no próximo capítulo.

Retomando a ideia de que as concepções sobre a infância são forjadas no percurso da história, nos deparamos com o questionamento de alguns teóricos acerca do desaparecimento da infância na pós-modernidade. ${ }^{8}$ Porém, os estudos recentes da Sociologia da Infância demonstram que a infância é um projeto inacabado da modernidade e que seu curso tem revelado grandes paradoxos na contemporaneidade. A este respeito Sarmento (2004, p.19) esclarece:

Não obstante - contrariamente aos propagadores da "morte da infância" (Postman, 1999) - consideramos que a segunda modernidade radicalizou as condições em que vive a infância moderna, mas não a dissolveu na cultura e no mundo dos adultos, nem tão pouco lhe retirou a identidade plural nem a autonomia de acção que nos permite falar de crianças como actores sociais. A infância está em processo de mudança, mas mantém-se como categoria social, com características próprias.

Segundo Dahlberg, Moss \& Pence (2003, p.37), a Sociologia da Infância tem contribuído para a quebra de paradigmas sobre a infância, reconhecendo-a "como um importante estágio do curso de vida, nem mais nem menos importante do que outros estágios".

Esse entendimento da infância rompe com o paradigma da criança frágil, inocente, dependente e incapaz, dando lugar à concepção da criança rica, forte, poderosa e competente, coconstrutora de conhecimento, identidade e cultura. A criança é reconhecida como um sujeito ativo, competente, com potencialidades a serem

8. A este respeito consultar Corazza (2002, p.118-28). 
desenvolvidas desde o nascimento; sujeito que aprende e constrói conhecimentos no processo de interação social.

Essa construção da infância implica o reconhecimento de que:

- a infância é construção social elaborada para e pelas crianças em um conjunto ativamente negociado de relações sociais. Embora a infância seja um fato biológico, a maneira como ela é entendida é determinada socialmente;

- a infância como construção social é sempre contextualizada em relação ao tempo, ao local e à cultura, variando segundo a classe, o gênero e outras condições socioeconômicas. Por isso, não há uma infância natural nem universal, nem uma criança natural ou universal, mas muitas infâncias e crianças;

- as crianças são atores sociais, participando da construção e determinando suas próprias vidas, mas também a vida daqueles que as cercam e das sociedades em que vivem, contribuindo para a aprendizagem como agentes que constroem sobre o conhecimento experimental. Em resumo, elas têm atividade e função; os relacionamentos sociais e as culturas das crianças são dignos de estudo por direito;

- as crianças têm voz própria e devem ser ouvidas de modo a serem consideradas com seriedade, envolvendo-as no diálogo e na tomada de decisões democráticas, e para se entender a infância: as crianças contribuem para os recursos e para a produção sociais, não sendo simplesmente um custo e uma carga;

- os relacionamentos entre os adultos e as crianças envolvem o exercício de poder (assim como a expressão do amor). É necessário considerar a maneira como o poder do adulto é mantido e usado, assim como a elasticidade e a resistência das crianças a esse poder. (Dahlberg, Moss \& Pence, 2003, p.71)

Dessa forma, na construção de uma nova conceitualização sobre a infância está a ideia da criança cidadã, ou seja, a criança forte, competente, inteligente, com direito a voz e a ser ouvida; enfim, um sujeito de direitos: 
Desse entendimento de criança como coconstrutora, cidadã, agente, membro de um grupo, advém uma outra série de imagens. A criança como forte, competente, inteligente, um pedagogo poderoso, capaz de produzir teorias interessantes e desafiadoras, compreensões, perguntas - e desde o nascimento, não em uma idade avançada quando já ficaram prontos. Uma criança com uma voz para ser ouvida, mas compreendendo que ouvir é um processo interpretativo e que as crianças podem se fazer ouvir de muitas formas (conhecimentos expressos em As cem linguagens da infância, de Magaluzzi). Em resumo, essa construção da criança produz uma criança "rica". (Moss, 2001, p.242)

\section{Representações da infância: entre a natureza e a cultura}

Os estudos de Gagnebin (1997, p.84), focando a relação intrínseca entre infância e pensamento filosófico, apresentam o paradoxo entre a razão e a natureza que influenciará os sentimentos e concepções sobre a infância no pensamento medieval e início da Idade Moderna e que ainda se manifestam nas representações que fazemos sobre a infância.

No pensamento medieval, as ideias e concepções sobre a infância originadas em Platão e seguidas por santo Agostinho irão conceber a infância como um estado primitivo e animalesco do ser humano. A criança é considerada dotada de tendências selvagens, com disponibilidade para o mal em virtude da ausência da razão. Essa ideia pode ser compreendida no resgate etimológico da palavra infância, que significa o infante, aquele que não fala e que é privado da razão.

Assim, a infância caracteriza-se não pelo critério etário, mas pela ausência da linguagem humana, devendo a criança ser domesticada e moldada segundo as normas e regras educacionais.

Segundo Charlot (1986, p.113), o discurso de Platão apresenta uma visão de infância como um período em que a alma é dominada 
pela natureza corporal, remetendo à ideia da criança selvagem, indomável, que precisa ser educada e domesticada.

Em Platão, por exemplo, a infância é um momento do vir-a-ser individual da alma e as contradições do comportamento infantil explicam-se pelas características da alma. A alma da criança é prisioneira do sensível e dominada por sua natureza corporal: por isso a criança é selvagem e ardente como um potro, desordenada e agitada como um louco.

O discurso pedagógico tradicional encontra no discurso de Platão um respaldo para as práticas disciplinadoras e normativas. A infância é imaginada, antes de tudo, como a idade da corrupção, cabendo à educação a tarefa de desenraizar o estado selvagem natural da infância: "educação tem, portanto, essencialmente, por papel, lutar contra essa corrupção da criança, pode fazê-lo, uma vez que a criança por natureza, obedece ao adulto e uma vez que, na criança a humanidade já se anuncia” (Charlot, 1986, p.115).

Como marco do pensamento moderno sobre a infância, leva-se em consideração o livro de Jean-Jacques Rousseau, Emílio, datado de 1762. De acordo com Charlot (1986, p.116), Rousseau, contrapondo-se à visão da criança como adulto em miniatura, preconiza a ideia da existência de um mundo próprio e autônomo das crianças, reconhecendo a infância como tempo da pureza e da inocência, momento em que a natureza humana ainda não foi corrompida pela sociedade. Seus pressupostos irão influenciar decisivamente a pedagogia nova, ${ }^{9}$ considerando que a educação deverá atender ao ritmo e interesse de cada um, promovendo o desenvolvimento das faculdades naturais das crianças.

Charlot (1986, p.115) afirma que Rousseau irá revolucionar a pedagogia, inaugurando a pedagogia nova e promovendo uma

9. Segundo Charlot, a pedagogia nova propagava um discurso a favor da proteção e do respeito à natureza da criança, considerada como um "vir a ser", compreendendo a infância como um período de maturação. 
reinterpretação da natureza infantil e das relações entre adultos e crianças, o que favorecerá o surgimento da Psicologia da Criança.

Para Rousseau (apud Gagnebin, 1997, p.94), a ausência da linguagem racional, ao contrário de reiterar a natureza animal da criança, expressa uma autêntica linguagem dos sentimentos não corrompida pela linguagem mundana.

Essa infância idealizada é depositária de esperanças para um mundo melhor, expressando uma visão salvífica da criança.

Pode-se perceber nas concepções de Rousseau uma naturalização da infância, desconsiderando o seu significado social e a sua relação com o contexto histórico na qual ela se insere. Assim sendo, é preciso desnaturalizar a infância para rompermos com alguns paradigmas construídos historicamente.

Sarmento também reafirma a necessidade de desconstrução das imagens historicamente formuladas sobre a infância, visto que muitas ainda sustentam a atuação dos adultos com as crianças:

As diversas imagens sociais da infância frequentemente se sobrepõem e confundem no mesmo plano de interpretação prática dos mundos das crianças e na prescrição de comportamentos e de normas de actuação. Não são compartimentos simbólicos estanques mas dispositivos de interpretação que se revelam, finalmente no plano da justificação da acção dos adultos com as crianças. A busca de um conhecimento que se desagarre das imagens constituídas e historicamente sedimentadas não pode deixar de ser operada senão a partir de um trabalho de desconstrução dos seus fundamentos, essa perscrutação de sombra que um conhecimento empenhado no resgate da infância é chamado a fazer. (Sarmento, 2007, p.33)

No intuito de compreendermos as imagens da infância das profissionais que atuam nas creches de Franca buscamos a fundamentação metodológica na teoria das representações sociais. A opção pelo aporte teórico das representações sociais justifica-se pela necessidade de compreendermos as ideias, imagens, crenças e valores 
sobre o conceito de criança das profissionais que atuam com essa categoria no universo das creches de Franca.

Segundo Minayo (2004, p.158), "as representações sociais nas ciências sociais são definidas como categorias de pensamento que expressam a realidade, explicam-na, justificando-a ou questionando-a".

A compreensão das representações sociais dos sujeitos da pesquisa contribui para o entendimento do lugar que as crianças assumem nos espaços institucionais das creches.

Para o levantamento das representações sociais das narrativas dos discursos sobre a infância apresentadas pelas profissionais, recorremos aos dados qualitativos e quantitativos coletados por meio de questionários e entrevistas semiestruturadas. No primeiro instrumento metodológico, solicitamos que as entrevistadas escrevessem palavras para representar o conceito de criança.

As palavras afeto, ternura e amor apresentaram a maior frequência na ordem das evocações das palavras escritas para o conceito de criança, ou seja, foram elencadas por 21 das educadoras entrevistadas, totalizando $39,6 \%$ das respostas.

O agrupamento das evocações ocorreu pela busca dos significados das mesmas. Assim, no dicionário Novo Aurélio, encontramos o significado para o primeiro grupo de evocações. Para a palavra afeto encontramos: afeição, amizade, amor, objeto de afeição. A palavra ternura recebe os atributos de qualidade de terno, meigo, afetuoso, brando, suave, que inspira dó. E a palavra amor é compreendida como sentimento que predispõe alguém a desejar o bem de outrem, a dedicar-se ao outro, inclinação sexual forte por outra pessoa, afeição, amizade e simpatia (Ferreira, 1999).

Pode-se perceber que as educadoras entrevistadas reportam-se a uma visão da criança "frágil", reconhecida como um indivíduo a ser protegido, objeto de afeição e amor. Aliados a esse quadro, foram apresentadas as palavras encantadora, inocente, ingênua e pureza por 19 das entrevistadas, totalizando $35,8 \%$ das respostas.

Segundo o mesmo dicionário, a palavra encantadora pode ser compreendida como: encantar, lançar encantamento ou magia 
sobre, cativar, seduzir, deliciar, deleitar, tomar-se de encantos, maravilhar-se, transformar-se supostamente em outro ser por artes mágicas. A palavra inocente refere-se a inofensivo, inócuo, isento de culpa ou malícia, cândido, puro, pessoa inocente, criança de tenra idade. Significados semelhantes são encontrados para a palavra ingênua, ou seja, sem malícia, franco, inocente, puro, singelo ou filho de escrava nascido após a lei da emancipação. E para a palavra pureza encontramos os seguintes significados: estado ou qualidade de puro, limpo, inocente e cândido (Ferreira, 1999).

Sarmento (2007, p.30-2), ao apresentar as imagens da criança pré-sociológica, ${ }^{10}$ destaca a concepção de criança inocente. Segundo o autor, essa representação da infância tem como paradigma filosófico Emílio, a obra clássica de Rousseau, e apresenta como tese dominante que "a natureza é genuinamente boa e só a sociedade a perverte, o que se contrapõe à concepção oposta da necessidade da razão e da norma social para controlar as forças monstruosas da natureza indomada" (Sarmento, 2007, p.31).

Tanto o primeiro quadro de evocações quanto o segundo representam uma visão romântica da criança, herança do pensamento de Rousseau, fundamentada no mito da bondade da infância. A crença na bondade infantil traz implícita a ideia da criança como um "vir a ser”, ou seja, uma criança futuro do mundo, o que Moss (2002, p.239) afirma ser a "criança vista como um potencial não realizado, recurso futuro, adulto em espera”.

Essa visão romântica está também atrelada à concepção de natureza infantil, descrita por Charlot (1986, p.114), na qual se apoiam os sistemas pedagógicos. Fleury (1995, p.136) destaca que a concepção de natureza infantil colabora para o desenvolvimento

10. Segundo Sarmento (2007, p.30-2), as imagens das crianças pré-sociológicas são propostas pelos teóricos James, Jenks e Prout e revelam a concepção de criança como sujeito infantil abstrato e singular. As imagens propostas como imagens da criança pré-sociológica são as seguintes: "a criança má, a criança inocente, a criança imanente, a criança naturalmente desenvolvida e a criança inconsciente". 
de duas atitudes contraditórias dos adultos diante das crianças, ou seja, a paparicação e a moralização.

As contradições imputadas à natureza infantil são, portanto, múltiplas e a imagem que se faz da criança hoje em dia leva a duas atitudes contraditórias que caracterizam o comportamento dos adultos: uma é a da "paparicação" achando a criança ingênua, graciosa, pura, inocente; a outra considera a criança como um ser imperfeito, um ser que na verdade é um vir-a-ser, alguém incompleto que precisa de moralização e da educação dada pelo adulto.

A visão romântica e a imagem da criança inocente, frágil e dependente do adulto são reiteradas nas falas das entrevistadas: ${ }^{11}$

Um ser muito especial! Ser único, insubstituível, que merece cuidado, atenção, tudo de melhor que a gente puder fazer pra ela. [...] são seres inofensivos, são seres assim que precisam de muitos cuidados, de muita educação, então a gente tem que assegurar sim. (Dália)

Ah, eu acho que é assim... são pessoas muito especiais, alegres, precisam de muita atenção, cuidados. (Rosa)

A criança é muito pura e ingênua. (Angélica)

Para Dahlberg, Moss \& Pence, a imagem da criança inocente representa uma visão utópica, dando à infância o estatuto de "anos dourados" e refletindo nos adultos o desejo de proteção da criança do mundo que a cerca, o que poderá levar a um desrespeito dos direitos da criança:

11. Como já evidenciamos no percurso metodológico, foram entrevistadas cinco educadoras que atuam com a faixa etária de 0 a 3 anos de idade nas creches de Franca. 
Esta imagem da criança gera nos adultos um desejo de protegê-la do mundo corrupto que as cerca - violento, opressivo, comercializado e explorador - construindo um tipo de ambiente em que a criança pequena receba proteção, coesão e segurança. De acordo com nossa experiência, no entanto, nós nos tornamos cada vez mais cientes de que, se escondermos as crianças de um mundo do qual elas fazem parte, não apenas nos iludimos, mas não levamos as crianças a sério nem as respeitamos. (Dahlberg, Moss \& Pence, 2003, p.66)

Como afirmam Moreira \& Vasconcelos (2003), muitas das representações sobre a infância convergem para uma concepção homogênea, independente do contexto social, uma infância idealizada, perfeita e encantada que remete à teoria rousseauniana do "Bom Selvagem”. Para as autoras, essas representações expressam um modelo "idílico de infância", uma visão utópica, compreendida como uma fase mágica e bela, "vivida por uma criança meiga, inocente, preservada da mágoa e do trabalho, ocupando seu tempo apenas no devaneio do brincar, tratada com carinho e proteção por uma família" (Moreira \& Vasconcelos, 2003, p.167).

As representações sobre a infância que evocam o modelo idílico não expressam a realidade de todas as crianças, em especial das camadas populares inseridas precocemente no trabalho, excluídas da escola, vivendo em situação de miséria, abandono e exploração, enfim, para as quais o "paraíso da infância" é uma grande utopia. Confrontamo-nos assim com diferentes formas de vivência da infância quando consideramos as diferentes demarcações de suas condições socioeconômicas e culturais.

A visão adultocêntrica também é uma constante nas representações das educadoras entrevistadas, revelando, sobretudo, uma concepção de educação meramente transmissiva e a visão de uma criança reconhecida como sujeito passivo e depositária de conhecimentos: 
[...] desde lá no berçário ela percebe o que você quer passar para ela. A gente pensa que ela não vai entender, como exemplo, quando eu falo neném, ela entende. Então por isso é bom a gente saber o conhecimento que pode estar passando pra ela e planejar também o que a gente pode estar ensinando pra ela. (Angélica)

Conforme a concepção de criança apresentada por Angélica, temos a presença do que Sarmento (2007, p.31) considerou como visão da criança imanente, ou seja, visão na qual se apresenta um potencial de desenvolvimento da criança relacionado à possibilidade de aquisição da razão e da experiência.

Constata-se que a criança está representada enquanto ser dependente do adulto, isto é, por sua condição de fragilidade ou de incapacidade.

A discussão da concepção de criança como incapaz, um vir a ser, é discutida por Sarmento (2007, p.33) quando o autor apresenta os traços de negatividade sobre a infância na modernidade. A visão sobre a criança parte de sua incompletude, do que lhe falta para se tornar um adulto. Na modernidade, a infância consagra-se como a idade da não razão, do não trabalho e da não infância, esta última defendida pelos teóricos que partilham da ideia do desaparecimento da infância.

A negatividade na concepção da infância é apresentada na fala das entrevistadas ao apontarem as limitações das crianças e o papel do adulto na estimulação das mesmas:

[...] porque toda a criança tem as suas limitações, mas ela também tem sua capacidade de superar, então a gente dá valor a tudo que ela pode contribuir, estimulando sempre. [...] porque às vezes tem alguma criança que tem alguma limitação, mas a gente estimulando, trabalhando com ela, ela é capaz de desenvolver bem como outra qualquer. (Dália)

[...] a gente está ali com ela, vendo o que ela precisa, vendo como é. [...] como elas ainda não têm..., como elas são novas ainda se você falar um dia pra elas não vão lembrar, então são 
coisas que você fala diariamente pra elas poder gravar, pra elas poderem gravar sobre aquele assunto. [...] mas ela não consegue sozinha, então se você estimular então ela começa a desenvolver sozinha, mas precisa de uma estimulação no começo. (Angélica)

[...] eu descobri que posso ajudar crianças a superarem certas dificuldades que atrapalham na aprendizagem. (Rosa)

Contrapondo a representação majoritária da visão romântica de criança, os dados dos questionários apresentaram, em menor frequência, evocações que revelam a visão da criança como sujeito social, histórico, competente e produtor de cultura. As palavras social e histórica foram citadas por três das entrevistadas, representando $5,6 \%$ das evocações, ao passo que competente e produtor de cultura foram citadas apenas por uma educadora, representando o percentual de 1,8\% no quadro das evocações.

A visão de criança como sujeito ativo que constrói conhecimentos é revelada na representação do conceito de criança de Íris e Gardênia:

A criança..., criativa, esperta, muito curiosa, o tempo todo em busca de conhecimentos. [...] o tempo todo querendo novidade, então você vê que são crianças que buscam o novo, que têm vontade de aprender. (Gardênia)

[...] sem eles a gente não teria a creche, eu não estaria aqui. Eles são os autores principais dentro desta história. [...] a rotina que se faz é pra eles, as atividades que se pensa em se fazer está em torno deles, então eles são os autores principais. (Íris)

Como podemos constatar, as representações das imagens de criança da maioria das profissionais das creches de Franca é contrária ao discurso legal e pedagógico, que propaga uma visão de criança como sujeito social de direitos e produtor de cultura, como é revelado pela Política Nacional de Educação Infantil: 
[...] contudo, as formas de ver as crianças vêm, aos poucos, se modificando, e atualmente emerge uma nova concepção de criança como criadora, capaz de estabelecer múltiplas relações, sujeito de direitos, um ser sócio-histórico, produtor de cultura e nela inserido. (Brasil, 2006, p.8)

Percorrendo a construção histórica do conceito de criança apresentado pelos discursos teóricos, bem como as representações sociais das educadoras entrevistadas, constatamos que ambas revelam uma compreensão complexa e contraditória do que seja a criança e o seu papel na sociedade. À predominância da visão focada na natureza infantil em nossa pesquisa alia-se a ideia da criança abstrata, independente de sua condição social e cultural, uma criança frágil e dependente do adulto, a ser conduzida e normatizada pelo processo educacional. Permite-nos perceber a importância da desconstrução das representações sociais sobre as crianças para que elas verdadeiramente possam assumir a condição de sujeitos de direitos nos espaços das creches. 



\section{3 \\ DIREITOS DA INFÂNCIA: DA TUTELA E PROTEÇÃO À CIDADANIA E EDUCAÇÃO}

As leis acendem uma luz importante, mas elas não são todas as luzes.

O importante é que um ponto luminoso ajuda a seguir o caminho.

Cury, 2002

\section{Os documentos internacionais e os dispositivos legais}

O reconhecimento dos direitos da infância e da condição da criança como sujeito de direitos é fato recente na história brasileira e em outros países do mundo.

A história dos direitos da infância, assim como a história da criança, é uma construção social configurada pelo caráter paradoxal quanto ao reconhecimento da necessidade do direito e aos entraves para sua efetivação.

Os investimentos científicos sobre a infância a partir do século XIX, em especial da Psicologia e Pedagogia, contribuíram 
para a construção de imagens da criança como um "vir a ser" e para a construção de práticas normativas quanto ao seu desenvolvimento e atendimento. No campo dos direitos contribuíram para a imagem da criança vulnerável e necessitada de proteção (Soares, 1997, p.78).

No século XX, o discurso predominante sobre a infância atribuiu-lhe o estatuto de sujeito de direitos, imagem construída com base na elaboração de dispositivos legais e documentos internacionais, entre os quais: a Declaração de Genebra (1923), a Declaração Universal dos Direitos da Criança (1959) e a Convenção dos Direitos da Criança (1989).

Bobbio (1992, p.18), ao analisar a evolução dos direitos, aponta a influência das condições históricas na formulação dos direitos do homem. Dessa forma, os direitos proclamados nas declarações apresentam uma dimensão histórica pautada nas exigências de cada contexto histórico.

A esse respeito, Fullgraf (2001, p.29) também esclarece:

Os direitos do homem, por mais fundamentais que possam ser, são direitos históricos, que nascem em certas circunstâncias, e que na verdade se caracterizam por lutas em defesa de novas liberdades contra velhos poderes. A luta por novos direitos surge de modo gradual e não todos ao mesmo tempo. O conjunto de direitos do homem modificam-se e continuam a se modificar com a mudança das condições históricas. Assim pode-se afirmar que não existem direitos fundamentais, ou seja, o que parece fundamental num certo contexto histórico e numa determinada civilização não é fundamental em outros momentos ou em outras culturas.

Considerando os conceitos de infância e criança enquanto construções históricas, pode-se afirmar a historicidade da luta dos direitos para essas categorias sociais.

Segundo Natália Fernandes Soares, pesquisadora do Instituto de Estudos da Criança da Universidade do Minho, Portugal, até o 
século XVI não havia o reconhecimento dos direitos e das necessidades das crianças, pois estas eram subjugadas pelo poder sem limites dos pais, estando em condições de ser ignoradas, abandonadas, abusadas, vendidas ou até mesmo mutiladas. A condição da criança na sociedade e sua separação do mundo, gradualmente, serão modificadas a partir do século XVI:

É a partir do século XVI que se iniciam as mudanças mais significativas, que viriam a alterar a posição e estatuto das crianças relativamente aos adultos. Atitudes associadas à sobrevivência, proteção e educação das crianças, que, gradualmente se foram fortalecendo durante os séculos XVII e XVIII, começaram a permitir delinear um espaço social especial destinado às crianças, no qual é já possível salvaguardar algumas das suas necessidades e direitos. (Soares, 1997, p.78)

Segundo Marcílio (1998, p.47), a origem e o desenvolvimento do processo de criação dos Direitos da Criança inicia-se nos séculos XVII e XVIII com a formulação dos Direitos Naturais do Homem e do Cidadão, sucedida pela Declaração Universal dos Direitos Humanos em $1948 .^{1}$

No século XIX, a criança será reconhecida como uma categoria social com necessidades de proteção, em especial pelas contribuições das ciências da Pedagogia, Psicologia e Medicina. Porém, será no século XX que novos significados serão atribuídos à infância, "através de uma nova conscientização de que as crianças eram fontes humanas essenciais, de cuja dimensão maturacional iria depender o futuro da sociedade" (Soares, 1997, p.78).

Os trabalhos pioneiros em defesa do reconhecimento dos direitos da infância, segundo Soares (1997, p.78), encontram-se nas lutas da inglesa Eglantine Jebb (1914), responsável pela fundação

1. A Declaração Universal dos Direitos Humanos, criada no contexto histórico do pós-guerra, visava atingir a todos os homens promovendo um conjunto de direitos e responsabilidades necessárias à participação plena dos indivíduos na sociedade. 
de um movimento internacional de discussão das repercussões das guerras na vida das crianças, o Save the Children Fund International Union, o qual se tornou base para que, em 1923, fosse promulgada a Primeira Declaração dos Direitos da Criança, conhecida como Declaração de Genebra. Conforme Soares (1997, p.80), o texto da Declaração ressalta um discurso da proteção e auxílio à infância enfocando o atendimento às necessidades de sobrevivência das crianças.

No ano de 1946, como resultado da necessidade de assistência às crianças órfãs da Segunda Guerra Mundial, a Organização das Nações Unidas (ONU) criou o United Nations Internacional Child Emergency Fund (Unicef) visando à criação de um fundo internacional de ajuda à infância necessitada, cuja atenção inicial foi destinada às crianças da Europa, China e refugiados da Palestina.

Em 1953, o Unicef tornou-se um órgão permanente da ONU e, em 1958, seus investimentos passaram a incorporar os serviços sociais para a criança e suas famílias, abrangendo também os serviços de educação.

A condição da criança, como prioridade absoluta e sujeito de direitos, é proclamada com a Declaração Universal dos Direitos da Criança em 1959, que no sétimo de seus princípios estabelece:

A criança tem direito a receber educação escolar, a qual será gratuita e obrigatória, ao menos nas etapas elementares. Dar-se-á à criança uma educação que favoreça sua cultura geral e lhe permita - em condições de igualdade de oportunidades - desenvolver suas aptidões e sua individualidade, seu senso de responsabilidade social e moral. Chegando a ser um membro útil à sociedade.

$[\ldots]$

A criança deve desfrutar plenamente de jogos e brincadeiras, os quais deverão estar dirigidos para educação; a sociedade e as autoridades públicas se esforçarão para promover o exercício deste direito. $[\ldots]$ 
Os demais princípios inovam em relação às declarações anteriores reconhecendo à criança o direito à nacionalidade, ao nome e a desenvolver-se em um clima de paz e amizade.

No início da década de 1970, ${ }^{2}$ intensificaram-se as discussões para que os direitos das crianças, até então proclamados, tivessem respaldo na lei internacional, obrigando os Estados a constituírem um elenco de obrigações mais específicas de proteção da infância, o que contribuiria para a formulação da Convenção das Nações Unidas sobre os Direitos da Criança.

A Convenção das Nações Unidas sobre os Direitos da Criança, proclamada em 1989, constituiu-se em um tratado inovador, internacional e dotado de caráter universal, visto ser ratificado por 192 países. ${ }^{3}$

Conforme Fullgraf (2001, p.33):

A Convenção teve por objetivo reunir em um único documento as diferentes medidas internacionais de proteção à criança representando um forte instrumento inovador, internacionalmente reconhecido dos direitos das crianças, sendo assim um marco fundamental no percurso da construção e definição de um estatuto digno para todas as crianças.

A Convenção sobre os Direitos da Criança em seus 54 artigos enuncia um amplo conjunto de direitos fundamentais (civis e políticos) e direitos econômicos, sociais e culturais:

A Convenção define como criança qualquer pessoa com menos de 18 anos de idade (artigo 1ํ), cujos "melhores interesses" devem ser considerados em todas as situações (artigo 3). Protege os direitos da criança à sobrevivência e ao pleno desenvolvimento (ar-

2. O ano de 1979 foi declarado pela ONU como o Ano Internacional da Criança, contribuindo para a avaliação dos caminhos percorridos pelos direitos da infância.

3. No Brasil, a Convenção dos Direitos da Criança foi ratificada em 20 de setembro de 1990. 
tigo $6^{\circ}$ ), e suas determinações envolvem o direito da criança ao melhor padrão de saúde possível (artigo 24), de expressar seu ponto de vista (artigo 12), e de receber informações (artigo 13). A criança tem o direito de ser registrada imediatamente após o nascimento, e de ter um nome e uma nacionalidade (artigo 7으), tem o direito de brincar (artigo 31), e de receber proteção contra todas as formas de exploração sexual e de abuso sexual (artigo 34). (Marcílio, 1998, p.49)

Soares (1997, p.81) reitera o caráter inovador da Convenção que, ao estabelecer normas internacionais no trato dos direitos da infância, especifica a responsabilidade de cada Estado no estabelecimento de legislações que validem os princípios da Convenção.

O conjunto de direitos dispostos no texto da Convenção pode ser agrupado em três categorias:

- Direitos relativos à provisão - onde são reconhecidos os direitos sociais da criança, relativamente à salvaguarda da saúde, educação, segurança social, cuidados físicos, vida familiar, recreio e cultura;

- Direitos relativos à protecção - onde são identificados os direitos da criança a ser protegida contra a discriminação, abuso físico e sexual, exploração, injustiça e conflito;

- Direitos relativos à participação - onde são identificados os direitos civis e políticos, ou seja, aqueles que abarcam o direito da criança ao nome e identidade, o direito à liberdade de expressão e opinião e o direito a tomar decisões em seu proveito. (Hammaerberg, 1999 apud Soares, 1997, p.82, grifo do autor)

Soares e Tomás consideram que os documentos internacionais e os esforços legislativos contribuíram para uma imagem da criança como sujeito de direitos e a propagação de um discurso de proteção à infância.

No século XXI, emerge a construção da imagem da criança cidadã, o que requer, além da efetivação dos direitos de provisão e proteção, os direitos relativos à participação, "o que implica, para 
além de outros aspectos, à valorização e à aceitação da sua voz e a sua participação nos seus quotidianos, ou seja, nos diversos 'mundos' que a rodeiam e onde está inserida" (Soares \& Tomás, 2004, p.143).

É importante destacarmos que a efetivação dos direitos relativos à participação é fundamental no cenário das instituições de educação para que as crianças possam exercer a condição de sujeitos ativos nesses espaços institucionais.

O Brasil, assim como vários países do mundo, tornou-se signatário dos preceitos da Convenção, o que exigiu do Estado a elaboração de dispositivos legais coadunados ao código normativo da Convenção, bem como a implementação de políticas públicas em defesa dos direitos da infância.

Segundo Marcílio (1998, p.50), o Brasil antecede os preceitos da Convenção reconhecendo a criança como sujeito de direitos na Constituição de 1988, conforme o que dispõe o artigo 227 da Carta Magna:

É dever da família, da sociedade e do Estado assegurar à criança e aos adolescentes com absoluta prioridade, o direito à vida, à saúde, à alimentação, à educação, ao lazer, à profissionalização, à cultura, à dignidade, ao respeito, à liberdade e à convivência familiar e comunitária, além de colocá-la a salvo de toda forma de negligência, discriminação, exploração, violência, crueldade e opressão.

Os dispositivos da Constituição Federal foram antecedidos pelas legislações internacionais e pelos trabalhos da Frente Parlamentar pela Constituinte. No ano de 1987 realizaram-se também os trabalhos da Comissão Nacional da Criança e Constituinte, instituída por portaria interministerial e por representantes da sociedade civil organizada.

Apesar dos avanços legais em relação aos direitos da criança, o panorama global sobre a infância demonstra que essa categoria ainda não é prioridade na agenda governamental de muitos países, 
resultando na ausência de investimentos do Estado em políticas e dispositivos legais para a efetivação dos direitos das crianças.

A esse respeito, Tomás (2006, p.42) analisa os impactos da globalização nos direitos da infância, ressaltando o "hiato" existente entre os termos internacionais e a realidade local de milhões de crianças.

Diante dos efeitos da globalização, Sarmento (2001, p.25) afirma que o movimento de construção dos direitos da infância "é uma das faces mais impressivas da globalização contra-hegemônica”. Segundo o autor, a globalização produz efeitos contraditórios e complexos na identidade contemporânea da infância, agindo sobre dois polos. No primeiro polo, registra-se a tendência reguladora dos organismos internacionais, dentre eles a ONU, Unicef, Organização das Nações Unidas para a Educação, Ciência e Cultura (Unesco) e Organização Internacional do Trabalho (OIT) visando ao que seja "o melhor interesse da criança", e no segundo, revelam-se os índices alarmantes quanto ao agravamento da situação mundial da infância. Como afirmou a diretora executiva do Unicef em 2004, na reunião dos líderes dos países mais ricos, sobre dados da terrível situação em que se encontram as crianças dos países pacíficos: "12.500 crianças morrem de malária, uma criança fica órfã a cada 14 segundos devido à SIDA/AIDS, é negada escolarização a 65 milhões de meninas, 160 milhões encontram-se em situação de má nutrição e 22.000 crianças morrem de diarreia" (Tomás, 2006, p.45).

A evolução histórica do atendimento, promoção e defesa dos direitos da criança e do adolescente no Brasil é analisada por Costa (1994, p.122-45). Segundo o autor, as ações relativas à infância, do descobrimento aos anos 1960, são marcados por um caráter assistencialista, normativo, correcional e repressivo, a exemplo da Política Nacional de Bem-Estar do Menor e do Código de Menores. As décadas de 1970 e 1980 são consideradas cenários para o surgimento das recentes lutas travadas no país em favor das crianças e dos adolescentes. Seus estudos apontam a importância de se aliar a história dos direitos da infância à história das políticas sociais. Afirma, ainda, que os movimentos populares da década de 1980, 
em especial o Movimento de Meninos de Rua, contribuíram para a discussão da situação da infância brasileira, provocando a elaboração e implantação de um novo ordenamento jurídico sobre a infância e a adolescência no país.

\section{Os direitos da infância no Brasil}

Como vimos, a construção dos direitos das crianças percorre uma história configurada por lutas, avanços, embates e desafios para que os princípios estabelecidos nos dispositivos legais internacionais sejam incorporados ao quadro legal específico das nações. Cury (1998, p.9) recorre a Bobbio (1992) para a explicação desse processo:

Bobbio (1992), quando reflete sobre os direitos no mundo contemporâneo, diz que a evolução dos direitos - sobretudo dos direitos sociais, para se converterem em Direito Positivo, portanto inscritos no âmbito das Constituições ou das Leis em geral dá-se por meio de um processo. Em primeiro lugar ocorrem experiências, pressões, num jogo mais segmentado. Disto resulta algo generalizado, ou seja, há uma generalização daquela discussão, daquela pressão. Depois criam-se novas expectativas que acabam por atingir vários países, várias nações. Ganham, assim, um caráter de internacionalização. No caso dos direitos das crianças, a Declaração da ONU a esse respeito é de 1959.

O processo de reconhecimento e legitimação dos direitos da infância é marcado pelo caráter paradoxal, em especial no cenário atual, em que as políticas de ajustes na economia dos países periféricos às regras do mercado mundial têm agravado as condições de vida das populações, em especial das crianças, reconhecidas como categoria mais vulnerável às mudanças societárias.

Apesar de todo o embate para conquista e efetivação dos direitos da infância, a década de 1980 foi um marco na trajetória da história dos direitos das crianças brasileiras. 
A movimentação internacional em defesa dos direitos da infância, aliada à luta dos movimentos sociais no país, contrapondo-se ao regime autoritário militar e pela conquista da democracia, culminou com a instauração de um novo campo legal para as políticas de atendimento à infância, em que a criança deixará de ser objeto de tutela para figurar como sujeito de direitos. Nesse novo campo normativo interessa-nos a discussão do reconhecimento do direito da criança à educação infantil.

Segundo Cury (1998, p.10), anteriormente à Constituição de 1988, a questão da infância no âmbito constitucional restringia-se ao "amparo e à assistência", contrapondo-se à questão do dever e do direito. As duas primeiras constituições brasileiras, a de 1824, outorgada no período imperial, e a de 1891, a primeira Constituição Republicana, nada mencionam a respeito da infância.

A Constituição de 1937 faz referência a que o Estado deveria providenciar cuidados especiais à infância, cabendo ao Estado Novo o "cuidado e o amparo", em vez do "dever e do direito"; e na Constituição de 1946, promulgada no clima de pós-guerra mundial, encontram-se os termos amparo e assistência. Ela defendia a educação como direito de todos e preceituou a descentralização no formato administrativo e pedagógico do sistema educacional brasileiro, culminando com a aprovação da primeira Lei de Diretrizes e Bases da Educação Nacional, a Lei n. 4.024/1961.

A Lei n. 4.024/1961 fez referência discreta à educação infantil, considerando-a no grau primário, como educação pré-escolar destinada às crianças menores de sete anos, podendo ser oferecida através das escolas maternais e jardins da infância. Previa também que as empresas organizassem diretamente ou em cooperação com o poder público a educação dos filhos de suas trabalhadoras com menos de sete anos (Cury, 1998, p.10-1).

Com a Constituição de 1967, aprovada no país após o golpe militar de 1964, e da Junta Militar de 1969, é que se introduz a noção de que uma lei própria regulamentaria a assistência à infância.

No ano de 1971, em uma conjuntura histórica marcada por um Estado autoritário a serviço da classe dominante, com preocupação excessiva dirigida ao crescimento econômico, é promulgada a se- 
gunda Lei de Diretrizes e Bases da Educação Brasileira, a Lei n. 5.692/1971. Dentre as alterações ao texto podemos destacar a fusão dos antigos ensinos primários e ginasial, organizados em um currículo único de oito anos (ensino de 1o grau) e a reestruturação do

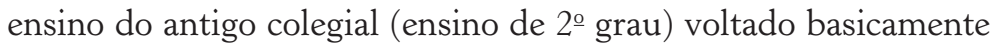
para uma feição profissionalizante. No campo da educação infantil, a Lei reforça a questão das empresas quanto à educação dos filhos de suas trabalhadoras, já anunciada na Lei n. 4.024/1961.

\section{O aparato legal da infância a partir dos anos 1980}

A atual Constituição Federal foi promulgada em 1988, após um período de ditadura militar e de grandes lutas pela democratização do país. No processo de sua elaboração houve intensa mobilização dos movimentos populares pela garantia de seus direitos básicos na nova Lei.

Em relação à participação dos movimentos populares no processo de discussão e elaboração da atual Constituição, Fullgraf (2001, p.36) destaca as contribuições da Associação Nacional de Pós-Graduação e Pesquisa em educação e dos grupos de defesa dos direitos humanos, principalmente do Conselho Nacional dos Direitos da Mulher, os quais contribuíram para que creches e pré-escolas fossem integradas ao texto constitucional no âmbito da educação.

A Constituição de 1988 apresentou e representou grandes avanços no que se refere aos direitos sociais e às possibilidades de concretização do Estado do Bem-Estar Social; ressaltou a necessidade de descentralizar a política administrativa com ênfase no papel do município e, principalmente, na garantia de participação da sociedade civil na implementação das políticas sociais.

Em relação às políticas de atenção à infância, inaugurou um novo momento na história da legislação infantil ao reconhecer a criança como cidadã. Segundo Angotti (2006, p.18): 
Com a promulgação da Carta Magna em 1988, emerge e se reconhece o estado de direito do cidadão criança, um novo estatuto social deve e terá que ser desenhado para o cotidiano, exigindo investimentos distintos e integrados na consolidação de uma nova ordem social.

A Carta Magna estabeleceu a responsabilidade do Estado pela educação infantil em creches e pré-escolas, conforme o artigo 280, inciso IV, e também o direito dos trabalhadores (homens e mulheres) em ter assegurada a assistência gratuita aos seus filhos e dependentes desde o nascimento até 5 anos em creches e pré-escolas, de acordo com o artigo 7o, inciso XXV, ${ }^{4}$ ampliando significativamente o proposto pela Consolidação das Leis do Trabalho (CLT) de 1943. Estabeleceu como competência da União prestar assistência técnica e financeira aos estados, ao Distrito Federal e aos municípios para garantir equalização das oportunidades e padrão mínimo de qualidade.

Conforme o artigo 211, $\S 2$, foi determinado que os municípios atuassem prioritariamente no ensino fundamental e na educação infantil, revelando o princípio da descentralização da educação por meio de uma política de desarticulação entre as esferas do governo e a indefinição de papéis no atendimento aos diferentes níveis de ensino.

Conforme os dispositivos constitucionais, o atendimento ao ensino superior compete à esfera federal; aos estados compete o atendimento ao ensino médio e fundamental, ao passo que aos municípios compete atender à educação infantil e ao ensino fundamental.

Fullgraf (2001, p.40) assinala que o princípio da descentralização está atrelado a uma visão reducionista do papel do Estado em

4. A Ementa Constitucional n. 53, de 19 de dezembro de 2006, dá nova redação ao artigo $7^{\circ}$ da Constituição Federal, estabelecendo no inciso XXV a assistência gratuita aos filhos e dependentes dos trabalhadores desde o nascimento até os 5 anos de idade. 
relação às políticas públicas, "comprometendo a consolidação do atendimento educacional de qualidade às crianças pequenas, como também a todos os outros níveis de ensino".

A história do atendimento à infância que antecede a Constituição de 1988 demonstrou o predomínio da ação da assistência social à infância desenvolvida por várias instituições, como os asilos infantis (século XIX), as creches, as escolas maternais e os jardins de infância.

Com o novo texto constitucional, as creches passaram a ser legitimadas como instituições educativas, direito das crianças e das famílias trabalhadoras de usufruírem de espaços coletivos para os cuidados e educação de seus filhos. Compreendida em tempos passados como "mal necessário", o benefício à mãe trabalhadora é reconhecido como instituição de educação infantil, não podendo mais se diferenciar das demais instituições de atendimento às crianças pequenas quanto aos seus objetivos e ações.

Conforme afirma Craidy (2002, p.58), a Constituição contribuiu para a afirmação de uma nova doutrina em relação à criança $e$ às instituições de educação infantil:

Impunha-se, assim, a partir da Carta Constitucional, a superação da tradição clientelista e paternalista que marca a história do Estado e da sociedade no Brasil. Foi também a Constituição que, pela primeira vez na nossa história afirmou a cidadania da criança ao estabelecer que ela é sujeito de direitos. Definiu, ainda, que a creche e a pré-escola são direitos não só da criança como de seus pais trabalhadores, homens e mulheres, e afirmou a natureza educativa da creche e pré-escola.

Didonet (2001, p.14), esboçando o papel das creches no conjunto da educação infantil, apresenta seus objetivos institucionais no âmbito social, educacional e político.

Em relação ao objetivo social, refere-se à necessidade de as creches darem suporte às mulheres no cumprimento de sua função materna, sem haver vinculação do atendimento à incapacidade das 
famílias nos cuidados e educação dos filhos ou mesmo despertando sentimentos de culpa. As creches têm assim uma expressiva contribuição para o movimento libertário das mulheres, possibilitando às mesmas compreender as armadilhas ideológicas que definiram o papel social da mulher como mantenedora do lar e cuidadora da prole.

A creche centrada na criança, como sujeito de educação, expressa em seu objetivo educacional a importância da infância para o desenvolvimento do ser humano, reconhecendo a amplitude do seu espaço educativo, aberto a todas as crianças, independentemente do trabalho materno extradomiciliar: "a creche organiza-se para apoiar o desenvolvimento, promover a aprendizagem, mediar o processo de construção e conhecimentos e habilidades, por parte da criança, procurando ajudá-la a ir o mais longe possível nesse processo" (Didonet, 2001, p.15).

O objetivo político vincula a questão da educação infantil na formação do cidadão, reconhecendo a criança como cidadã desde o nascimento.

Conforme o autor, no mundo moderno, a cidadania passa a ser atributo da dignidade e se fundamenta nos direitos da pessoa. Reafirma que do reconhecimento formal ao exercício de direitos há um espaço a ser conquistado, por isso se diz que a cidadania é conquistada e não concedida. Observa que essa conquista em relação à criança é ainda mais difícil pela existência de dupla dominação a ser vencida: a física e a psicológica:

[...] a física é consequência da fragilidade da criança, diante do adulto que gera a necessidade de proteção, a dependência, a possibilidade de ser por ele submetido e dominado. A psicológica, derivada da compreensão do adulto de que ele é o coroamento da evolução e, por isso, se coloca como parâmetro. (Didonet, 2001, p.15)

Em relação aos avanços e aos desafios da educação infantil anunciados pela Constituição Federal, Cury (1998, p.14) argu- 
menta que temos um longo caminho a percorrer para que as instituições de educação infantil tornem-se espaços de promoção e defesa da cidadania das crianças.

No âmbito legal, as lutas foram implementadas por novas legislações em defesa dos direitos das crianças e adolescentes no país, contribuindo para mudanças no quadro das políticas públicas para a infância, enfatizando as responsabilidades das famílias, da sociedade e do Estado.

Em 1990 foi elaborado e sancionado o Estatuto da Criança e do Adolescente, Lei n. 8.069/1990. Esse ordenamento legal substitui o caráter assistencialista corretivo e repressivo das ações sócioeducativas introduzindo uma concepção de proteção integral drecionada às crianças e aos adolescentes. Reconhece e reitera os dispositivos constitucionais em relação à condição de sujeitos de direitos das crianças e dos adolescentes, a sua condição peculiar de desenvolvimento e à necessidade de serem considerados prioridade absoluta na agenda das políticas públicas.

Segundo Costa (1994, p.140), o Estatuto da Criança e do Adolescente contribui para uma nova organização dessas políticas, que podem ser agrupadas em políticas sociais básicas, políticas assistenciais e programas de proteção especial para crianças e jovens em circunstâncias especialmente difíceis.

Os artigos 3ำ e 4o enfatizam a concepção de proteção integral e estabelecem as responsabilidades das famílias, da sociedade e do Estado na garantia dos direitos para a infância e a adolescência.

Art. $3^{\circ}$ - A criança e o adolescente gozam de todos os direitos fundamentais inerentes à pessoa humana, sem prejuízo da proteção integral de que trata esta Lei, assegurando-se-lhes, por lei ou por outros meios todas as oportunidades e facilidades, a fim de lhes facultar o desenvolvimento físico, mental, moral, espiritual e social, em condições de liberdade e de dignidade.

Art. 4o-É dever da família, da comunidade, da sociedade em geral e do Poder Público assegurar, com absoluta prioridade, a efetivação dos direitos referentes à vida, à saúde, à alimentação, 
à educação, ao esporte, ao lazer, à profissionalização, à cultura, à dignidade, ao respeito, à liberdade e à convivência familiar e comunitária.

No artigo 53, o ECA referencia a contribuição da educação ao desenvolvimento pleno da pessoa, à conquista da cidadania e à qualificação para o trabalho, destacando, ainda, aspectos fundamentais da educação como política pública quanto à necessidade de igualdade de condições para o acesso à escola pública.

$\mathrm{O}$ artigo 54 enfatiza a obrigatoriedade do Estado no atendimento às crianças de $0 \mathrm{a} 6$ anos em creches e pré-escolas e o artigo 11 estabelece a incumbência do município em oferecer a educação infantil, porém ressaltando a prioridade dele no ensino fundamental. O Estatuto estabelece, ainda, a criação de instrumentos na defesa do atendimento aos direitos das crianças e dos adolescentes, que são os Conselhos dos Direitos da Criança e do Adolescente.

A Lei Orgânica da Assistência Social (Loas), de 1993, vem complementar e reafirmar o papel do Estado na atenção à infância em seu artigo 20: "A assistência social tem por objetivos: I) proteção à família, à maternidade, à infância, à adolescência e à velhice; II) o amparo às crianças e adolescentes carentes". Em seu artigo 4o, enfatiza a universalização dos direitos sociais e a importância da integração das políticas de educação, saúde e assistência.

No ano de 1994, o Ministério da Educação e do Desporto, norteado pela Constituição Federal e pelo Estatuto da Criança e do Adolescente, formulou diretrizes para uma Política Nacional de Educação Infantil, ${ }^{5}$ publicando e divulgando uma série de documentos científicos acerca do compromisso das creches e pré-escolas com a defesa da cidadania das crianças de 0 a 6 anos.

5. A relevância histórica dessa política é expressada tanto pelo conteúdo apresentado quanto pela maneira com que foi elaborada, com a participação de dirigentes e técnicos de instituições federais, estaduais e municipais, professores universitários, especialistas e representantes de instituições internacionais e de entidades não governamentais. 
A formulação da política de educação infantil reconhece o direito das crianças pequenas à educação, valorizando o papel da infância no desenvolvimento do ser humano e, sobretudo, a importância da educação na construção da cidadania.

As diretrizes propostas pela Política Nacional de Educação Infantil baseiam-se nos seguintes princípios:

1) A educação é a primeira etapa da educação básica e destina-se à criança de zero a seis anos de idade, não sendo obrigatória, mas um direito que o Estado tem obrigação de atender;

2) As instituições que oferecem educação infantil, integrantes dos sistemas de ensino, são as creches e pré-escolas, dividindo-se a clientela entre elas pelo critério exclusivo da faixa etária (zero a três anos na creche e quatro a seis anos na pré-escola);

3) A educação infantil é oferecida para, em complementação à ação da família, proporcionar condições adequadas de desenvolvimento físico, emocional, cognitivo e social da criança e promover a ampliação de suas experiências e conhecimentos, estimulando seu interesse pelo processo de transformação da natureza e pela convivência em sociedade;

4) As ações de educação, na creche e na pré-escola, devem ser complementadas pelas de saúde e assistência, realizadas de forma articulada com os setores competentes;

5) O currículo de educação infantil deve levar em conta, na sua concepção e administração, o grau de desenvolvimento da criança, a diversidade social e cultural das populações infantis e os conhecimentos que se pretendam universalizar;

6) Os profissionais de educação infantil devem ser formados em curso de nível médio ou superior, que contemplem conteúdos específicos relativos a essa etapa da educação;

7) As crianças com necessidades especiais devem sempre que possível, ser atendidas na rede regular de creches e pré-escolas. (Brasil, 1994, p.15)

O referido documento estabelece as diretrizes pedagógicas para as instituições creches e pré-escolas, apresentando como funções 
complementares e indissociáveis da educação infantil o cuidar e o educar, em complementação à ação da família.

No ano de 1997, foi editado o documento Critérios para um atendimento em creches que respeite os direitos fundamentais das crianças, enfatizando a importância da educação infantil na defesa dos direitos das crianças. $\mathrm{O}$ documento apresenta o seguinte quadro de direitos a serem assegurados em creches e pré-escolas:

Nossas crianças têm direito à brincadeira.

Nossas crianças têm direito à atenção individual.

Nossas crianças têm direito a um ambiente aconchegante, seguro e estimulante.

Nossas crianças têm direito ao contato com a natureza.

Nossas crianças têm direito à higiene e à saúde.

Nossas crianças têm direito a uma alimentação sadia.

Nossas crianças têm direito a desenvolver sua curiosidade, imaginação e capacidade de expressão.

Nossas crianças têm direito ao movimento em espaços amplos. Nossas crianças têm direito à proteção, ao afeto e à amizade.

Nossas crianças têm direito a expressar seus sentimentos.

Nossas crianças têm direito a uma especial atenção durante seu período de adaptação à creche.

Nossas crianças têm direito a desenvolver sua identidade cultural, racial e religiosa. (Brasil, 1997, p.11)

A Constituição Federal de 1988, ao dispor sobre a competência da União para legislar sobre as diretrizes e bases da educação nacional, deu início a todo o processo para promulgação da Lei de Diretrizes e Bases da Educação Nacional, Lei n. 9.394/1996, de 20 de dezembro de 1996. O projeto da Lei percorreu os bastidores da Assembleia Constituinte durante oito anos. Segundo Saviani (2000), ocorreram sucessivas versões do Projeto, tanto na Câmara dos Deputados como no Senado, neste último apresentado pelo senador Darcy Ribeiro. Muitos estudos, análises e críticas foram tecidas ao texto da atual LDB, por expressar a adequação da legislação educacional à política educacional neoliberal, implantada no 
Brasil a partir dos anos 1980. Segundo Pereira \& Teixeira (1997, p.90), apesar das limitações ainda presentes, o texto da lei traz uma opção conceitual de educação que projeta uma nova dimensão à formação do homem:

Art. 1- A educação abrange os processos formativos que se desenvolvem na vida familiar, na convivência humana, no trabalho, nas instituições de ensino e pesquisa, nos movimentos sociais e organizações da sociedade civil e nas manifestações culturais. (Brasil, 1996)

Quanto à educação infantil, os autores enfatizam:

A manutenção da educação infantil como primeira etapa da educação básica representa uma grande vitória das forças democráticas, haja vista que foi intenso e polêmico o debate em torno dessa questão, durante o processo de elaboração da lei, ressaltando que, em algumas versões do relatório do Senado Federal, chegou a ser retirada a educação infantil do âmbito da educação básica. (Pereira \& Teixeira, 1997, p.92)

No artigo 2ㅜㅡ a LDB estabelece que a educação é entendida como dever da família e do Estado, devendo inspirar-se nos princípios de liberdade e nas ideias de solidariedade humana, visar ao desenvolvimento pleno do educando, ao seu preparo para o exercício da cidadania e sua qualificação para o trabalho. Propõe uma nova organização para a educação básica, apresentando uma concepção unificada de educação que abrange a formação do indivíduo desde zero ano de idade até o final do ensino médio. A educação básica passa a ser composta de três níveis: educação infantil, ensino fundamental e ensino médio.

$\mathrm{O}$ artigo 4 da referida Lei situa a educação infantil como obrigação do poder público, apesar de não se constituir em um nível obrigatório de ensino, ou seja, não há obrigatoriedade da matrícula das crianças até 5 anos e 11 meses em creches e pré-escolas; em 
contrapartida, há obrigatoriedade de o poder público oferecer esse atendimento.

Segundo o inciso V do artigo 11 da referida Lei, compete ao município a responsabilidade pelo oferecimento da educação infantil e do ensino fundamental:

Art. 11 - V - oferecer a educação infantil em creches e pré-escolas, e, com prioridade, o ensino fundamental, permitida a atuação em outros níveis de ensino somente quando estiverem atendidas plenamente as necessidades de sua área de competência e com recursos acima dos percentuais mínimos vinculados pela Constituição Federal à manutenção e desenvolvimento do ensino. (Brasil, 1996)

A esse respeito, Fullgraf (2001, p.39) alerta sobre a ausência da previsão de fontes de recursos financeiros para a educação infantil, o que tem comprometido a efetivação do direito das crianças à educação. ${ }^{6}$

A educação infantil é reconhecida como primeira etapa da educação básica, devendo ocorrer, segundo o artigo 30, nas modalidades creche (atendimento às crianças de até 3 anos de idade) e pré-escola (atendimento às crianças de 4 a 6 anos de idade). De acordo com esse artigo, as creches passam a integrar o sistema nacional de educação. Os dispositivos legais trazem, ainda, subsídios para a elaboração de uma nova política de educação infantil, até então marcada pelo assistencialismo e por programas de educação compensatória.

A legitimidade da creche como instituição de educação infantil é reafirmada pela $\mathrm{LDB}$, a qual reitera o direito à educação das

6. Em 2007 ocorre a inclusão de creches no Fundeb, resultado de intensa mobilização pelo direito à educação infantil no Brasil realizada por instituições como o Movimento Inter-Fóruns de Educação Infantil, a Rede Nacional pela Primeira Infância e a Campanha Nacional pelo Direito à Educação e a União dos Dirigentes Municipais de Educação (Undime). 
crianças de 0 a 6 anos expressos na Constituição (1988) e no ECA (1990). Segundo o artigo 29, a educação infantil deverá favorecer o pleno desenvolvimento das crianças, sendo oferecida como complemento, e não em substituição à educação da família:

Art. 29 - A educação infantil, primeira etapa da educação básica, tem como finalidade o desenvolvimento integral da criança até seis anos de idade, em seus aspectos físicos, psicológicos, intelectuais e sociais, complementando a ação da família e da comunidade. (Brasil, 1996)

Para Angotti (2006, p.18-9), o artigo 29 revela as prerrogativas de uma educação infantil que anuncia o direito da criança ao seu desenvolvimento, "porém não se poderá prescindir de uma ação integrada entre diferentes perspectivas advindas de políticas outras, tais como de ação social, de saúde, de cultura".

O artigo 31 da Lei estabelece que a avaliação na educação infantil aconteça através do acompanhamento e registro do desenvolvimento da criança, sem objetivar a promoção ao ensino fundamental. Nesse artigo, rompe-se com os propósitos da educação infantil preparatória, suscitando novas práticas à pedagogia da infância.

No ano de 1998 foi elaborado e publicado o documento Subsídios para o credenciamento e o funcionamento das instituições de educação infantil, com o intuito de contribuir para a formulação de diretrizes e normas para as instituições de educação. A elaboração desse documento contou com a participação de representantes do Conselho de Educação, consultores e especialistas da educação infantil.

No mesmo ano, o Ministério da Educação e Cultura publicou, em três volumes, o Referencial Curricular Nacional para a Educação Infantil, constituindo-se apenas de um conjunto de sugestões e subsídios para os professores de creches e pré-escolas.

O primeiro volume, denominado Introdução, discute conceitos importantes em relação à educação infantil, como a criança, cuidar e educar, brincar, relação creche-família, a educação de crianças com necessidades especiais, a instituição e o projeto educativo. 
O segundo volume, intitulado a Formação pessoal e social da criança, aborda os processos de construção da identidade e autonomia das crianças, e o terceiro, denominado Conhecimento do mundo, discute os diferentes conteúdos a serem trabalhados na educação infantil. Nesse volume são apresentados seis eixos para as propostas curriculares das instituições de educação infantil: música, movimento, artes visuais, linguagem oral e escrita, natureza e sociedade e matemática.

Algumas críticas foram tecidas à elaboração dos referenciais por apresentar um modelo homogêneo e escolarizante de educação infantil, como esclarece Fullgraf (2001, p.71):

A publicação e distribuição do documento "Referencial Nacional para Educação Infantil”, vol. 1, 2, 3/RCNEI, que para muitos pesquisadores da área é um retrocesso, traz de forma implícita uma concepção de educação compensatória e escolarizante, além de considerar a criança numa perspectiva de sujeito universal. Importa observar que a descontinuidade das políticas para educação infantil vem marcada pela inserção da influência neoliberal subjacente aos documentos internacionais. Destaca-se que esses referenciais ao invés de transformar um novo paradigma curricular em realidade, impõe este paradigma.

Considerando o ordenamento legal, no qual tem se baseado a política de educação das crianças de 0 a 6 anos no Brasil, especialmente a partir da década de 1980, deu-se, em 1999, a aprovação das Diretrizes Curriculares Nacionais para a Educação Infantil.

Segundo Leite Filho (2001), no parecer 22/98 relatado e aprovado pela conselheira professora Regina Alcântara de Assis, do Conselho Nacional de Educação, o qual antecede a elaboração das diretrizes, é feita uma alusão a uma política ainda não definida no país: "Uma política nacional, que se remeta à indispensável integração do Estado e da sociedade civil, como co-participantes das famílias no cuidado e educação de seus filhos entre 0 a 6 anos, ainda não está definida no Brasil" (Brasil, 1998 apud Leite Filho, 2001, p.42). 
As Diretrizes Curriculares Nacionais para a Educação Infantil, de caráter mandatário, propuseram novas demandas para as instituições da área, especialmente em relação às orientações curriculares e à elaboração de seus projetos pedagógicos. $\mathrm{O}$ referido documento, em seu artigo $3^{\circ}$, incisos de I a VIII, estabelece as diretrizes, princípios, fundamentos e procedimentos que deverão orientar as instituições de educação infantil quanto à organização, articulação, desenvolvimento e avaliação de suas propostas pedagógicas:

I - As Propostas Pedagógicas das Instituições de Educação Infantil devem respeitar os seguintes Fundamentos Norteadores;

a) Princípios Éticos da Autonomia, da Responsabilidade, da Solidariedade e do Respeito ao Bem Comum;

b) Princípios Políticos dos Direitos e Deveres de Cidadania, do Exercício da Criticidade e do Respeito à Ordem Democrática;

c) Princípios Estéticos da Sensibilidade, da Criatividade, da Ludicidade e da Diversidade de Manifestações Artísticas e Culturais.

II - As Instituições de Educação Infantil ao definir suas Propostas Pedagógicas deverão explicitar o reconhecimento da importância da identidade pessoal de alunos, suas famílias, professores e outros profissionais e a identidade de cada Unidade Educacional, nos vários contextos em que se situem.

III - As Instituições de Educação Infantil devem promover em suas propostas pedagógicas práticas de educação e cuidados, que possibilitem a integração entre os aspectos físicos, emocionais, afetivos e cognitivos/linguísticos e sociais da criança, entendendo que ela é um ser completo, total e indivisível.

IV - As Propostas Pedagógicas das Instituições de Educação Infantil, ao reconhecerem as crianças como seres íntegros, que aprendem a ser e conviver consigo próprios, com os demais e o próprio ambiente de maneira articulada e gradual, devem buscar, a partir de atividades intencionais, em momentos de ações, ora estruturadas, ora espontâneas e livres, a interação entre as di- 
versas áreas de conhecimento e aspectos da vida cidadã, contribuindo assim para o provimento de conteúdos básicos para a constituição de conhecimentos e valores.

V - As Propostas Pedagógicas para a Educação Infantil devem organizar suas estratégias de avaliação, através do acompanhamento e dos registros de etapas alcançadas nos cuidados e na educação para crianças de 0 a 6 anos, "sem o objetivo de promoção, mesmo para o acesso ao ensino fundamental".

VI - As propostas pedagógicas das Instituições de Educação Infantil devem ser criadas, coordenadas, supervisionadas e avaliadas por educadores, com, pelo menos, o diploma de Curso de Formação de Professores, mesmo que da equipe de Profissionais participem outros das áreas de Ciências Humanas, Sociais e Exatas, assim como familiares das crianças. Da direção das instituições de Educação Infantil deve participar, necessariamente, um educador com, no mínimo, o Curso de Formação de Professores.

VII - O ambiente de gestão democrática por parte dos educadores, a partir de liderança responsável e de qualidade, deve garantir direitos básicos de crianças e suas famílias à educação e cuidados, num contexto de atenção multidisciplinar com profissionais necessários para o atendimento.

VIII - As Propostas Pedagógicas e os regimentos das Instituições de Educação Infantil devem, em clima de cooperação, proporcionar condições de funcionamento das estratégias educacionais, do uso do espaço físico, do horário e do calendário escolar, que possibilitem a adoção, execução, avaliação e o aperfeiçoamento das diretrizes. (Brasil, 1999)

Conforme as Diretrizes Curriculares Nacionais para a Educação Infantil, as creches e pré-escolas são reconhecidas como espaços de construção da cidadania infantil, onde as ações cotidianas junto às crianças devem, sobretudo, assegurar seus direitos fundamentais, subsidiadas por uma concepção ampla de educação e no questionamento constante sobre que educação queremos para nossas crianças hoje e no futuro. Os espaços institucionais devem ser espaços acolhedores, seguros, estimuladores, oportunizando 
aprendizagens e experiências múltiplas, respeitando as crianças em suas capacidades, necessidades e contribuindo para o desenvolvimento de suas potencialidades.

As propostas pedagógicas, pautadas nos princípios éticos, políticos e estéticos, contemplam o compromisso da educação infantil com a educação social das crianças, no desenvolvimento de relações afetivas e na construção dos sentimentos de respeito, compreensão e solidariedade fundamentais para uma sociedade mais humana $e$ democrática.

Apresenta a necessidade de reconstrução da relação entre as famílias e as instituições de educação infantil, que historicamente foi permeada por uma concepção assistencialista, gerando ações preconceituosas e discriminatórias.

Ao reconhecer a importância da qualidade do atendimento das instituições de educação infantil, as Diretrizes Curriculares reafirmam a necessidade de qualificação dos profissionais envolvidos no trabalho educativo com as crianças, pois, para transformar espaços institucionais em espaços de exercício da cidadania das crianças é necessário que os profissionais estejam qualificados para a defesa e promoção dos direitos da infância.

Em 2000, o Conselho Nacional de Educação e a Câmara da Educação Básica aprovaram o Parecer n. 4/2000, o qual preconiza as Diretrizes Operacionais para a Educação Infantil, que trata de aspectos normativos para a educação infantil:

Tais aspectos são relevantes em virtude da Educação Infantil, reconhecida como etapa inicial da Educação Básica, guardar especificidades em relação aos demais níveis de ensino, que se traduz na indissociabilidade das ações de educar e cuidar em todos os âmbitos de atuação, o que inclui desde uma concepção de responsabilidade compartilhada entre família e poder público, definição de tipos de instituições, volume de serviços oferecidos, horários de funcionamento, até as ações que se desenvolvem diretamente com as crianças. Essa especificidade implica na construção de uma identidade própria à educação 
infantil que reconhece, conjuntamente, as necessidades e interesses das crianças e suas famílias no contexto da modernidade. (Brasil, 2000, p.2)

A LDB e a Constituição Federal prescreveram a obrigatoriedade da elaboração do Plano Nacional de Educação (PNE), aprovado pela Lei n. 10.172, de 9 de janeiro de 2001.

Segundo o artigo 214 da Constituição, "a lei estabelecerá o Plano Nacional de Educação, de duração plurianual, visando a articulação e o desenvolvimento do ensino em seus diversos níveis e a integração das ações do poder público".

A LDB, em seu artigo 9o, apresenta como responsabilidade da União elaborar o Plano Nacional de Educação em colaboração com os estados, o Distrito Federal e os municípios.

Saviani (2000, p.3) assim apresenta a importância de um PNE na organização do sistema educacional:

A importância do Plano Nacional de Educação deriva de seu caráter global, abrangente de todos os aspectos concernentes à organização da educação nacional, e de seu caráter operacional, implicando na definição das ações, traduzidas em metas a serem atingidas em prazos determinados, dentro do limite global de tempo abrangido pelo plano, que a própria LDB definiu para um período de dez anos.

Cabe destacar que a elaboração e promulgação do PNE esteve em consonância com as legislações nacionais e compromissos internacionais firmados pelo Brasil, dentre eles a Conferência de Dacar ${ }^{7}$ sobre a Educação para Todos, promovida pela Unesco em 2000.

7. Uma das seis metas expressas no Marco de Ação de Dacar, proposto no Fórum de Educação para Todos, realizado em abril de 2000, no Senegal, do qual o Brasil é um dos signatários, foi a de ampliar a oferta e melhorar a qualidade da educação e dos cuidados na primeira infância, com especial atenção às crianças em situação de vulnerabilidade. 
O PNE estabelece as diretrizes, objetivos e metas para cada nível do ensino brasileiro a serem atingidos no prazo de dez anos (2001-2010). Para a eficácia de sua aplicabilidade, o plano deverá ser desdobrado em planos estaduais e municipais atendendo às especificidades de cada estado e região do país bem como à integração e à continuidade das políticas educacionais no Brasil.

Estabelece como objetivos e prioridades:

- a elevação global do nível de escolaridade da população;

- a melhoria da qualidade do ensino em todos os níveis;

- a redução das desigualdades sociais e regionais no tocante ao acesso e à permanência, com sucesso, na educação pública e

- democratização da gestão do ensino público, nos estabelecimentos oficiais, obedecendo aos princípios da participação dos profissionais da educação na elaboração do projeto pedagógico da escola e a participação das comunidades escolar e local em conselhos escolares ou equivalentes. (Brasil, 2001)

O PNE reconhece a importância da educação infantil para a formação da personalidade e desenvolvimento da criança. Estabelece um conjunto de 26 metas versando sobre a ampliação da oferta do atendimento nas instituições de educação infantil, o estabelecimento de padrões de infraestrutura para creches e pré-escolas, a implantação de um programa nacional de formação dos profissionais da educação infantil, o fornecimento de materiais pedagógicos necessários ao trabalho educacional com as crianças, dentre outras.

Consideramos pertinente a citação da primeira meta referente à ampliação da oferta do atendimento, visto que o acesso a essa questão, aliada à qualidade, tem sido apontada por muitos estudiosos da educação infantil brasileira como um dos pontos cruciais para a discussão dos direitos educacionais das crianças no país.

1. Ampliar a oferta de educação infantil de forma a atender, em cinco anos, a $30 \%$ da população de até 3 anos de idade e $60 \%$ da 
população de 4 e 6 anos (ou 4 e 5 anos) e, até o final da década, alcançar a meta de $50 \%$ das crianças de 0 a 3 anos e $80 \%$ das de 4 e 5 anos. (Brasil, 2001)

Apesar das metas estabelecidas pelo PNE, o quadro atual de atendimento da educação infantil está aquém das necessidades do país.

O Brasil tem atualmente o total de 1,7 milhão de crianças na faixa etária de 0 a 3 anos de idade e, desse total, 15,5\% frequentam creches. O percentual de frequência difere em relação a alguns indicadores, como gênero, classe social, etnia e região do país. Segundo dados do IBGE (2008), a região Norte do país apresenta o menor índice de atendimento em creches, visto que apenas $8 \%$, ou seja, o total de 2 milhões de crianças têm acesso às creches. Em relação à pré-escola, os resultados são melhores, embora ainda não tenham atingido o proposto pelo PNE. No país, a cobertura do atendimento às crianças de 4 a 6 anos atinge 7 milhões de crianças, o que representa $76 \%$ de meninas e meninos matriculados em pré-escola. Considerando a meta, segundo dados do IBGE (2008), 2,2 milhões de crianças nessa faixa etária estão fora da escola e, desse número, 58\% são crianças negras, o que confirma o caráter excludente do sistema educacional brasileiro desde a educação infantil.

A Secretaria de Educação Básica do Ministério da Educação e Cultura, por meio da Coordenação Geral de Educação Infantil (Coedi) e do Departamento de Políticas de Educação Infantil do Ensino Fundamental (DPE), apresentaram em 2006 o documento Parâmetros Nacionais de Qualidade para a Educação Infantil. Esse documento, assim como os demais publicados pelo MEC, responde ao papel desse ministério como indutor e proponente de diretrizes para a educação nacional e, consequentemente, para a educação infantil.

A elaboração dos Parâmetros Nacionais de Qualidade para a Educação Infantil foi resultante da contribuição de conselheiros e técnicos do Ministério da Educação, bem como de professores, profissionais e especialistas da educação infantil, respondendo a 
um dos propósitos do Plano Nacional de Educação previsto no capítulo II, item 19, do tópico Objetivos e Metas para Educação Infantil: "Estabelecer parâmetros de qualidade dos serviços de educação infantil como referência para a supervisão, o controle e avaliação, e como instrumento para a adoção das medidas de melhoria da qualidade" (Brasil, 2001).

A versão final do documento foi discutida em etapas preliminares debatidas em seminários regionais e técnicos promovidos pela Secretaria de Educação Básica, pelo Departamento de Políticas de Educação Infantil do Ensino Fundamental, e pela Coordenação Geral de Educação Infantil, em 2004 e 2005.

O documento apresenta como objetivo principal o estabelecimento de padrões de referência no tocante à organização e funcionamento das instituições de educação infantil. Quanto ao estabelecimento de padrões, o documento especifica:

[...] Sublinhamos que a finalidade de definir os parâmetros de qualidade se realiza neste documento de modo a estabelecer não um padrão mínimo, nem um padrão máximo, mas os requisitos necessários para uma educação infantil que possibilite o desenvolvimento integral da criança até os cinco anos de idade, em seus aspectos físicos, psicológicos, intelectual e social. (Brasil, 2006, v.1, p.9)

O primeiro volume discorre sobre aspectos importantes para uma definição de parâmetros de qualidade para a educação infantil, apresentando uma concepção de criança, de pedagogia da educação infantil, as principais tendências identificadas em pesquisas recentes dentro e fora do país, os desdobramentos previstos na legislação nacional para a área e consensos e polêmicas no campo. $\mathrm{O}$ segundo volume engloba aspectos pertinentes às competências dos sistemas de ensino e a caracterização das instituições de educação infantil a partir de definições legais.

Em 2006, foram publicados os documentos Parâmetros Nacionais de Infraestrutura para as Instituições de Educação Infantil e 
Parâmetros Básicos de Infraestrutura para Instituições de Educação Infantil.

Ainda no ano de 2006, o MEC apresentou o documento Política Nacional de Educação Infantil: pelo direito da criança de 0 a 6 anos à Educação, contendo diretrizes, objetivos, metas e estratégias a serem alcançadas pelas instituições de educação infantil. $\mathrm{O}$ documento destaca a necessidade da indissociabilidade entre cuidar $e$ educar, o papel complementar das instituições de educação infantil à educação familiar, o direito da criança à educação infantil, a inclusão de crianças com necessidades especiais e o brincar como forma privilegiada de a criança conhecer o mundo e a formação de professores.

\section{Representações sobre os direitos da infância: a educação e o brincar}

A trajetória das leis e dos documentos oficiais que regem a educação infantil no país demonstra que muitos avanços foram conquistados para que a educação infantil fosse reconhecida no quadro das políticas públicas, porém muitos desafios ainda se fazem presentes para que seja oferecida uma educação infantil de qualidade às crianças brasileiras.

No que se refere a esse aspecto, pesquisas e debates apontam a relevância da garantia do acesso à educação infantil e da formação de seus profissionais para que tenhamos uma educação infantil que assegure a condição da criança como sujeito de direitos.

Quanto à formação dos profissionais, a LDB enfatiza a necessidade de formação, no mínimo, no Magistério e, preferencialmente, no nível superior, em curso de formação de professores. Considerando a discussão da formação desses profissionais, destacamos a importância de que os mesmos conheçam o quadro legal referente à educação infantil.

Ao entrevistarmos as educadoras quanto ao conhecimento do quadro legal que rege a educação infantil, embora afirmassem co- 
nhecimento, responderam de forma bastante superficial a respeito do assunto:

Eu já ouvi falar sobre o ECA, já ouvi falar sim, mas os objetivos agora não sei. (Rosa)

O ECA, conheço algumas delas. Preciso conhecer mais. A LDB eu conheço. (Íris)

Eu não guardo as leis. [...] eu conheço estes direitos e às vezes eu não guardo eles na cabeça, mas no fundo eu sei o que a criança precisa seja no físico, emocional... (Gardênia)

Cury discute a necessidade de os profissionais da educação conhecerem o quadro legal para que seja rompida a distância entre o proclamado e o efetivado em nossas legislações.

Você é um educador ou uma educadora, um profissional do ensino ou um trabalhador da educação. Você é um administrador da educação ou um político, e pode ser também um interessado em educação. No exercício de suas funções, você quer ser um profissional consciente, crítico e competente. Para tanto, várias dimensões são exigidas: formação, conhecimentos, habilidades, competências e valores. Digamos que, entre os conhecimentos necessários, um que você precisa dominar é o ordenamento normativo de seu campo profissional, de seu campo de interesse e de sua sociedade. (Cury, 2002, p.9)

Podemos afirmar que é fundamental que os profissionais da educação infantil conheçam o quadro normativo sobre os direitos da infância, em especial quanto ao direito à educação infantil.

Quanto ao quadro normativo, nenhuma das entrevistadas fez referência às Diretrizes Curriculares Nacionais da Educação Infantil, que se constituem num documento mandatário para a elaboração das propostas pedagógicas das creches e pré-escolas. 
Outro aspecto, revelado nas entrevistas, é a ausência da discussão do direito da criança a uma educação de qualidade. Pesquisas recentes têm focado a importância da qualidade nos serviços das instituições de educação infantil, o que diz respeito, sobretudo, ao reconhecimento da condição da criança como sujeito de direitos e à formação dos profissionais para a efetivação das reformas legais e institucionais.

Campos, Fullgraf \& Wiggers (2006), ao discutirem a qualidade da educação infantil brasileira, apresentaram os resultados de um estudo realizado, no período de 1996 a 2003, nos principais periódicos de educação discutidos nas Reuniões Anuais da Associação Nacional de Pesquisa em Educação. As autoras asseveram que:

[...] no atual cenário da educação infantil no Brasil destaca-se que os marcos legais estão postos e sua divulgação encontra-se em andamento, ainda que de forma desigual nos diversos contextos do país. Apesar das grandes diferenças regionais que caracterizam a realidade social brasileira observam-se, no entanto, alguns padrões comuns registrados nas pesquisas que indicam a persistência de modelos de atendimento para creches e pré-escolas bastante resistentes à introdução das mudanças definidas na nova legislação. (Campos, Fullgraf \& Wiggers, 2006, p.117)

O documento Parâmetros Nacionais de Qualidade para a Educação Infantil discute a importância de que seja revista a concepção de criança e de pedagogia da educação infantil para o alcance de novos patamares de qualidade no trabalho das instituições de educação infantil. No documento é enfatizada a visão da criança como um sujeito ativo, que constrói conhecimentos em interação com o mundo social, com os adultos e com seus pares. O desenvolvimento da criança apresenta características em permanentes transformações, cujas mudanças são processadas qualitativa e quantitativamente. Dessa forma, a educação da criança pequena apresenta certas especificidades, como afirma Rocha: 
Enquanto a escola tem como sujeito o aluno, e como objeto fundamental o ensino nas diferentes áreas da aula; a creche e a pré-escola têm como objeto as relações educativas travadas num espaço de convívio que tem como sujeito a criança de 0 até 6 anos de idade. (Rocha, 1999 apud Brasil, 2006, p.17)

No questionário aplicado às educadoras das creches de Franca, ao serem indagadas quanto aos direitos que consideravam mais importantes no trabalho com as crianças, 39,62\% das entrevistadas afirmaram ser a educação. A seguir foram elencados os direitos: a alimentação, 28,3\%; o lúdico e o lazer, 16,98\%, a saúde, $11,33 \%$ e a liberdade de expressão, 3,77\%.

O documento Critérios para um atendimento em creches que respeite os direitos fundamentais das crianças (Brasil, 1997), ao estabelecer critérios relativos à organização, ao funcionamento das creches e às práticas desenvolvidas no trabalho com as crianças, destaca em relação ao direito das crianças à alimentação (p.18): a importância da qualidade dos alimentos oferecidos às crianças; o respeito às preferências e hábitos alimentares; o desenvolvimento da autonomia das crianças nos momentos de refeições; a organização e limpeza do ambiente onde ocorrem as refeições e a necessidade de as famílias serem informadas sobre a alimentação oferecida às crianças. Em relação ao direito da criança à brincadeira (p.12), o documento considera os seguintes aspectos: a importância de as crianças terem acesso aos brinquedos, a necessidade da organização dos espaços para o acontecimento das brincadeiras, a importância da participação dos adultos nas brincadeiras, a flexibilidade das rotinas e do tempo livre para que as brincadeiras aconteçam, e que as famílias deverão receber orientações sobre a importância das brincadeiras para o desenvolvimento infantil.

Em relação ao direito da criança à saúde nas instituições de educação infantil (Brasil, 1997, p.17), o documento aborda a importância de as crianças aprenderem os cuidados referentes à sua higiene e saúde, a necessidade da higiene do ambiente físico da instituição, o controle sistemático sobre o desenvolvimento físico das 
crianças e o atendimento às crianças com dificuldades especiais. No que se refere ao direito à liberdade de expressão (Brasil, 1997, p.19), o documento enfatiza os direitos de as crianças manifestarem sua curiosidade, desenvolverem a imaginação, participarem de atividades que possibilitem a expressão das múltiplas linguagens, como dançar, cantar, ouvir histórias, desenhar, pintar, etc. Dentre os critérios é destacada a importância de que não sejam reprimidas as curiosidades das crianças em relação ao seu corpo e à sua sexualidade.

Com a realização das entrevistas buscamos compreender melhor a representação das educadoras sobre o direito das crianças à educação. Embora evocassem um discurso acerca do direito da criança à educação, a visão preponderante é a de uma educação preparatória, focada no ensino, em que a criança é vista como aluno e não como o sujeito desse espaço institucional.

A educação aqui, o que a gente visa é a educação, o bem-estar, lazer e segurança são os básicos que a gente oferece aqui.

Eu acredito que a educação é a base de tudo. Se a gente não trabalhar a educação agora, isso no futuro vai ficar muito vago na criança. (Rosa)

[...] a hora principal é a hora da atividade, às 9 h é hora da atividade, quando tem o projeto, você dá atividade e precisa de muita atenção. (Angélica)

Eu nunca ouvi uma reclamação aqui sobre a criança ter passado alguma necessidade, então acho que é muito importante para ela, porque desde assim, desde o começo, assim de 0 até 5 anos ela fica aqui é uma parte muito importante da vida dela. Antigamente não era, antigamente a creche eles vinham era para deixar as crianças, e depois buscava era tipo um depósito de criança, agora não, agora é totalmente diferente; agora aqui ela começa a ter uma noção da vida, a ter uma noção de ensino, então é um direito [...]. Agora está investindo mais na educação e é o que tem que acontecer porque a coisa mais importante que tem no 
mundo é a saúde e a educação, coisas que estão faltando muito. A educação é um dos principais, imagina se não tivesse a creche, quem ia estar com estas crianças, onde que elas iriam ficar? (Angélica)

Observa-se nesse último discurso uma visão de creche que, embora tenha mudado historicamente, ainda se configura em um espaço de abrigo das crianças em substituição à ausência das famílias.

Os discursos dessas educadoras enfatizam o desenvolvimento de atividades como característica de uma proposta educativa, porém não evidenciam os aspectos relevantes dessas atividades e nem quais seus objetivos. A sistematização de uma rotina revela a preocupação com um modelo educacional próximo ao escolar.

[...] agora está mudando o jeito, agora tem que fazer planejamento, agora tem que fazer sequência didática e antes não tinha nada disto, então a gente vê que é para melhor que está mudando. (Angélica)

[...] a gente faz o planejamento todo o começo do ano, mas é bem flexível para as mudanças porque a gente não sabe como as crianças vão vir, mas tem lá o planejamento, os projetos, as atividades sequenciadas. (Gardênia)

[...] antes de inciar o trabalho a gente passa para a pedagoga dar uma olhada. Se estiver tudo certo a gente inicia. Temos uma folha de rotina semanal onde distribuímos as atividades da semana, por exemplo, para não ficar cansativo só atividade de história a gente intercala com outra atividade. [...] assim como o planejamento ele tem que ser oferecido, ele tem que ser seguido. (Dália)

[...] como eu trabalho com crianças de dois anos nós elaboramos projetos, nós desenvolvemos atividades, nós tentamos aplicar as atividades. [...] agora com a faixa etária de um ano eu 
acho que é mais o cuidado, não tem como trabalhar o pedagógico não. (Rosa)

O educar é compreendido como uma tendência escolarizante e não está articulado ao cuidar. A ideia de que a educação infantil é o alicerce da escolaridade futura é presente na fala desta educadora ao referir-se à dimensão pedagógica da educação infantil:

O pedagógico eu acho que é a alfabetização, a criança tem que ser preparada para os outros anos. (Rosa)

A história revela que a trajetória das instituições de educação infantil no país é marcada pela polarização entre o assistir e o educar. As creches surgem como instituições assistenciais para o amparo, proteção e guarda das crianças pobres e abandonadas, visando ao combate da mortalidade infantil e à moralização das famílias empobrecidas. Ao contrário, as pré-escolas desde o início são dotadas de funções educativas destinadas inicialmente às crianças da elite, e depois democratizadas às demais classes sociais por meio do atendimento em instituições públicas.

Para Kuhlmann Júnior, ambas as instituições sempre foram educativas e o recorte institucional deve-se à destinação social da clientela atendida. Alerta para o fato de que muitas vezes é apresentado um discurso educacional, porém as práticas institucionais continuam reproduzindo uma concepção educacional assistencialista:

A polaridade entre assistência e educação, representando o mal e o bem, como em um conto de fadas, permite às propostas inaugurar o novo e implantar o pedagógico ou o educacional, nos textos..., enquanto a realidade institucional permanece intocada nas questões que efetivamente discriminam a população pobre. (Kuhlmann Júnior, 2000b, p.53) 
Atualmente, creches e pré-escolas são elencadas como pertencentes ao primeiro nível da educação básica do sistema educacional brasileiro, devendo, concomitantemente, exercerem as funções de cuidar e educar. O debate sobre essas funções vem sendo travado desde 1994 no país no âmbito do Ministério da Educação, com a publicação da Política Nacional de Educação Infantil.

As Diretrizes Curriculares Nacionais para a Educação Infantil dispõem no artigo 3ำ, inciso III, que as propostas pedagógicas de creches e pré-escolas devem promover "práticas de educação e cuidados que possibilitem a integração entre os aspectos físicos, emocionais, afetivos, cognitivo, linguístico e sociais da criança, entendendo que ela é um ser completo, total e indivisível".

É importante destacarmos que, embora o cuidar e o educar sejam contemplados como funções indissociáveis na educação infantil, são funções importantes e necessárias para todas as etapas da educação do ser humano.

Podemos partir da compreensão do cuidar como uma dimensão integrante da proposta pedagógica das instituições de educação infantil. O cuidar se expressa através de procedimentos específicos em relação ao outro, com base em conhecimentos variados das ciências e também por crenças e valores em relação ao desenvolvimento infantil.

O cuidar deve favorecer e contribuir para que o outro se desenvolva como ser humano. Implica compromisso e afeto.

Para cuidar é preciso antes de tudo estar comprometido com o outro, com sua singularidade, ser solidário com suas necessidades, confiando em suas capacidades. Disso depende a construção de um vínculo entre quem cuida e quem é cuidado. (Brasil, 1998, v.1, p.25)

No trabalho pedagógico, o cuidar das crianças pequenas significa atender às suas necessidades físicas e biológicas, como a troca de fraldas, a alimentação, atender às suas necessidades de segu- 
rança (espaço tranquilo, seguro em relação a possíveis acidentes) e necessidades afetivas.

O cuidado com as crianças, ou seja, o compromisso em assegurar o seu desenvolvimento, se manifesta, ainda, na maneira como o professor organiza o trabalho pedagógico, prepara uma atividade, disponibiliza os materiais que serão utilizados pelas crianças, planeja os espaços destinados às brincadeiras, enfim, como organiza o tempo e o espaço na rotina das instituições de educação infantil.

Em relação ao educar, é importante pontuarmos que na educação infantil o educar acontece em um momento específico do desenvolvimento e da educação do ser humano, portanto deve-se considerar a especificidade da ação educativa para o desenvolvimento das crianças.

As Diretrizes Curriculares Nacionais para a Educação Infantil estabelecem no inciso IV:

[...] as propostas pedagógicas das instituições de educação infantil, ao reconhecerem as crianças como seres íntegros, que aprendem a ser e a conviver consigo próprios, com os demais e com o próprio ambiente de maneira articulada e gradual, devem buscar, a partir de atividades intencionais, em momentos de ações, ora estruturadas, ora espontâneas e livres, a interação entre as diversas áreas de conhecimento e aspectos da vida cidadã, contribuindo assim com o provimento de conteúdos básicos para a constituição de conhecimentos e valores. (Brasil, 1999)

Dessa forma, podemos compreender que o educar implica a elaboração de atividades educativas contextualizadas e intencionais direcionadas ao desenvolvimento das crianças.

Segundo Oliveira (2005, p.48), a atividade educativa como ação intencional deve ser orientada para a ampliação do universo cultural das crianças, possibilitando uma compreensão da realidade e, consequentemente, uma ação transformadora sobre a mesma.

O educar, de acordo com o Referencial Curricular Nacional para a Educação Infantil, pode ser compreendido como: 
Educar significa, portanto propiciar situações de cuidados, brincadeiras e aprendizagens orientadas de forma integrada e que possam contribuir para o desenvolvimento das capacidades infantis de relação interpessoal, de ser e estar com os outros em uma atitude básica de aceitação, respeito e confiança, e o acesso, pelas crianças, aos conhecimentos mais amplos da realidade social e cultural. Neste processo, a educação poderá auxiliar o desenvolvimento das capacidades de apropriação e conhecimento das potencialidades corporais, afetivas, emocionais, estéticas e éticas, na perspectiva de contribuir para a formação de crianças felizes e saudáveis. (Brasil, 1998, v.1, p.23)

Reconhecer a legitimidade de creches e pré-escolas como instituições educativas e a educação infantil enquanto etapa inicial da educação básica implica o reconhecimento dessas instituições como espaços com funções próprias e específicas, e não meramente como espaços para suprirem carências ou "preparatórios" para as etapas de educação subsequentes.

Ao pensarmos na elaboração dos conteúdos curriculares na educação infantil, tão ou mais importante que buscarmos respostas sobre o que ensinar é o questionamento sobre como esses conteúdos e conhecimentos contribuirão no desenvolvimento e na vida das crianças. Esse fato requer a discussão da dimensão pedagógica e política das propostas pedagógicas das instituições de educação infantil.

Kramer (2003b), ao discutir a questão do projeto político pedagógico na educação infantil, chama a atenção para a compreensão dos conceitos de político e de pedagógico.

A dimensão política, segundo a autora, refere-se à garantia de um atendimento educacional de qualidade a todas as crianças, independentemente de sua classe social. Significa a opção em atuar contra as desigualdades, reconhecendo as diferenças, sejam elas étnicas, religiosas, de gênero, etc. 
[...] todo projeto de educação infantil deve afirmar a igualdade, entendendo que as crianças também as de zero a seis anos são cidadãos de direitos, têm diferenças que precisam ser reconhecidas e pertencem a diversas classes sociais, vivendo na maioria das vezes uma situação de desigualdade que precisa ser superada. (Kramer, 2003b, p.55)

Em relação ao pedagógico, a autora destaca a importância do aspecto cultural, reconhecendo a criança como sujeito da história e da cultura.

O trabalho pedagógico em educação infantil, da maneira como o entendo, não precisa ser feito sentado em carteiras, o que caracteriza o trabalho pedagógico é a experiência com o conhecimento científico e com a literatura, a música, a dança, o teatro, o cinema, a produção artística, histórica e cultural que se encontra nos museus, a arte. Esta visão do que é pedagógico ajuda a pensar um projeto que não se configura como escolar, feito apenas na sala de aula. O campo pedagógico é interdisciplinar, inclui as dimensões ética e estética. (Kramer, 2003b, p.60)

A organização curricular das instituições de educação infantil precisa considerar a construção de uma proposta pedagógica que, ao favorecer o desenvolvimento e a aprendizagem infantil, contemple a formação dos profissionais envolvidos nos cuidados e educação das crianças e promova a participação efetiva das famílias no projeto pedagógico das instituições.

Novamente é preciso destacar que as convicções, os valores e as opções teórico-metodológicas dos adultos serão significativos no rumo de determinada organização curricular, pois, conforme afirmam Dalhberg, Moss \& Pence (2003, p.87), “o que pensamos serem estas instituições determina o que fazemos e o que acontece dentro delas".

Assim, é preciso que se pense em atividades contextualizadas em uma rotina dinâmica compromissada com os direitos da infância. 
Oliveira (2005, p.227) propõe uma organização curricular para a educação infantil baseada na articulação de três eixos: o trabalho pedagógico com múltiplas linguagens, o jogo como recurso privilegiado de desenvolvimento da criança pequena e a pedagogia de projetos didáticos.

Com a aplicação do questionário tivemos presente um quadro de evocações que revelaram majoritariamente uma concepção de educação infantil que proporcione às crianças descoberta, aprendizagem, interação, estimulação e desenvolvimento. Estas foram as evocações manifestadas por 18 das entrevistadas, totalizando o percentual de 34\%. Outro grupo de evocações foram as atividades lúdicas e prazerosas, presentes nas representações de 14 educadoras, o que significa $26,4 \%$ dos sujeitos entrevistados. A visão de educação infantil preparatória, representada pela palavra alicerce foi manifestada por seis educadoras, ou seja, por 11,3\% das entrevistas, seguida pela palavra direito, manifestada por quatro educadoras, totalizando $7,5 \%$.

$\mathrm{Na}$ Tabela 4 podemos visualizar o quadro de representações sobre as funções da educação infantil.

Em contrapartida, nas entrevistas foi revelado um discurso majoritário sobre a concepção da educação infantil como alicerce e fase preparatória para a escolaridade futura:

[...] a criança quando ela sai do período de 6 anos, tudo aquilo que ela passou é muito válido para a vida dela, depois que ela sai da creche, assim é muito válido na escola mesmo. [...] imagina se não tivesse a creche, quem ia estar com estas crianças, onde que elas iam estar. Você pode pegar uma criança que fica na creche e uma criança que fica em casa, não são todos os pais que leem, que cantam, que dão atenção, que ensinam o básico para as crianças, ... então eu acho isso. (Angélica)

Primeira etapa da educação básica. Esta etapa é superimportante porque quando a criança chega na pré-escola, na primeira série, a criança que já passou pela educação infantil, ela tem muito 
Tabela 4 - Funções da educação infantil

\begin{tabular}{|l|c|c|}
\hline \multicolumn{1}{|c|}{ Funções } & Total de sujeitos & Porcentagem \\
\hline $\begin{array}{l}\text { Descoberta, aprendizagem, interação, } \\
\text { estimulação } \\
\text { e desenvolvimento }\end{array}$ & 18 & $34,0 \%$ \\
\hline Atividades lúdicas e prazerosas & 14 & $26,4 \%$ \\
\hline Atenção e afeto & 11 & $20,8 \%$ \\
\hline Alicerce & 6 & $11,3 \%$ \\
\hline Direito & 4 & $7,5 \%$ \\
\hline Total & 53 & $100 \%$ \\
\hline
\end{tabular}

mais possibilidade de aprender. Eu acho é... como se fosse uma aprendizagem. (Íris)

Eu acho que é a fase mais importante da criança porque ela está formando os seus conceitos, os seus valores para um futuro adolescente, para um futuro jovem adulto, eu acho que aqui é a base, é o alicerce de um futuro adulto. (Dália)

Uma das fases mais importantes na vida de uma pessoa porque daí que você tem base, você se torna autônoma, você consegue assim, já ir fazendo coisas sozinhas, então é uma das fases mais importantes. (Rosa)

Como podemos constatar, as representações dessas educadoras sobre o conceito de educação infantil expressam uma visão reducionista da educação das crianças e ao mesmo tempo condizente com os propósitos dos organismos internacionais, no sentido de formar o "sujeito útil". Trazem também a ideia da creche enquanto instituição que cuida e espaço alternativo à ausência dos pais. O cuidado é mencionado para atender às necessidades básicas das crianças e desarticulado da sua dimensão educativa. 
O caráter normatizador da instituição também é revelado por possibilitar a transmissão de valores necessários ao futuro adulto. A visão preponderante refere-se ao reconhecimento da educação infantil como alicerce ${ }^{8}$ para uma escolaridade futura, destacando- se a preparação da criança para o ensino fundamental. Essa concepção de educação infantil alia-se à ideia da criança enquanto um "vir a ser", um cidadão do amanhã.

A representação da educação infantil não corresponde ao que poderíamos elencar como uma educação emancipatória e compromete a identidade das creches enquanto espaço de cidadania da infância. As instituições de educação infantil têm um importante papel político na efetivação dos direitos das crianças. Sarmento (2001, p.25) destaca que, no contexto educacional, esses direitos podem ser definidos como:

[...] 1) o direito à realização pessoal (enhancement), isto é, o direito ao desenvolvimento pessoal, intelectual e material, e "à experimentação dos limites, através da qual se realiza a compreensão crítica do mundo e se descobrem novas possibilidades; 2) o direito à inclusão social, intelectual, e cultural, que permita a cada criança ser autônoma no interior da respectiva comunidade, sendo nela aceita e acolhida; 3) o direito à participação na prática e decisões coletivas.

Dentre as cinco educadoras entrevistadas apenas uma enfocou a educação infantil comprometida com o desenvolvimento integral da criança.

[...] eu não imaginava que o trabalho da creche fosse assim, puxar tanto da criança, trazer tantos conhecimentos, tanta novidade para ela. [...] eu acho que é crescimento, apren-

8. Os resultados apresentados no livro Consulta sobre qualidade da educação infantil (2006, p.56) demonstram que a categoria "alicerce para escolaridade futura" foi manifestada pelas profissionais entrevistadas ao responderem sobre as finalidades da educação infantil. 
dizado, é descoberta, eu acho que é isto a educação infantil. [...]. (Gardênia)

A representação da concepção de educação infantil das educadoras é, ainda, focada como um trabalho de estimulação para o qual deverá ser conduzido o desenvolvimento infantil, ou seja, temos aqui as influências da Psicologia do Desenvolvimento, que prevê um comportamento padronizado e homogeneizado das crianças. É preciso considerarmos que educar é muito complexo e integra várias dimensões do desenvolvimento humano como cognição, afetividade, saúde, emoção, expressão e cuidados.

Podemos constatar essa representação de educação infantil na fala das entrevistadas:

A educação de 0 a 3 anos ela é mais de estimulação. Porque você pode cantar com elas, mas igual certas coisas elas não falam ainda, mas elas entendem tudo, então você cantando, contando história, dançando, você estimula ela. (Angélica)

Eu acho que no início trabalhar o estímulo e depois até o desenvolvimento mesmo, porque como eu vejo aí, na minha sala a gente começou com as crianças que elas quase não falavam e dentro de 3 meses do nosso trabalho elas já estão falando.[...] o aspecto mais importante do trabalho eu acho que é a estimulação, além dos cuidados básicos diários, que a gente sabe que são necessários, a higiene e tudo mais, mas eu acho que na faixa etária que eu trabalho é o sentido da estimulação. (Dália)

Embora o lúdico tenha sido expressivo nos dados da pesquisa, elencado como direito das crianças por $26,4 \%$ das entrevistadas nos questionários, em entrevistas elas não apontaram a sua relevância para o desenvolvimento integral da criança. Dentre as teorias sobre o brincar, encontramos na teoria histórico-cultural uma fundamentação para que o brincar torne-se um dos eixos principais da proposta curricular das instituições de educação infantil, 
visto que é através das brincadeiras que a criança apreende a realidade cultural e desenvolve as suas potencialidades. Para que o brincar seja garantido como um direito é preciso que os espaços e tempos das instituições de educação infantil sejam cuidadosamente preparados e organizados, oportunizando às crianças brinquedos adequados às suas faixas etárias e que contribuam para enriquecer o processo de interação social. Sarmento (2004, p.25), ao discutir a importância do reconhecimento da criança como sujeito social, enfatiza a necessidade de se reconhecer a criança como produtora de cultura destacando o lugar da ludicidade nas culturas infantis.

O brincar, embora seja destacado como um dos direitos da criança, não ocupa um eixo central nas práticas institucionais:

Então, assim toda criança gosta de brincar. Então é sempre importante ter todo dia assim o momento deles estar brincando. Igual, assim, quando a gente não prepara uma atividade eles sabem que é a brincadeira. Então outro dia que a gente vem com uma atividade, às vezes, eles não querem. Bom, eu acho assim que seria melhor a atividade porque eles estariam tendo o conhecimento mais amplo, mas agora assim eu acho que o brincar é fundamental para uma criança. [...] por isso que a gente sempre tem o objetivo de deixar eles brincarem pelo menos uma meia hora todos os dias. (Rosa)

O brincar é muito importante também. O brincar faz parte da rotina também. Porque é onde a criança mais desenvolve a imaginação, a criatividade, que é muito importante na criança, a interação com outras crianças, a criatividade. É por isso que deve ter a estimulação. Você deixa, elas soltam e não da estimulação e atenção elas brincam de qualquer jeito. Elas não sabem como começar. Então você mostra e aí já torna o brincar diferente. [...] Que em casa, esta criança fica livre para brincar. A criança não sabe brincar, a criança ao brincar você tem que estimular ela. (Angélica) 
As representações sobre o brincar, apresentadas por Rosa e Angélica, não garantem à criança o direito ao lúdico. $\mathrm{O}$ tempo para o brincar é um tempo reduzido, disciplinar e conduzido pelo adulto.

O brincar representa um meio real de aprendizagem, possibilitando que os adultos aprendam sobre as crianças e suas necessidades. Podemos conhecer aspectos importantes do desenvolvimento de uma criança através da maneira como ela brinca.

Segundo Oliveira (2002, p.15), a importância do brincar e do brinquedo pode ser justificada na educação infantil pelos seguintes motivos:

- é condição de todo o processo evolutivo neuropsicológico saudável;

- manifesta a forma como a criança está organizando sua realidade e lidando com suas possibilidades, limitações e conflitos, já que, muitas vezes, ela não sabe, ou não pode, falar a respeito deles;

- introduz a criança de forma gradativa, prazerosa e eficiente ao universo sócio-histórico-cultural;

- abre caminho e embasa o processo de ensino/aprendizagem favorecendo a construção da reflexão da autonomia e da criatividade.

O brincar apresenta três grandes núcleos organizadores: o corpo, o símbolo e a regra.

A criança brinca desde os primeiros meses de vida manifestando reações espontâneas e prazerosas diante de determinados estímulos, como ao som de um brinquedo. Posteriormente, a criança começa a brincar com o próprio corpo, o que favorecerá a construção de sua inteligência, afirmação pessoal e integração social. A partir dos dois anos, começa a utilizar ferramentas simbólicas com o uso da linguagem e da atividade mental, expressando como vê a realidade ou imagina como ela poderia ser. Através das brincadeiras, as crianças aprendem regras de convivência e diversos sentimentos. 
Segundo Vygotsky (1988, p.117), no brincar a criança está acima de sua idade média, acima de seu comportamento diário. Assim, na brincadeira de faz de conta, as crianças manifestam certas habilidades que não seriam esperadas para sua idade. Nesse sentido, a aprendizagem cria a zona de desenvolvimento proximal.

Nas instituições de educação infantil, torna-se fundamental a discussão do tempo e do espaço das brincadeiras, visto que o brincar tem sido cada vez mais reduzido no contexto institucional. Os jogos e as brincadeiras devem ser introduzidos na rotina institucional como estratégias fundamentais no processo de aprendizagem das crianças pequenas e não meramente como atividades para "ocupar" um determinado espaço de suas rotinas. 



\section{4 \\ EDUCAÇÃO INFANTIL: \\ NA TRILHA DO DIREITO}

Se as coisas são inatingíveis... ora!

Não é motivo para não querê-las... Que tristes os caminhos, se não fora a presença distante das estrelas! Mário Quintana, 1962

\section{Políticas para a infância e a trajetória da educação infantil no Brasil}

A origem das instituições de atendimento à infância, na Europa, do início até a metade do século XIX, foi marcada por distintas ideias de infância, modelos de organização dos lugares e opiniões sobre o que fazer com as crianças enquanto permanecessem nessas instituições. O desenvolvimento dessas instituições esteve atrelado ao desenvolvimento da vida urbana e industrial e ao agravamento das condições de vida de um contingente de pessoas, dentre elas mulheres e crianças. Assim, podemos afirmar que a história das instituições de educação infantil não pode ser compreendida ausente da história da sociedade e da família. 
Como destaca Kuhlmann Júnior (2001, p.81):

[...] a história das instituições pré-escolares não é uma sucessão de fatos que se somam mas a interação de tempos, influências e temas, em que o período de elaboração da proposta educacional assistencialista se integra aos outros tempos da história dos homens.

Segundo Bujes (2001, p.14), o surgimento das instituições de educação infantil relaciona-se com o surgimento da escola e do pensamento moderno entre os séculos XVI e XVII. Responde, também, às novas exigências educativas resultantes das relações produtivas advindas da sociedade industrial. O contexto histórico do surgimento dessas instituições é ainda marcado por mudanças no interior da organização familiar, que assume o modelo nuclear, e ao desenvolvimento de teorias voltadas para a compreensão da natureza da criança marcada pela inocência e pela inclinação às más condutas.

[...] o que se pode perceber é que existiram para justificar o surgimento das escolas infantis uma série de ideias sobre o que constituía uma natureza infantil, que, de certa forma, traçava o destino social das crianças (o que elas viriam a se tornar) e justificar a intervenção dos governos e da filantropia para transformar as crianças (especialmente as do meio pobre) em sujeitos úteis, numa sociedade desejada, que era definida por poucos. De qualquer modo, no surgimento das creches e pré-escolas conviveram argumentos que davam importância a uma visão mais otimista da infância e de suas possibilidades, com outros objetivos do tipo corretivo, disciplinar, que viam principalmente nas crianças uma ameaça ao progresso e à ordem social. (Bujes, 2001, p.15)

Para Kuhlmann Júnior (2000, p.8), as instituições de educação infantil, propagadas a partir das influências dos países europeus centrais, na transição do século XIX ao século XX, configuraram 
um conjunto de instituições modelares de uma sociedade civilizada. O autor (2001, p.81) também afirma que as instituições de educação infantil surgiram da articulação de interesses jurídicos, empresariais, políticos, médicos, pedagógicos e religiosos, o que determinou três distintas influências na história das instituições infantis, ou seja, a jurídico-policial, a médico-higienista e a religiosa.

Uma das primeiras instituições surgidas na Europa foi a escola de tricotar ou escola de principiantes, criada na França, em Oberlin, no ano de 1769, e tinha como objetivos a formação de hábitos morais e religiosos, bem como o conhecimento das letras e a pronúncia das sílabas. Na França, foram também criadas as salas de asilo, ${ }^{1}$ em 1826, cujos propósitos de atendimento versavam sobre o provimento de cuidados e educação moral e intelectual às crianças de 3 a 6 anos de idade, ao passo que as creches surgiram para atender as crianças até 3 anos. ${ }^{2}$ Kuhlmann Júnior (2001, p.73) afirma o caráter educacional da instituição, que, com objetivos próximos aos da escola maternal, deveria promover o desenvolvimento das crianças e, sobretudo, torná-las dóceis e adaptadas à sociedade. Assim, desde o seu início, é revelado o caráter ideológico do projeto educacional dessas instituições pautadas em um projeto de educação para a submissão.

Bujes também destaca o caráter ideológico das instituições de educação infantil:

[...] o que se pode notar, do que foi dito até aqui, é que as creches e pré-escolas surgiram a partir de mudanças econômicas, políticas e sociais que ocorreram na sociedade: pela incorporação das mulheres à força de trabalho assalariado, na organização das fa-

1. Segundo Oliveira (2005, p.61), era comum nas salas de asilo o agrupamento de até cem crianças comandadas por um adulto por meio de um apito.

2. Didonet (2001, p.12) afirma que os nomes atribuídos às creches, em diferentes países, expressam o caráter de guarda e proteção dessas instituições: garderie, na França, asili, na Itália, écoles gardiennes, na Bélgica, e guardería em vários países latino-americanos. 
mílias, num novo papel da mulher, numa nova relação entre os sexos, para citar apenas as mais evidentes. Mas, também, por razões que se identificam com um conjunto de ideias novas sobre a infância, sobre o papel da criança na sociedade e de como torná-la, através da educação, um indivíduo produtivo e ajustado às exigências desse conjunto social. (Bujes, 2001, p.15)

O jardim de infância foi criado em 1840 na Alemanha por Froebel, para o atendimento das crianças de 3 a 7 anos, e contrapõe-se às demais instituições por ser detentor exclusivo de uma proposta pedagógica que visava à educação integral da infância e defendia um currículo centrado na criança. O jogo e as atividades de cooperação delinearam os objetivos das propostas pedagógicas. Apesar de sofrer represálias do regime reacionário prussiano, essa instituição propagou-se intensamente pela Europa a partir de 1870.

[...] o regime reacionário prussiano, que suprimiu a revolução liberal de 1848, proibiu os kindergartens em 1851, considerados centros de subversão política e de ateísmo - por sua visão não ortodoxa da religião - bem como por facilitar e estimular o trabalho da mulher fora do lar e pela ideia de levar as características femininas para a esfera pública. (Kulhmann Júnior, 2001, p.11)

Em relação à criação dos jardins de infância no Brasil, Kuhlmann Júnior (2001, p.84) esclarece que as primeiras iniciativas foram do setor privado para o atendimento às crianças da elite. No Rio de Janeiro foi fundado em 1875 o jardim de infância do Colégio Menezes Vieira, e em São Paulo, em 1877, o da Escola Americana. No ano de 1896 foi criado, pelo setor público, o jardim de infância Caetano de Campos para o atendimento às crianças da burguesia paulistana.

A difusão das instituições de educação infantil, propagadas pelos modelos europeus e norte-americano, em especial creches e jardins de infância, acompanham outras iniciativas de regulação da vida social moderna, como a industrialização, urbanização, desen- 
volvimento científico e tecnológico. Nos congressos científicos eram enfatizadas como importantes instituições a respaldarem os ideários de modernidade e progresso aspirados pelos países em desenvolvimento. Kuhlmann Júnior (2001, p.78) concluiu, com base nas análises das exposições internacionais entre 1850-1920, que creches, salas de asilo, escolas maternais e jardins de infância sempre foram incluídas como instituições de educação infantil, porém o que as diferenciava eram a origem e a faixa etária do público social a que se destinavam.

\section{As ações e os programas das instituições de educação infantil no início do século $X X$}

Segundo Kramer, as políticas públicas para a infância brasileira, do século XIX até as primeiras décadas do século XX são marcadas por ações e programas de cunho médico-sanitário, alimentar e assistencial, predominando uma concepção psicológica e patológica de criança, inexistindo um compromisso com o desenvolvimento infantil e com os direitos fundamentais da infância:

[...] voltadas, quando muito, para a liberação das mulheres para o mercado de trabalho ou direcionar a uma suposta melhoria do rendimento escolar posterior, essas ações partem também de uma concepção de infância que desconsiderava a sua cidadania e desprezava os direitos sociais fundamentais capazes de proporcionarem às crianças brasileiras condições mais dignas de vida. (Kramer, 1988, p.199)

Até meados da década de 20 do século passado, a assistência à infância foi realizada basicamente por entidades particulares. Kramer (2003a, p.48) também destaca que o atendimento à

3. A autora, ao traçar o quadro de atendimento à criança em idade pré-escolar, estabelece duas fases distintas de análise: a primeira datada do descobrimento do país até os anos 1930 e a segunda dos anos 1930 a 1980. Para a abordagem da primeira fase recorre aos estudos de Morcorvo Filho. 
criança era caracterizado pela ausência de proteção jurídica e alternativas de atendimento, bem como por programas no campo da higiene infantil, médica e escolar, com a predominância de entidades particulares e grupos médicos na coordenação dos trabalhos institucionais.

Alguns dos estudiosos da história da política da infância no Brasil (Kuhlmann Júnior, 2001; Kramer, 2003a; Oliveira, 2005) descrevem que as primeiras experiências de ações e programas destinados às crianças eram voltados à infância "desvalida". Oliveira (2005, p.92) ressalta que, no período precedente à República, as iniciativas isoladas de proteção à infância, realizadas através de entidades de amparo, orientavam-se para o combate das altas taxas de mortalidade infantil.

Para o atendimento à infância brasileira desvalida existiu, até 1874, a "Casa dos Expostos" ou "Roda", instituição destinada ao abrigo e acolhimento das crianças desamparadas. Constata-se que as primeiras iniciativas foram resultantes de ações higienistas centradas no combate à mortalidade infantil, cujas causas eram atribuídas aos nascimentos ilegítimos (consequentes da união entre escravos ou destes com seus senhores) e também à falta de conhecimentos intelectuais das famílias para o cuidado com as crianças.

Nas últimas décadas do século XIX e início do século XX, o Estado começou a ter uma presença mais direta na questão da infância, atuando, inicialmente, como agente fiscalizador e regulamentador dos serviços prestados pelas entidades filantrópicas e assistenciais.

Em 1899 foi criado no Rio de Janeiro o Instituto de Proteção e Assistência à Infância do Brasil. Conforme Kramer (2003a, p.52), o Instituto tinha como objetivos:

Atender os menores de oito anos, elaborar leis que regulassem a vida e saúde dos recém-nascidos, regulamentar o serviço das amas de leite, velar pelos menores trabalhadores e criminosos; atender as crianças pobres, doentes, defeituosas, maltratadas e 
moralmente abandonadas; criar maternidades, creches e jardins de infância.

O Instituto foi o precursor da assistência científica no país, que tinha como objetivo aliar a ciência à ideologia capitalista.

Kuhlmann Júnior revela outras características da assistência científica, ${ }^{4}$ como os baixos recursos destinados ao atendimento aos pobres, a concepção da educação assistencialista que, fundamentada na pedagogia da submissão, deveria disciplinar os pobres, preparando-os para a aceitação da exploração social e a ausência do Estado na gestão dos programas.

A esse respeito, o autor esclarece:

A concepção da assistência científica, formulada no início do século XX, em consonância com as propostas das instituições de educação popular difundidas nos congressos e nas exposições internacionais, já previa que o atendimento da pobreza não deveria ser feito com grandes investimentos. A educação assistencialista promovia uma pedagogia da submissão, que pretendia preparar os pobres para aceitar a exploração social. O Estado não deveria gerir diretamente as instituições, repassando recursos para as entidades. (Kuhlmann Júnior, 2000, p.8)

Dessa forma, a assistência científica era compreendida como "o lugar onde se pensava cientificamente a política social para os mais pobres, em que se suprimiam os direitos para se garantir a desobrigação de oferecer os serviços" (Kulhmann Júnior, 2001, p.53).

4. Kuhlmann Júnior (2001, p.64-8) enfoca três aspectos da assistência científica. O primeiro referente ao conjunto de medidas não caracterizado pelo direito, mas pela subserviência dos que dela necessitassem, cumprindo a sua função preconceituosa e disciplinar sobre os pobres trabalhadores. O segundo aspecto remete à polarização entre o papel do Estado e da sociedade civil nas ações de atendimento, e o terceiro é a adoção de um método científico para sistematizar as ações e os conhecimentos no intuito de controle social e moralização da pobreza. 
Paralelamente à fundação do Instituto, em 1899, ocorreram as primeiras tentativas para a criação das $\operatorname{creches}^{5}$ e dos jardins de infância.

A origem das creches no Brasil revela antecedentes do atendimento das instituições asilares, ${ }^{6}$ apresentando um atendimento, até os anos 1920, de caráter eminentemente filantrópico, destinado especialmente às mães solteiras e viúvas que não apresentavam condições para cuidar de seus filhos. A origem da instituição está atrelada ao desenvolvimento do capitalismo, da industrialização e da inserção da mulher no mercado de trabalho.

A esse respeito, Didonet (2001, p.12) esclarece:

As referências históricas da creche são unânimes em afirmar que ela foi criada para cuidar das crianças pequenas, cujas mães saíam para o trabalho. Está, portanto, historicamente vinculada ao trabalho extradomiciliar da mulher. Sua origem, na sociedade ocidental, está no trinômio mulher-trabalho-criança. Até hoje a conexão desses três elementos determina grande parte da demanda.

Segundo Merisse (1997, p.31), a história das creches no Brasil deve ser compreendida no contexto da história das políticas públicas para a infância, tendo implicações diretas para os períodos históricos que marcaram a realidade brasileira e a relação entre a organização do Estado e da sociedade.

5. Ao contrário da Europa, no Brasil, as creches sucederam as demais instituições de educação infantil, como os asilos, escolas maternais e jardins de infância. As primeiras instituições foram criadas no período da República, chegando ao número de 15 instituições em 1921, e 41 no ano de 1924, distribuídas em várias capitais e cidades do país.

6. Os asilos foram instalados no Brasil a partir do século XVIII, e tinham como clientela as crianças nascidas de relacionamentos ilegítimos entre senhores e escravas ou os legítimos das escravas que eram retirados da mãe para que esta pudesse ser alugada como mãe de leite. 
As primeiras creches, em algumas cidades do país, vieram substituir a Casa dos Expostos, ${ }^{7}$ instituições criadas para receber e cuidar das crianças abandonadas, atendidas em regime de internato. Podemos observar que as creches no Brasil surgiram para minimizar os problemas sociais decorrentes do estado de miséria de mulheres e crianças, ao contrário dos países da Europa, em que a expansão das creches decorria da necessidade do atendimento às crianças cujas mães foram recrutadas como mão de obra para as fábricas.

As primeiras experiências do atendimento em creches no início do século XX revelaram seu caráter assistencial e custodial, voltado ao atendimento das crianças e famílias empobrecidas. Apresentavam elementos que marcaram por longos anos a história da instituição na sociedade, como o seu caráter beneficente, a especificidade da faixa etária, a qualidade das mães como pobres e trabalhadoras, conforme apresentado no relato do jornal A mãi de família, escrito pelo dr. K. Vinelli (1879 apud Civiletti, 1991, p.36), médico da Casa dos Expostos.

[...] A creche é um estabelecimento de beneficência que tem por fim receber todos os dias úteis e durante horas de trabalho, as crianças de dois anos de idade para baixo, cujas mães são pobres, de boa conduta e trabalham fora de seu domicílio.

A implantação da primeira creche no país ocorre no ano de 1889, no Rio de Janeiro, junto à fábrica de Fiação e Tecidos Corcovado. No ano de 1918 foi criada a primeira creche no Estado de São Paulo, resultante das pressões dos movimentos operários, em uma vila operária da Companhia Nacional de Tecidos e Jutas.

7. Casa dos Expostos eram instituições criadas para o atendimento de crianças abandonadas. Segundo Civiletti (1991), o nome de roda, pelo qual se tornaram mais conhecidas, deve-se à assimilação da instituição ao dispositivo onde eram depositadas as crianças. Em São Paulo, a Roda de Expostos ocorreu em 1825, com a chegada do Sistema Assistencial da Misericórdia. 
Na década de 1920, alguns indicadores contribuíram para que as creches se tornassem pauta de reivindicações na sociedade, como o crescimento da industrialização no país, a formação de uma nova elite burguesa (em substituição à elite cafeeira), o agravamento do estado de miséria de um grande número de pessoas, a inserção da mulher nas fábricas, o operariado migrante europeu e o início das tensões nas relações patrões-operariado.

Segundo Oliveira (1988, p.46), as iniciativas de creches para atendimento à classe operária visavam atenuar os conflitos eminentes das relações de capital, nas quais a prática patronal oscilava entre o exercício da repressão e a concessão de benefícios sociais. Para alguns patrões, havia o reconhecimento das vantagens da instituição no aumento da produção da mãe trabalhadora.

A concessão patronal das creches tinha um caráter de favor e não de dever social, em resposta às reivindicações da classe operária por melhores condições de vida. A expansão do atendimento em creches, ainda que insignificante nesse período, estava relacionado ao "poder" da organização popular na reivindicação dos direitos sociais, o que terá uma dimensão maior na década de 1980. O aumento do atendimento em creches responde, de certa forma, ao reconhecimento das autoridades governamentais da presença feminina no trabalho industrial, o que obrigou os proprietários das indústrias a reconhecer o direito de amamentar de suas funcionárias.

Segundo Oliveira (2005, p.97), em 1923 houve a primeira regulamentação sobre o trabalho da mulher, prevendo a instalação de creches e salas de amamentação próximas aos locais de trabalho.

Nesse período, seja nos locais de moradia ou nos locais de trabalho, as creches apresentavam uma função de guarda das crianças, tendo como referência um modelo hospitalar, geralmente sob os cuidados de profissionais da área da saúde.

A presença da concepção médico-higienista nas creches, segundo Kuhlmann Júnior, encobre a difusão da ideia de sociedade moderna e civilizada e a ideologia do progresso. O autor analisa, 
ainda, a relação do saber aliado ao capital no cultivo da ideologia do progresso, pois a filantropia deveria manter um controle sobre a reprodução da classe trabalhadora e de suas vidas sob o enfoque da "assistência científica".

No final do século XIX e início do século XX, [...] criaram-se leis e propagaram-se instituições sociais nas áreas da saúde pública, do direito da família, das relações de trabalho, da educação. [...] são iniciativas que expressam uma concepção assistencial a que denominamos "assistência científica" por se sustentar na fé, no progresso e na ciência característica daquela época. (Kuhlmann Júnior, 2001, p.60)

$\mathrm{O}$ atendimento nas creches, vinculado à esfera médica e sanitarista, objetivava nutrir as crianças, promover a saúde e difundir normas rígidas de higiene, associando à pobreza a falta de conhecimentos de puericultura e abafando qualquer relação com as questões econômicas e políticas do país.

Em 1925 foi promulgado um decreto no Estado de São Paulo regulamentando as escolas maternais, e em 1935 foram instituídos os parques infantis nos bairros operários, sob a direção de Mário de Andrade. Os parques infantis atendiam crianças de diferentes idades em horário contrário ao da escola para atividades recreativas.

As políticas públicas, no início da década de 1930, foram resultantes de interesses distintos da burguesia, dos trabalhadores e do Estado, fazendo com que o poder público fosse chamado cada vez mais a regulamentar a questão do atendimento à infância. $\mathrm{Na}$ esfera federal, a partir de 1930, o Estado, com a criação do Ministério da Educação e Saúde, assumiu oficialmente responsabilidade pelo atendimento à infância, embora continuasse a convocar a contribuição das instituições particulares.

Dessa forma, em São Paulo, até 1930, mantiveram-se instituições com objetivos diferenciados no atendimento das crianças de 0 a 6 anos, de cunho assistencial ou educativo e pedagógico. 
Kuhlmann Júnior (2001, p.182) considera que o assistencialismo nas creches consistia na pedagogia e na educação oferecidas às crianças empobrecidas:

A pedagogia das instituições educacionais para os pobres é uma pedagogia da submissão, uma educação assistencialista marcada pela arrogância que humilha para depois oferecer o atendimento como dádiva, como favor aos poucos selecionados para receber.

Ao caracterizar as décadas de 1930 e 1940 como "fase da assistência social" no atendimento à infância no Brasil, Geis (1994) reafirma o paternalismo do Estado, propagado por programas que priorizavam a alimentação e a higiene das mulheres trabalhadoras e de seus filhos. Tais programas marcaram a participação financeira dos empresários nas iniciativas de atendimento à infância, por objetivarem, sobretudo, a reprodução da classe trabalhadora.

A fase da assistência social marcou o paternalismo do Estado, preocupado com a sobrevivência das crianças da classe trabalhadora, enquanto mão de obra futura, para o que convocou a participação financeira do empresariado nas obras de atendimento infantil. (Geis, 1994, p.86)

Na década de 1940, ainda regida pelo regime ditatorial do governo de Getúlio Vargas, fundamentado na ideologia desenvolvimentista, ocorreu um marco legal na legislação sobre as creches com CLT, que apresentava a obrigatoriedade de as empresas particulares com mais de 30 mulheres empregadas acima de 16 anos manterem creches para os filhos de suas empregadas. Essa lei referiu-se apenas ao período de amamentação, afirmando que "caberia às empresas oferecer local apropriado onde seja permitido às empregadas guardar sob vigilância e assistência os seus filhos no período de amamentação" (artigo 389, § 1ํ, 1943). A obrigatoriedade da empresa em manter creches poderia ser subs- 
tituída por convênios com creches distritais, segundo a mesma lei. A ausência de fiscalização do poder público possibilitou o não cumprimento da CLT pela maioria dos empresários, o que se mantém até os dias atuais. Cabe ressaltar a presença da concepção assistencialista nessa iniciativa, visto que a creche era concebida como um benefício trabalhista para a mulher trabalhadora e não como um direito do trabalhador em geral, ou mesmo da criança.

Podemos observar que na década de 1940 prosperaram iniciativas governamentais na área de saúde, previdência e assistência. $\mathrm{O}$ higienismo, a filantropia e a puericultura embasavam as práticas das instituições de atendimento às crianças, permeadas por rotinas rígidas de saúde e higiene.

O higienismo constitui-se como um movimento formado por médicos de orientação positivista, surgido no século XIX na Europa, em resposta aos altos índices de mortalidade infantil. Segundo Merisse (1997, p.33), no concernente à família, o higienismo alterou tanto o perfil sanitário como sua feição social, influenciando decisivamente no papel materno da mulher, que envolvia a amamentação, o cuidado e a educação das crianças pequenas. Assim, a família, como outras instituições de atendimento às crianças, como as creches, passaram a incorporar a pedagogia higienista.

Nesse período foram criados o Departamento Nacional da Criança, ${ }^{8}$ em 1940, vinculado ao Ministério da Educação e Saúde Pública e, em 1941, o Serviço de Assistência a Menores, vinculado ao Ministério da Justiça e Negócio Interiores. Os projetos desenvolvidos por esses órgãos propunham um atendimento pautado na esfera médica e culpabilizavam as famílias pelas condições de vida, desconsiderando-se qualquer análise das condições advindas da situação econômica e social do país.

8. Segundo Merisse (1997, p.40), o Departamento Nacional da Criança foi o principal formulador da política oficial para a infância brasileira por quase trinta anos. Sua proposta de atendimento focava a medicina preventiva e a puericultura, reconhecendo a família como a grande responsável pela situação da criança. 
No ano de 1941, foi criada a Legião Brasileira de Assistência (LBA), ${ }^{9}$ com o objetivo de coordenar os serviços sociais do governo, sendo formuladora e executora da política governamental de assistência destinada à família e ao atendimento da maternidade e da infância.

As políticas voltadas para a infância no Estado Novo configuraram ações de tutela e proteção, havendo a regulamentação e criação de diversas instituições públicas voltadas às crianças de $0 \mathrm{a}$ 6 anos.

Nesse período, a criança é apresentada como cidadã do futuro, devendo receber cuidados especiais do Estado com o objetivo implícito de fortalecimento do estado ditatorial de Vargas.

Kramer revela que nos discursos de Getúlio Vargas e de seus seguidores estava presente a visão da criança como cidadã do futuro, estando as ações de proteção, amparo e salvação da infância configuradas como uma "missão nacional", objetivando, sobretudo, o fortalecimento do Estado autoritário.

Crianças brasileiras nascidas na abastança ou na pobreza, escoteira ou desvalida, sois vós o futuro da Pátria, porque a criança, num conceito escoteiro, é o ser que continuará a tarefa por nós iniciada [...]. Todo nosso anseio de perfeição será para ela, e o destino da Pátria e da Humanidade dela dependerá. (Lima, 1943 apud Kramer, 1988, p.200)

Segundo Rosemberg (2002a, p.36), os programas de assistência, dentre eles os programas de educação infantil propagados no período da ditadura militar sob a orientação da Doutrina de Segurança Nacional, buscavam responder aos ideários da guerra fria, visando ao combate à pobreza enquanto estratégia de enfrentamento dos ideários comunistas.

9. A LBA, em seu início de atendimento, tem uma atuação mais focada nas famílias dos convocados da guerra, e, com o fim da mesma, passa a exercer a função de formuladora e executora da política de assistência destinada à família e ao atendimento da maternidade e da infância. 
Com o fim do Estado Novo, o paternalismo ainda se manteve como caráter eminente nas ações à infância, porém "fortalecido pela ideologia do desenvolvimento de comunidades e da assistência social difundidos na década de 50" (Kramer, 1988, p.202).

O regime autoritário instaurado com o golpe militar de $1964^{10} \mathrm{e}$ o agravamento das condições de vida da maioria da população brasileira ocasionaram ações paliativas e reguladoras da explosão social, acarretando profundas mudanças na ação governamental destinada à infância e à adolescência no país. Destacam-se ações e programas desarticuladores, marcados pelo clientelismo político e pela repressão. O governo apresenta uma Política Nacional de Bem-Estar do Menor, criando a Fundação Nacional de Bem-Estar do Menor (Funabem) e as Fundações Estaduais de Bem-Estar do Menor (Febem), visando atender os menores "abandonados", "infratores", de "conduta antissocial" e em "situação de risco".

Os impactos do sistema econômico e político do Brasil, na década de 1960, terão uma atuação na política de atendimento às crianças. As creches, em especial, serão reivindicadas em consonância às necessidades da classe trabalhadora, no patamar de equipamento social necessário diante das questões sociais emergidas com o agravamento das condições de vida da população e a crescente demanda por serviço de consumo coletivo, como transporte, saúde, escolas, creches e outros.

As características do sistema econômico adotado no Brasil, de capitalismo dependente e concentrador de riquezas, continuou impedindo que a maioria da população tivesse satisfatórias condições de vida. O baixo salário e a falta de extensão de serviços de infraestrutura urbana para atender as necessidades sociais agravam a questão da creche que nessa altura não é mais aceita apenas como uma ajuda filantrópica ou empresarial, mas co-

10. A década de 1960 no Brasil marca um momento de crise política em consonância com o contexto da guerra fria, que culminará com o golpe militar de 1964. 
meça a ser reivindicada pela população mais pobre como necessidade de mães que precisam trabalhar para a subsistência da família. (Oliveira, 1988, p.48)

Em 1966, ocorre o I Seminário sobre Creches no Estado de São Paulo, promovido pela Secretaria do Bem-Estar Social, em que o conceito de creche defendido é: "um serviço que oferece um potencial capaz de garantir o desenvolvimento infantil, compensando as deficiências de um meio precário próprio das famílias de classe trabalhadora" (Haddad \& Oliveira, 1990, p.109).

A creche é apresentada como instituição de atenção à infância capaz de atender os filhos da mãe que trabalha, contribuindo na promoção da família e na prevenção da marginalidade. É ressaltado o modelo substituto-materno no atendimento, influenciado pelos pressupostos teóricos da privação materna de John Bowlby.

Há forte preocupação em sensibilizar a sociedade civil para a qualidade do atendimento oferecido às crianças, especialmente acerca da necessidade de profissionais especializados na área do desenvolvimento e educação infantil. Ocorre a inserção de profissionais das áreas do Serviço Social, da Psicologia, da Pedagogia e outras áreas afins, os quais, influenciados pelo tecnicismo, especialmente os profissionais do Serviço Social, passam a esboçar uma ação técnica a seu trabalho, especialmente com as famílias, de cunho educativo e normativo.

As discussões sobre a função social da creche e o seu reconhecimento como instituição destinada à educação das crianças serão intensificadas, a partir dos anos 1970, concomitantemente às mudanças no quadro das políticas para a infância no país.

\section{Os desafios da educação infantil no Brasil, a partir das últimas décadas do século $\mathrm{XX}$}

Rosemberg (2002a, p.25; 2002b, p.33) concebe a educação infantil integrada às políticas sociais como um subsetor das políticas 
educacionais e de assistência ao(à) trabalhador(a), considerando os anos 1970 um marco para o estudo da educação infantil no país, visto ser nesse período que a educação infantil entrou na pauta do movimento social por meio da "luta por creches". A autora apresenta três grandes períodos que marcaram a história da educação infantil no Brasil nas últimas décadas do século XX. O primeiro período, datado do fim dos anos 1970 e início dos 1980, foi caracterizado pela influência do Unicef e da Unesco na educação infantil brasileira, organismos estes que difundiram nos países subdesenvolvidos a ideia de uma "educação pré-escolar compensatória de carências de populações pobres e apoiadas em recursos da comunidade visando despender poucas verbas do Estado para sua expansão" (Rosemberg, 2002b, p.33). Os modelos de educação infantil de massa, divulgados por esses organismos, contribuíram para a criação de programas e projetos de educação infantil no Brasil destinados especialmente aos mais carentes e às regiões mais empobrecidas, como a região Nordeste. Segundo Rosemberg, foram criados nesse período dois grandes programas de âmbito federal: o Programa Casulo, administrado pela Legião Brasileira de Assistência (LBA) e o Programa Nacional de Educação Pré-Escolar, implantado pelo Ministério da Educação. Para a autora, os efeitos dos modelos de educação infantil de massa "retardaram o processo de construção nacional de um modelo de educação infantil democrático, de qualidade, centrado na criança, isto é, em suas necessidades e cultura" (Rosemberg, 2002a, p.39).

Recorrendo a documentações da Unesco e do Unicef, a autora sistematiza as propostas desses organismos para a educação infantil dos países subdesenvolvidos:

- A expansão da EI constitui uma via para combater a pobreza (especialmente desnutrição) no mundo subdesenvolvido e melhorar o desempenho do ensino fundamental, portanto sua cobertura deve crescer; 
- Os países pobres não dispõem de recursos públicos para expandir, simultaneamente, o ensino fundamental (prioridade número um) e a EI;

- A forma de expandir a EI nos países subdesenvolvidos é por meio de modelos que minimizem investimentos públicos, dada a prioridade de universalização do ensino fundamental;

- Para reduzir os investimentos públicos, os programas devem se apoiar nos recursos da comunidade, criando programas denominados "não formais", "alternativos", "não institucionais”, isto é, espaços, materiais, equipamentos e recursos humanos disponíveis na "comunidade", mesmo quando não tenham sido concebidos ou preparados para essa faixa etária e por seus objetivos. (Rosemberg, 2002a, p.34)

Como herança desse primeiro período, Rosemberg (2002b, p.33) cita a criação da Coordenação de Educação Infantil (Coedi), vinculada à Secretaria do Ensino Fundamental, órgão do Ministério da Educação, a expansão de modelos "não formais" de educação infantil marcados pela improvisação quanto ao espaço físico, material pedagógico e mão de obra; a criação das creches comunitárias e municipais; a presença de profissionais leigos nas instituições e a presença de crianças com mais de 7 anos na educação infantil, com a consolidação de três modalidades de atendimento: creches, pré-escolas e classes de alfabetização.

Nesse período, os discursos e práticas no atendimento às crianças nas creches são influenciados pelas teorias da privação cultural e da educação compensatória, atribuindo à instituição o papel de suprir as carências de ordem física, material, social e psicológica das camadas empobrecidas: "além de ocupar o lugar da falta moral, econômica e higiênica da família, a creche também terá que dar conta da carência afetiva, social, nutricional e cognitiva da criança" (Haddad, 1991, p.114).

O segundo período, iniciado após a ditadura militar, acontece no contexto de eclosão dos movimentos sociais no país e de intensa mobilização política em prol da abertura democrática. A década de 
1980 foi cenário de grande mobilização em torno dos direitos das crianças e dos adolescentes, com ampla participação da sociedade civil, resultando em um novo ordenamento legal e em uma nova doutrina da infância, na qual a criança deixa de ser vista como objeto de tutela e passa a ser considerada sujeito de direitos, dentre eles a educação infantil. No âmbito do Ministério da Educação, a concepção de educação infantil é referenciada ao educar e ao cuidar, ocorrendo toda uma articulação para vinculação da educação infantil ao campo da educação, e não mais da assistência social.

Com a expansão dos movimentos sociais no país, nos anos 1980, houve uma significativa pressão popular pela ampliação das vagas em creches no Município de São Paulo. A instituição passou a ser reivindicada como direito da criança e da mulher trabalhadora. As reivindicações, as quais atribuíam ao Estado a responsabilidade pelo atendimento, inicialmente partiram das mulheres da periferia, em geral donas de casa e domésticas, organizadas através do clube de mães. Posteriormente, operárias, grupos feministas e intelectuais aderiram ao movimento.

No ano de 1979, na realização do I Congresso da Mulher Paulista, of icializou-se o Movimento de Luta por Creches. ${ }^{11}$

A creche passou a ser reivindicada, também, pela população de classe média, que, somada à necessidade de trabalho feminino, apresentava o reconhecimento do caráter educativo da instituição de atendimento às crianças. Inicia-se, nesse momento, um período de mudança da identidade institucional, ampliando o seu caráter assistencialista à dimensão educacional.

A organização popular pela reivindicação das creches é incorporada aos demais movimentos em defesa da criança e do adoles-

11. O Movimento de Luta por Creches, assim como os demais movimentos populares urbanos, foi gerado a partir de mudanças estruturais e conjunturais com a incorporação da mão de obra feminina das diferentes classes sociais no mercado de trabalho, possibilitando às mulheres uma tomada de consciência do estado de opressão, e fornecendo às mesmas condições objetivas de organização e luta por seus direitos. 
cente, havendo, em 1988, o reconhecimento legal da instituição como direito da criança à educação, com a promulgação da Constituição brasileira. A questão da creche é legitimada como extensão do direito universal à educação das crianças de 0 a 6 anos, espaço de educação infantil, complementar à educação familiar.

O terceiro período da história da educação infantil no Brasil, segundo Rosemberg (2002a, p.41; 2002b, p.35), instala-se no conjunto de transformações societárias resultantes dos impactos da globalização e das políticas neoliberais, a exemplo da fragmentação da concepção hegemônica do Estado e das políticas sociais, e culmina com a aprovação da LDB, a qual incorpora as creches e pré-escolas como instituições de educação infantil, como vimos no capítulo anterior.

Conforme a LDB, a educação infantil tem como finalidade o desenvolvimento integral da criança até seis anos de idade, em seus aspectos físico, psicológico, intelectual e social, complementando a ação da família e da sociedade.

Segundo Oliveira (2005, p.49), para que as propostas pedagógicas de creches e pré-escolas atendam aos dispositivos legais, deverão:

[...] organizar condições para que as crianças interajam com adultos e outras crianças em situações variadas, construindo significações acerca do mundo e de si mesmas, enquanto desenvolvem formas mais complexas de sentir, pensar e solucionar problemas, em clima de autonomia e cooperação. Podem as crianças, assim, constituir-se como sujeitos únicos e históricos, membros de famílias que são igualmente singulares em uma sociedade concreta.

O reconhecimento do caráter educativo das creches implica o rompimento de sua herança assistencialista, assim como a definição de propostas pedagógicas para as crianças pequenas que possam garantir a aprendizagem e o desenvolvimento infantil respeitando as particularidades dessa faixa etária. 
O importante na efetivação dessa identidade institucional é que a creche seja um espaço de educação de qualidade, permitindo vivências e experiências educativas, comprometida com os direitos fundamentais da criança e garantindo a promoção da cidadania.

Considerando o quadro legal que legitima a educação infantil como direito das crianças de 0 a 6 anos e redimensiona o papel das creches e pré-escolas, muitos embates e desafios se fazem presentes, visto a historicidade da dicotomia existente entre o proclamado nas leis e o efetivado na realidade brasileira. Campos (2002, p.27) destaca outros fatores que intensificam a distância entre as leis e sua aplicabilidade, a saber: as diretrizes amplas e a ausência de previsão de mecanismos operacionais que garantam a aplicabilidade dos princípios legais. Assim, a transferência das creches do setor da assistência para o setor educacional não se deu de maneira efetiva quanto à definição de orçamentos específicos e à definição de políticas para a formação do quadro de pessoal.

Cabe ainda ressaltar os desdobramentos sobre a faixa etária a ser atendida. Historicamente, as creches destinaram-se ao atendimento integral das crianças de 0 a 6 anos, ao passo que a pré-escola ocupava-se das crianças a partir de 4 anos, em período parcial. A LDB, ao estabelecer o atendimento em creches às crianças de 0 a 3 anos, abre espaços para que as crianças acima de 4 anos tenham somente um atendimento em período parcial, o que se torna inviável para grande parte da população usuária desses serviços, considerando as condições de vida das crianças e do trabalho materno fora do lar. Atualmente, temos ainda a inclusão das crianças a partir de 6 anos no ensino fundamental. Esse fato tem suscitado muitas discussões e controvérsias, visto que os encaminhamentos da proposta não estão bem definidos do ponto de vista pedagógico.

Nesse cenário de embates e desafios das políticas públicas para a infância, é importante considerarmos que toda a legislação foi promulgada no momento histórico de retrocesso dos investimentos no setor social e educacional, em virtude das políticas neoliberais implantadas no país a partir da década de 1980. Como vimos na trajetória das políticas públicas para a infância, a atenção e os ser- 
viços destinados às crianças dependem da conjuntura política $e$ econômica e da correlação de forças existentes na sociedade.

Os estudos realizados sobre a temática da educação infantil no país (Rosemberg, 2002a e 2002b; Kramer, 2003b; e Haddad, 2006) têm destacado as influências dos organismos internacionais e das organizações multilaterais no atendimento à infância brasileira e a importância da articulação das políticas públicas de assistência, educação e saúde nos serviços institucionais.

Kramer (2003b, p.56) considera crucial a atenção às políticas para a infância, visto que a educação da criança pequena não é somente um direito social, mas direito humano.

[...] a educação da criança pequena é direito social porque significa uma das estratégias de ação (ao lado do direito à saúde e à assistência) no sentido de combater a desigualdade, e é direito humano porque representa uma contribuição, dentre outras, em contextos de violenta socialização urbana como os nossos, que se configura como essencial para que seja possível assegurar uma vida digna a todas as crianças.

Rosemberg (2002a, p.42) tem destacado as influências do Banco Mundial e das organizações multilaterais, a partir da década de 1990, no cenário das políticas educacionais brasileiras. No campo de educação infantil, o Banco Mundial apresenta uma nova concepção de "desenvolvimento infantil", fomentando iniciativas de programas focalizados para o combate à pobreza, através do incentivo de velhos modelos assistencialistas, como as creches filantrópicas e domiciliares.

Os programas, estudos e documentos oficiais publicados pelo Ministério da Educação e Cultura, os quais culminaram com a elaboração da Política Nacional de Educação Infantil (2006), foram norteados pelas metas estabelecidas na Conferência Internacional de Jomtiem, ocorrida em 1990, na Tailândia, a qual reuniu vários países e órgãos internacionais para a discussão da educação básica no mundo. O Brasil é signatário das diretrizes estabelecidas pela 
Conferência de Jomtiem, na qual o tema da primeira infância ganha destaque como primeira meta: "expandir e melhorar o cuidado e a educação da primeira infância, de modo integrado especialmente para as crianças vulneráveis e desfavorecidas" (Penn, 2002, p.9).

Segundo Penn (2002, p.13), as políticas de investimentos do Banco Mundial na educação infantil são subsidiadas pelo conceito de infância fundamentado na teoria do capital social. Conforme a autora, para o Banco Mundial, "o objetivo da infância é tornar-se um adulto plenamente produtivo, o 'capital humano' do futuro". Segundo essa perspectiva, a primeira infância é um momento privilegiado de investimentos, visto que o desenvolvimento cerebral ocorre com mais intensidade nesse período. A esse respeito, a autora assevera:

O Banco Mundial e outras agências doadoras supõem que as crianças pequenas passam pelos mesmos estágios de desenvolvimento nas mesmas idades, tanto em regiões remotas do Nepal como em Chicago. Para essa concepção, o que define a primeira infância é a capacidade cerebral. (Penn, 2002, p.15)

Como podemos perceber, estamos diante de novos paradigmas para discutirmos o destino da educação infantil no Brasil. Contudo, torna-se essencial considerarmos essa etapa da educação do ser humano com a devida seriedade, o que demanda a responsabilização do Estado e de toda a sociedade civil.

Segundo Haddad, a educação da criança pequena torna-se uma questão pública e, portanto, pertinente ao âmbito dos direitos humanos. No quadro dos novos paradigmas para a discussão das políticas para a educação infantil, a autora destaca ser necessário:

1. uma redefinição da relação entre público (Estado) e privado (família) nos assuntos relativos à infância;

2. o reconhecimento do direito da criança ser cuidada e socializada em um contexto social mais amplo que da família; 
3. o reconhecimento do direito da família de dividir com a sociedade o cuidado e a educação da criança;

4. o reconhecimento do cuidado infantil como uma tarefa profissional, que, juntamente com a educação num sentido mais amplo, constitui uma nova maneira de promover o desenvolvimento global da criança. (Haddad, 2006, p.532)

Considerando a trajetória das políticas públicas para a infância no Brasil, podemos identificar um processo de reconhecimento de uma nova identidade das creches enquanto instituições de educação infantil. As legislações sobre a infância brasileira ganham nova dimensão com a abertura democrática do país, em especial com o reconhecimento das creches como direito das crianças e das famílias e dever do Estado. Esse fato expressa a necessidade da garantia dos direitos da infância em instituições pautadas por critérios de qualidade que contemplem as funções do cuidar e do educar.

Apesar dos impasses para a efetivação das políticas públicas destinadas à infância, em especial pelas influências da política neoliberal e dos organismos internacionais nas políticas educacionais, o quadro legal a favor dos direitos da infância assegura a possibilidade de que a educação das crianças seja contemplada no âmbito dos direitos humanos. A discussão da proposta educativa nas creches requer um verdadeiro respeito aos direitos fundamentais das crianças e às necessidades e especificidades da primeira infância. A proposta de democratização da educação infantil deve romper com os estigmas históricos da creche, determinando uma educação de qualidade a todas as crianças e tornando a infância prioridade no quadro das políticas públicas brasileiras. 


\section{Representações sobre a educação infantil: discursos e práticas}

Como podemos observar, a trajetória das instituições de educação infantil revela que diferentes concepções sobre a infância e a educação infantil subsidiaram os discursos e as práticas das instituições destinadas ao atendimento das crianças pequenas.

Podemos traçar um quadro sobre as funções estabelecidas para a educação infantil tendo como referência o artigo de Abramovay \& Kramer (1991).

Inicialmente, as autoras referem-se à função guardiã da educação infantil, presente nas primeiras iniciativas das instituições de atenção à infância a partir do século XX na França e Inglaterra, respondendo aos reflexos das transformações societárias decorrentes do capitalismo. Essa primeira função traz embutida a concepção assistencialista, visto que tinha como objetivo o acolhimento das crianças pobres e abandonadas.

No século XIX, as instituições de educação infantil, em especial os jardins de infância de Froebel e as escolas de Montessori, nas favelas italianas, assumiram a função preparatória apresentando um atendimento subsidiado pelo discurso de compensar as deficiências das crianças, no tocante à sua pobreza e à incapacidade das famílias. Esse caráter será enfatizado no século XX, após a Segunda Guerra Mundial, nos Estados Unidos e Europa, determinado pelas influências das teorias de desenvolvimento infantil e da Psicanálise, como também pelos estudos linguísticos e antropológicos, os quais atribuíam à educação infantil a tarefa de combater o fracasso escolar, em especial das crianças populares, negras e filhas de imigrantes. No Brasil, essa concepção chega à década de 1970, apontada pelo discurso oficial como chave para os problemas educacionais, visto que deveria exercer uma função eminentemente preparatória para os ensinos posteriores. Segundo Abramovay \& Kramer (1991, p.32), a função preparatória da educação infantil, ao contrário de suprir carências, acabava por discriminar e marginalizar as crianças populares e suas famílias. 
A visão da educação infantil como objetivo em si mesma foi propagada nas propostas do MEC para a educação infantil na década de 1980. Nessa perspectiva, a função da educação infantil consiste em promover o desenvolvimento global e harmônico das crianças, porém as autoras revelam que essa concepção apresenta-se meramente como uma "nova roupagem" da função compensatória.

Ao contrário do enfrentamento dos males educacionais, seus objetivos estariam na cura dos males sociais, pois a "pré-escola não prepararia para a escolaridade posterior, mas ajudaria a superar problemas de cunho econômico-social" (Abramovay \& Kramer, 1991, p.33). Segundo as autoras, o fato de não mais ser reconhecida como preparatória para a escolaridade futura acarretava-lhe o significado de ser informal, não convencional e assistemática, contribuindo para a descaracterização do fator qualidade, imprescindível à proposta dita democrática na educação infantil, ou seja, a favor do desenvolvimento integral de todas as crianças, independente de classe social.

Diante do debate sobre as funções da educação infantil, é apontada uma nova função, ou seja, a função pedagógica. Esta proporcionaria o reconhecimento de que o campo prioritário das instituições de educação infantil é a educação da criança enquanto alternativa contrária à abordagem da privação cultural. Concordamos com Kramer (2003b, p.60) quando ela afirma que o pedagógico na educação infantil não pode ser compreendido como meramente a formação de hábitos e habilidades, a constituição de um projeto escolarizante, restrito à sala de aula e à transmissão de conteúdos do professor aos alunos. A autora destaca que o pedagógico tem como base a dimensão cultural, ou seja, é a possibilidade de experiência com o conhecimento científico e as diversas interfaces de acesso a este, como a literatura, a música, as artes, a história, etc.

A esse respeito, a autora esclarece: 
Se perdermos de vista a perspectiva cultural no seu sentido mais amplo, ou seja, no sentido de que as pessoas precisam se reconhecer na cultura, que são sujeitos da história e da cultura, além de serem por eles produzidos; se não percebermos essa perspectiva e reproduzirmos as crianças, as 21 milhões de crianças de zero a seis anos, a alunos, passamos a ter uma visão de que o pedagógico é algo instrucional e visa ensinar coisas. (Kramer, 2003b. p.63)

Dessa forma, podemos compreender que a dimensão pedagógica da educação infantil reconhece a criança como sujeito cultural, não mais um "vir a ser".

Conforme Martins Filho (2005, p.14), o reconhecimento da criança como ator social e cultural possibilita a construção de novos caminhos teóricos e metodológicos na educação infantil, capazes de romper com a visão abstrata ou romântica da infância, descontextualizada de sua inserção social. Isto implica uma proposta pedagógica centrada no desenvolvimento das potencialidades infantis, na valorização das manifestações das crianças e na gradativa conquista de novas aprendizagens.

E é ainda nessa dimensão pedagógica que podemos apresentar a função evocada nas últimas décadas, e também presente nos discursos das legislações da educação infantil, ou seja, a função de cuidar e educar, discutida no capítulo anterior.

Segundo Larrosa (1998 apud Martins Filho, 2005, p.14), é fundamental desconstruir e relativizar algumas certezas que tínhamos em relação à educação para pensarmos sobre o enigma que é a infância e reconhecermos as crianças como sujeitos ativos no processo educacional, com voz e expressões próprias. Martins Filho afirma a importância de as crianças serem sujeitos ativos nos espaços institucionais:

Por intermédio deste enfoque, é possível ver as crianças a partir de suas experiências e manifestações principalmente aquelas construídas por meio das relações estabelecidas com seus pares, 
e não mais como sujeitos passivos, ainda que elas sejam interdependentes dos adultos, ou de outros grupos sociais, como por exemplo, a família, os contextos instituições de educação e o Estado. (Martins Filho, 2005, p.14)

$\mathrm{O}$ autor informa que o debate acerca do reconhecimento da criança enquanto produtora de cultura decorre de estudos da Antropologia, em especial do trabalho primeiro de Charlotte Hardman, intitulado Can there be an Anthropology of Children, no qual afirma a necessidade de dar voz às crianças, por muito tempo silenciadas na história da humanidade por uma perspectiva adultocêntrica na educação infantil.

A produção cultural, por parte da criança, é concretizada no meio social e cultural no qual ela está inserida, construída nas dimensões relacionais da criança com a criança e da criança com o adulto. A criança é, pois, produto e produtor da cultura. Com isto, tomar a criança como produtora de cultura é "reconhecer suas expressões, nas mais variadas linguagens, como possibilidade de as crianças se introduzirem no mundo, oportunidade que as leve a viver as experiências socioculturais da infância" (Martins Filho, 2005, p.19).

O autor cita Faria (1999, p.48 apud Martins Filho, 2005, p.19) para especificar a condição da criança como produtora de cultura:

A criança não só depende e consome a cultura do seu tempo, como também produz cultura, seja à cultura infantil de sua classe, seja reconstruindo a cultura à qual tenha acesso. $\mathrm{O}$ fato da criança não falar, ou não escrever, ou não saber fazer as coisas que os adultos fazem transformam-na em produtora de uma cultura infantil, justamente através dessas especificidades.

Os espaços ou ambientes educativos das instituições da educação infantil constituem-se em cenários para a produção e reprodução das culturas infantis por serem espaços onde as crianças criam redes de socialização e interagem com seus pares e com os adultos. 
Oliveira também ressalta a importância de a criança interagir com parceiros diversos no contexto das instituições de educação infantil, explorar ambientes, aprender com o lúdico e, gradativamente, ampliar conhecimentos necessários para sua inserção no mundo. Destaca, ainda, alguns aspectos fundamentais para a construção das propostas pedagógicas das instituições de educação infantil, no que se refere aos aspectos estéticos, éticos e críticos:

A elaboração de uma proposta pedagógica para aquelas instituições requer valorizar, nas crianças, a construção da identidade pessoal e de sociabilidade, o que envolve o aprendizado de direitos e deveres. Na educação infantil, hoje, busca-se ampliar certos requisitos necessários para adequada inserção da criança no mundo atual: sensibilidade (estética e interpessoal), solidariedade (intelectual e comportamental) e senso crítico (autonomia, pensamento divergente). (Oliveira, 2005, p.49)

Retomando a história da educação infantil no país, vimos que o trabalho pedagógico nessas instituições, creches e pré-escolas, originam-se de programas higienistas e assistencialistas.

De acordo com Oliveira (2005, p.57), as práticas educativas e conceitos básicos a respeito da educação das crianças foram sendo historicamente construídos e determinando regulamentação e políticas públicas para a infância. Pode-se ainda perceber que muitas dessas práticas educativas e concepções ainda se fazem presentes no imaginário dos profissionais da educação infantil e no cotidiano de creches e pré-escolas.

Dessa forma, recorremos à história da educação infantil e de seus precursores, tendo como referências os estudos de Oliveira (2005), Rech (2005) e Kuhlmann Júnior (2000) para traçarmos a trajetória histórica dos discursos e práticas pedagógicas da educação infantil.

Segundo Oliveira (2005, p.59), nos séculos XV e XVI surgem novas visões sobre como educar as crianças. Autores como Erasmo (1465-1530) e Montaigne (1483-1553) defenderam a ideia de que a 
educação deveria respeitar a natureza infantil, estimular a atividade da criança e associar o jogo à aprendizagem. É nesse momento histórico, marcado por transformações econômicas, sociais, políticas e culturais na Europa, que se iniciaram os primeiros serviços de atendimento à infância pobre e abandonada. Embora inexistisse uma proposta de educação formal, essas instituições adotavam uma rotina fundada na autodisciplina, atividade de conto, memorização de rezas ou trechos bíblicos e atividades referentes à pré-escrita ou pré-leitura. O caráter moral e afirmação de bons hábitos eram enfatizados, pois nessa época concebia-se que tanto a família como instituições destinadas às crianças tinham como função corrigir as crianças nascidas do pecado.

Comênius (1592-1670), considerado o pai da didática, também trará importantes contribuições para a educação da criança. Segundo seus pressupostos, a educação inicia-se com o nascimento, sendo o meio familiar a primeira escola. Sua proposta de educação apresentava uma visão metafísica da educação, à qual caberia a criação de um modelo universal de homem virtuoso. Destaca em seus ideários pedagógicos a importância da educação dos sentidos e do contato da criança com elementos da natureza, bem como atividades relacionadas à gramática, música e poesia. Defendia também a presença dos contos de fadas, histórias da carochinha e narrativas, jogos, construtividade manual e música. A sua referência metodológica volta-se para o espontaneísmo e para o aprender fazendo (Rech, 2005, p.78).

No século XVIII, em pleno apogeu dos ideários do movimento iluminista, as ideias de Rousseau, contrárias ao pensamento conservador dos moralistas, irão revolucionar a educação da infância ao reconhecer a importância de se pensar a criança a partir de sua natureza específica e não mais como um adulto em miniatura.

Suas ideias defendiam uma educação fundamentada na liberdade, destacando a importância do ambiente e dos elementos da natureza. Partidário dos ideais humanistas, defendia uma educação que forjasse o pleno desenvolvimento e a felicidade do ser humano. Rousseau é conhecido como um dos precursores do movimento es- 
colovista, que tinha, entre seus pressupostos, a necessidade de uma pedagogia centrada na criança e pouca intervenção educativa.

Observa-se também que, para Rousseau, a ideia de tempo para aprender difere da conotação do tempo para Froebel, estabelecido por programas escolares ou atividades dirigidas como forma de aprender. Conforme Rech (2005, p.82), "sua preocupação com a infância e com a atitude das crianças é para conduzi-las de modo que resultem em adultos bons e felizes, iguais em direitos ao seus pares".

Como herança rousseauniana, temos a concepção de criança feliz, inocente, pura e ingênua.

Assim como Comênius, Pestalozzi (1746) acreditava que a família era o ponto inicial da educação do ser humano, a ser complementada pela educação escolar. Reconhecia as crianças como seres de impulsos, sem consciência de suas ações ou vontades. Segundo Oliveira (2005, p.65), para esse educador, a força vital da educação estaria na bondade e no amor e deveria ocorrer em um ambiente o mais natural possível. Sua pedagogia propunha uma atividade manual aliada à intelectual, preconizando uma educação para os sentidos, para a prontidão e para a organização gradual do conhecimento, ou seja, do mais simples ao mais complexo. Rech (2005, p.87) destaca que os exercícios de coordenação motora utilizados nas instituições de educação infantil são resultantes das propostas de exercícios e atividades de Pestalozzi.

$\mathrm{Na}$ visão desses três educadores, encontramos a leitura de uma educação infantil estimuladora dos sentidos e da infância reconhecida como etapa de vida a ser conduzida para a formação de homens bons e felizes.

Froebel (1782-1852), educador alemão, criador dos jardins de infância, será o precursor de uma proposta de educação infantil institucionalizada. Concebia a criança como semente da divindade, cabendo à educação a tarefa de deixá-la desabrochar: "educar, portanto, é despertar na criança por meio da atividade, a consciência que sua natureza tem da existência de Deus, orientando para uma vida 'santa e pura'” (Rech, 2005, p.88). O educador propõe dois 
períodos para o desenvolvimento infantil: o período da infância $(0$ a 2 anos) e o período da puerícia ( 3 a $6 / 7$ anos). No primeiro período, as atividades com as crianças deveriam ser direcionadas para os sentidos, para atividades motoras e para o desenvolvimento da linguagem. Já no segundo, reconhece-se o período de início da educação, visto que a criança já apresenta maior desenvolvimento sensorial da linguagem e brinquedo.

Nos jardins de infância, a proposta educacional incluía atividades de cooperação, os jogos e o aprender fazendo, bem como atividades de livre expressão como a música, construção com papel, argila e blocos de linguagem. Conforme destaca Oliveira (2005, p.67), os jardins de infância incluem uma dimensão pedagógica no trabalho com as crianças, ao contrário das instituições assistenciais da época.

No século XX, novas demandas apresentaram-se à educação com ênfase no fazer, no trabalho e na ação, adaptando o homem às novas rotinas da sociedade industrial. O fazer torna-se a tônica da ação educativa e o tempo destinado às atividades pedagógicas passa a ter um lugar de destaque.

Afinal, estabelecer horários para as atividades diversas nas instituições seria uma adequação às necessidades desse novo homem, pois desde cedo as crianças estariam se adaptando ao tempo dos relógios das fábricas e às doutrinas do trabalho, além de terem seu tempo ocupado nas instituições com diversos fazeres. (Rech, 2005, p.105)

Conforme Rech (2005, p.106), pensadores como Montessori, Freinet, Dewey e Decroly irão apresentar propostas específicas para a educação infantil, influenciados pelas concepções de uma educação útil, pois as crianças são reconhecidas como o futuro do mundo.

Montessori (1870-1952) apresenta uma concepção de educação infantil influenciada pelos aspectos biológicos e psicológicos, des- 
tacando a importância da liberdade, do ambiente e dos materiais pedagógicos no sistema educativo.

Freinet (1896-1966) concebe a criança como sujeito único, singular e detentor de direitos. O trabalho-jogo é o eixo central de sua pedagogia, para criar a relação entre atitude e prazer. Enfatizava a importância das experiências de aprendizagem no meio social, extrapolando os limites da sala de aula.

Segundo Oliveira (2005, p.77), embora Freinet não tenha trabalhado diretamente com as crianças pequenas, suas ideias causaram impactos nas práticas de creches e pré-escolas. Dentre as atividades propostas na ação educativa, estão o jornal mural, o livro da vida e a aula passeio.

Dewey (1859-1952) reconhece a criança como ser em desenvolvimento, enfatizando o valor da experiência na aprendizagem e a importância do conhecimento aplicado à vida prática.

[...] Assim educar não é um procedimento pelo qual se instrui as crianças para que reproduzam determinados conhecimentos, mas, sim, pôr a criança em contato com a cultura a que pertence, atribuindo à linguagem um papel importante no que diz respeito à transmissão do conhecimento, sendo por intermédio dela que se pode entrar em contato com toda a cultura acumulada por gerações passadas. (Rech, 2005, p.100)

Decroly (1871-1932) irá influenciar as práticas pedagógicas na educação infantil com a ideia dos centros de interesse. Apresentando uma concepção biológica das evoluções da criança, defendia que o conhecimento pela criança deveria partir de suas necessidades e depois para o conhecimento do meio (Rech, 2005, p.102).

Pensadores como Wallon (1879-1962), Piaget (1896-1980) e Vygotsky (1896-1934) também são referências para o trabalho das instituições de educação infantil no século XX. Suas teorias dizem respeito a uma perspectiva interacionista do desenvolvimento e aprendizagem infantil, ou seja, consideram que o desenvolvimento infantil está atrelado aos fatores hereditários e culturais. Embora 
apresentem divergências em seus postulados, contribuíram para mudanças nas práticas pedagógicas das instituições de educação infantil, especialmente por reconhecerem a criança enquanto sujeito ativo na produção do conhecimento, destacando a importância do processo de interação social para o desenvolvimento e aprendizagem do ser humano (Oliveira, 2005, p.123-32).

As considerações traçadas sobre os pressupostos desses teóricos nos ajudam a entender a organização das rotinas nas práticas das instituições de educação.

Conforme Rech (2005, p.106), "a leitura dos pensadores a que fizemos referência nos encoraja a reflexões sobre as práticas pedagógicas nas rotinas da educação infantil, principalmente na faixa etária de zero a três anos".

Barbosa, ao estudar as rotinas das instituições de educação infantil, constata a prática de políticas de homogeneização, implementadas por rotinas que desconsideram a visão de criança concreta e a diversidade de marcos teóricos sobre a infância, estabelecidas, quase sempre, a partir da perspectiva da Psicologia Evolutiva. Para a autora, a rotina é definida como categoria pedagógica que permite a estruturação do trabalho cotidiano das instituições de educação infantil:

[...] uma categoria pedagógica que os responsáveis pela educação infantil estruturam para, a partir dela, desenvolver o trabalho cotidiano nas instituições de educação infantil. As denominações dadas à rotina são diversas: horário, emprego do tempo, sequência de ações, trabalho dos adultos e das crianças, plano diário, rotina diária, jornada, etc. (Barbosa, 2006, p.35).

A autora faz a diferenciação entre cotidiano e rotina, ${ }^{12}$ e consideramos pertinente recorrer a suas explicações para melhor entendimento da dimensão da rotina na educação infantil. A rotina

12. O termo rotina é de origem francesca, rout, derivado da palavra do latim vulgar rupta (rota) e seus primeiros registros aparecem no século XV, na Idade Média. 
refere-se à organização do cotidiano, sendo, portanto, um dos elementos que integram esse cotidiano. O cotidiano, enquanto espaço-tempo para a vida humana, apresenta um conceito mais abrangente:

Pois tanto é nele que acontecem as atividades repetitivas, rotineiras, triviais, como também ele é o lócus onde há a possibilidade de encontrar o inesperado, onde há margem para a inovação, onde se pode alcançar o extraordinário do ordinário. (Lefebvre, 1984, p.51 apud Barbosa, 2006, p.37)

É importante considerarmos que a rotina, além de possibilitar a organização do cotidiano, contribui para a constituição de subjetividades, visto que é por meio dela que as crianças, desde pequenas, nas famílias e nas instituições de educação infantil, aprendem sobre os rituais e hábitos socioculturais da sociedade. Com base nos estudos da autora, podemos sintetizar alguns aspectos referentes às rotinas: rotina difere do cotidiano por não incluir o imprevisto; a rotina traz implícita uma noção de espaço e tempo; a rotina relaciona-se aos rituais, aos hábitos e às tradições; a rotina remete à ideia de repetição, de resistência ao novo; a rotina tem um caráter normatizador (Barbosa, 2006, p.45-6).

É com o projeto de modernidade e com a necessidade de formação de sujeitos adaptados aos tempos modernos que a infância e a educação das crianças foi rotinizada e institucionalizada. Segundo Barbosa, as rotinas nas instituições de educação infantil abrangem atividades de expressão, atividades dirigidas e atividades de higiene, representando a seleção, a articulação e delimitação de todas as atividades da vida cotidiana (Barbosa, 2006, p.116).

Haddad (1991, p.125) enfoca o caráter normatizador e inflexível das rotinas nas creches: "a creche é governada pela inflexibilidade e por uma rigidez de horários para brincar, para comer, e pelas tarefas maternas desagradáveis: tirar piolho, cortar as unhas e dar banho". 
Dutoit (1995, p.74 apud Barbosa, 2006) descreve a centralidade da rotina para as propostas pedagógicas das instituições de educação infantil:

\begin{abstract}
A rotina é considerada algo estanque, inflexível, até pela definição da própria palavra, porém ela é a espinha dorsal de uma creche e através dela são organizados o tempo, o espaço e o conjunto de atividades destinadas às crianças e aos educadores. [...] A rotina representa a concepção que se tem de educação, homem e sociedade e, principalmente a concepção de infância, porque traduz através dos fazeres o que se compreende de função de uma creche.
\end{abstract}

Conforme destaca Barbosa (2006, p.191), as rotinas das instituições de educação infantil exercem um papel determinante na construção das subjetividades:

[...] as rotinas pedagógicas da educação infantil agem sobre a mente, as emoções e o corpo das crianças e adultos. É importante que as conheçamos e saibamos como operam, para que possamos estar atentos às questões que envolvem nossas próprias crenças e ações. Afinal, reconhecer limites pode ajudar a enfrentá-las.

Nas entrevistas com as educadoras das creches, a rotina assumiu a centralidade das estratégias pedagógicas, embora, segundo os dados dos questionários, 37,74\% das entrevistadas afirmassem que a organização do trabalho pedagógico é realizada pelo planejamento e por projetos.

A sequência e atividades pedagógicas ocuparam o segundo lugar, num total de $28,30 \%$ dos sujeitos da pesquisa; a rotina apareceu em terceiro lugar totalizando, 18,86\%; depois foram citadas a observação, com 9,43\% e a brincadeira, com 5,67\%. 
Tabela 5 - Organização das práticas pedagógicas

\begin{tabular}{|l|c|c|}
\hline \multicolumn{1}{|c|}{ Estratégias pedagógicas } & Total de sujeitos & Porcentagem \\
\hline Planejamento e projetos & 20 & $37,74 \%$ \\
\hline Sequência e atividade pedagógica & 15 & $28,30 \%$ \\
\hline Rotina & 10 & $18,86 \%$ \\
\hline Observação & 5 & $9,43 \%$ \\
\hline Brincadeira & 3 & $5,67 \%$ \\
\hline Total & 53 & $100 \%$ \\
\hline
\end{tabular}

Apesar de não utilizarmos a observação como instrumento metodológico em nossa pesquisa, as representações sociais dos sujeitos entrevistados em relação a essa categoria nos permite afirmar a presença de uma concepção de rotina definida por um caráter normatizador, inflexível, disciplinador e de padronização de atividades.

As representações sobre as rotinas são apresentadas nas falas das educadoras:

A rotina não pode ser uma rotina, né? Eu acho que esse nome muitas vezes acaba tornando uma rotina. Eu acho que a rotina tem que ser sempre bem elaborada visando sempre o bem-estar da criança e a necessidade do grupo, mas nunca deixando isto levar a uma rotina porque a criança cansa, fica uma coisa assim, já sabe o que tem na segunda, o que tem na terça, assim, muitas vezes tem que dar uma remanejada nestas coisas e não deixar que vire uma rotina porque senão você não consegue o objetivo daquela proposta, daquela atividade que você quer realizar.

E para o educador é uma forma de se organizar de extrema importância, porque se amanhã eu preciso de um recorte de papel, de alguma coisa, hoje eu já tenho que me antecipar e deixar isto pronto. É uma forma do professor se organizar perante as atividades que ele vai desenvolver com os seus alunos. 
Não deixar para última hora e tudo mais. Então é uma forma de organizar e deixar tudo preparado até para não dar mais ansiedade para seu aluno, não deixar o aluno solto ali até que o professor se organize. (Dália)

Bom, a rotina, igual assim, com as crianças que eu trabalho, eles estão já até muito bem. Quando a gente vai tomar café, e eles sabem que depois do café a gente tem que ir para o vídeo.

Eu acho que a rotina tinha que ser assim... Sentar com as educadoras pra discutir como é, porque nós conhecemos mais as crianças, nós sabemos como tem que ser o trabalho.

E a coordenadora e a pedagoga conversam, vê em cada sala os horários, mas nunca vai dar certo, se for ver vai ter um horário em desvantagem, sempre vai ter um horário em desvantagem, sempre procurar assim variar de dia pra não ficar sempre aquela rotina. Porque os alunos cansam da rotina. Igual de manhã tomamos café, após o café tem o vídeo, após o vídeo tem o lanche, depois o parque, depois do parque volta pra sala, faz atividade, lava as mãos para o almoço. Depois do almoço tem a escovação dos dentes e depois a hora do sono. Depois da hora do sono eles vão acordando, vão trocando as fraldas, a gente vai para uma área externa, brinca ou fica na sala e dá um brinquedo, música e depois a gente janta, depois troca as fraldas, lava o rosto delas, as mãos para elas irem embora. (Rosa)

Eu acho importante principalmente para eles que são pequeninos. O trabalho fica mais organizado, não fica solto. A rotina é organizada desde que a creche abriu. Assim tem os horários e eu acho que até os meninos se adaptam melhor à rotina. Agora é hora do lanche, agora é hora de escovar os dentes, agora é hora de atividade. Ajuda na organização, até no comportamento também, a criança não fica tão ansiosa, o que será que vai acontecer agora, o que será que vai acontecer depois, ela não fica perdida. Tanto pra gente quanto pra eles. (Gardênia)

A rotina a gente costuma falar que ela é como se fosse um norte, um guia para nossa prática. Ela deve ser organizada de forma 
que eu possa melhor atender as crianças. Agora ter os horários certinhos, esse horário é o melhor horário para ser para esta turma, esse outro horário já é melhor pra você estar fazendo as atividades respeitando todos os que estão aqui dentro. (Íris)

[...] Então a rotina ela é igual, de manhã faz sempre a mesma coisa. Dois dias na semana faz a mesma coisa. Depois os outros dias também as mesmas coisas. Para elas poderem gravar e isto ficar com elas, porque se cada dia fizer uma coisa diferente elas não gravam, elas não aprendem. Então de 0 a 3 anos você tem sempre que estar repetindo, para elas poder gravar aquilo na mente. (Angélica)

As representações manifestadas sobre a rotina revelam uma concepção adultocêntrica, na qual o adulto é o centro da rotina, uma atenção ao controle dos tempos e dos espaços revelando uma preocupação com a provisoridade e com a ordem. A fala da educadora Rosa revela que a rotina é estabelecida pela coordenadora pedagógica e que, embora haja a sua participação, seu poder de decisão é limitado. Observa-se, ainda, a predominância de atividades relacionadas à higiene e alimentação, próximas ao discurso apresentado pela concepção assistencialista da educação infantil. A rotina, ao contrário de possibilitar as expressões das múltiplas linguagens e o exercício da produção de cultura, constitui-se em uma rotina que prioritariamente assegura ao adulto a organização do seu trabalho, atribuindo à criança a condição de fragilidade, de dependente e de ser incapaz de escolhas no espaço coletivo da creche. Pode-se perceber, ainda, uma rotina que nada favorece para que a criança possa exercer o papel de produtora de cultura, visto que as atividades são predeterminadas e homogeneizadas, nas quais todos devem fazer juntos as mesmas coisas: comer, dormir, assistir a vídeo, etc.

Nessa categoria, está ainda presente uma organização do trabalho pedagógico marcada pela realização de atividades e pelo reconhecimento da criança como "aluno". As educadoras entrevista- 
das afirmam que as atividades são propostas tendo como subsídios os Referenciais Curriculares Nacionais para a Educação Infantil e os projetos de trabalho pedagógicos.

Este semestre nós estamos trabalhando com um projeto de leitura. Cada sala está com um livro, a nossa sala está com a Dona Baratinha, mas é um projeto da creche inteira e no final do ano nós vamos fazer uma apresentação para os pais. Este é o projeto único da creche. Cada semestre é um projeto. (Gardênia)

Tem vários projetos que a gente desenvolve, nós mesmos, ou junto com a pedagoga ou ela mostra para a gente como faz e cada um vai fazendo para ir aprendendo também, tem vários projetos que a gente desenvolve. [...] a creche inteira tem um projeto. Só o berçário e o minigrupo às vezes faz diferente e adapta a sala. Mas cada uma tem o seu dia de fazer o projeto e adapta a cada sala, mas aí o projeto vai na mão de cada professora e ela que faz o seu plano de aula. Aí faz a rotina que é tomar café, depois escovar os dentes, ir pra sala, cantar, dá atividade pras crianças e cada um adapta do seu jeito, vai fazendo o seu plano. [...] hoje mesmo teve atividades que eles colaram aquário, primeiro a gente fez uma roda de conversa, aí fala os animaizinhos, aí eles perguntam, eles gostam muito, sabe?! Vamos começar também os meios de transporte, só que é sequência, não tem final, mas agora o projetinho não, o projetinho já tem o começo e o final certinho. (Angélica)

Eu acho que todos os eixos dos Referenciais Curriculares Nacionais para a Educação Infantil que são propostos pra gente trabalhar são importantes. Acho que não tem como destacar um deles como mais importante. A gente tem vários eixos: a linguagem oral e escrita, matemática, natureza e sociedade, o movimento, que é superimportante, especialmente para as crianças que a gente atende aqui. [...] esse ano foi trabalhado o projeto adaptação. No momento, a gente está trabalhando o peixinho do aquário, o planeta pede socorro, amor e ação que vai ser lançado 
agora com os pais, deixa eu ver outro... cantarolando e outros. (Íris)

A nossa rotina é bem corrida. [...] de manhã a gente tem um período que trabalha com lego, com massinha, com conto de história, com música. Na hora do banho é a estimulação das partes do corpo. [...] a gente não procura trabalhar muito assim papel com eles, a não ser amassar, folhear revista, essas coisas. Agora atividade prática, assim de registro não, mas a gente trabalha o estímulo, através do brinquedo, do faz de conta e do fantoche. (Dália)

[...] bom quando eu entrei aqui elas estavam trabalhando os sentidos. Aí o último projeto que nós trabalhamos foi o circo, trabalhamos mais o palhaço, porque nós fizemos uma festa aqui e as crianças ficaram com medo, então a pedagoga falou é hora de você começar a trabalhar. Então é assim, a gente vai começar a trabalhar o projeto água, a gente pode falar com eles o motivo que faltou água. A gente sempre tenta trazer um projeto assim. (Rosa)

Embora as entrevistadas sejam de creches diferentes, constata-se um padrão de rotina nas instituições pesquisadas, pois, segundo Barbosa (2006, p.177), "em sua função como organizadora e modeladora de sujeitos, a rotina diária na educação infantil segue um padrão fixo e universal na sua formulação, na sua estrutura e no modo de ser representada".

Como podemos perceber, a rotina das creches caracteriza um atendimento à criança de até 3 anos pautado em um modelo escolarizante, no qual predomina a ideia de manter a criança ocupada em atividades direcionadas pelo adulto, muitas vezes fragmentadas e sem conexão, enfatizando um trabalho pedagógico desenvolvido por áreas curriculares e por projetos de atividades.

Como revelam os dados de nossa pesquisa, as práticas pedagógicas desenvolvidas nas instituições priorizam o cumprimento de 
uma rotina previamente estabelecida, dificultando o espaço para o imprevisto, para o lúdico e para a interação social.

O compromisso com uma educação infantil cidadã implica a organização de uma rotina que permita às crianças o riso, a alegria, a criatividade, a autonomia, o prazer, o lúdico, a descoberta, enfim, o direito de ser criança. 


\section{CONSIDERAÇõES FINAIS}

Ou isto ou aquilo: ou isto ou aquilo... e vivo escolhendo o dia inteiro!

Não sei se brinco, não sei se estudo, se saio correndo ou fico tranquilo. Mas não consegui entender ainda qual é melhor: se é isto ou aquilo.

Cecília Meireles

A escolha da poesia de Cecília Meireles "Isto ou aquilo" como epígrafe das Considerações Finais justifica-se pelo caráter paradoxal que permeou a construção deste estudo, tanto no que se refere aos discursos teóricos quanto aos discursos revelados pelos sujeitos entrevistados.

Buscamos nesta pesquisa compreender as concepções de infância, direito e educação infantil apresentadas pelas educadoras das creches de Franca, considerando que as práticas profissionais desenvolvidas com as crianças são construídas a partir da representação social dessas categorias.

No transcorrer do nosso estudo, foi marcante o caráter complexo e contraditório da infância e do papel da criança na sociedade, 
revelando que as ideias, os valores e os conceitos acerca da infância foram construídos e modificados paralelamente às mudanças na dinâmica da sociedade. Portanto, diferentes formas de compreender, perceber e de se relacionar com as crianças foram sendo tecidas historicamente.

Atualmente, as crianças e as questões relacionadas à infância estão cada vez mais presentes nas agendas políticas, na mídia e nas investigações científicas. Porém, apesar da visibilidade dada a essas categorias, observa-se a ausência de políticas públicas que de fato sejam capazes de assegurar às crianças condições dignas de vida.

A reorganização do capitalismo contemporâneo, pautado nas políticas de reajuste da economia e nos impactos da globalização, acentuou as desigualdades sociais, o desemprego, a violência e, consequentemente, o acesso aos direitos sociais, tornando as crianças um dos segmentos mais vulneráveis à exploração e à miséria. Apesar das conquistas no campo legal, em que se circunscrevem os direitos da infância, tem-se registrado o aumento dos indicadores de violação desses direitos em quase todo o mundo.

Como afirmam Pinto \& Sarmento (1997, p.12), o caráter paradoxal é uma das constantes facetas da infância, sobretudo por ser atribuída às crianças a condição de futuro do mundo num presente de opressão.

Consideramos que o conhecimento das condições de vida da criança na sociedade contemporânea é fundamental aos profissionais que atuam com a infância, pois as crianças precisam de profissionais sensíveis à sua condição para que possam ter assegurados seus direitos fundamentais, garantindo melhores condições de vida numa conjuntura social cada vez mais opressora e excludente.

Percorrendo a história da infância, observamos a questão da construção de sucessivas representações sociais sobre essa categoria manifestadas no imaginário das pessoas, determinadas pelas condições históricas e por seus fatores econômicos, políticos, sociais e culturais.

Se, na modernidade, data-se o surgimento da infância e o reconhecimento da criança como sujeito social, constatam-se, também, 
as primeiras manifestações do caráter paradoxal revelado pela necessidade de normatização, institucionalização e preparação dessa criança para a vida adulta e produtiva. As primeiras representações acerca dessa categoria revelaram a imagem da criança como ser dependente, frágil, ignorante e vazio que deveria ser "educado" para exercer a condição de cidadão e de futuro trabalhador. Assim, o entendimento da infância como categoria da modernidade requer, também, o entendimento das mudanças das relações de produção suscitadas com o desenvolvimento do capitalismo.

Paralelamente ao reconhecimento da infância, surgiram conhecimentos e teorias propagadas por diversas áreas do saber para regulamentar e direcionar a vida das crianças nas famílias e nas instituições.

É nesse contexto histórico que surgem também as instituições destinadas ao atendimento da infância, primeiramente na Europa, no final do século XVIII, e, no Brasil, no fim do século XIX e início do século XX.

Embora tenhamos na pós-modernidade, ou, como afirma Sarmento (2007, p.34), segunda modernidade, a concepção de criança como sujeito de direitos, produtora de cultura, competente e forte, ainda estão presentes, nas práticas sociais direcionadas às crianças, as manifestações das representações da criança enquanto um "vir a ser", ser frágil e dependente do adulto.

Os dados de nossa pesquisa revelam nos discursos das educadoras das creches pesquisadas, majoritariamente, uma visão de infância herdada do ideário da modernidade, pautada pela visão romântica da infância e por uma concepção de criança reconhecida como indivíduo ingênuo, puro e inocente. Aliada a essa representação está a ideia da criança como recurso do futuro e adulto em espera (Moss, 2002, p.239). Essas representações também se manifestam nos discursos dos organismos internacionais que têm influenciado as atuais políticas de atendimento à infância no Brasil, a partir das últimas décadas do século XX.

As ações direcionadas às crianças, subjacentes ao discurso propagado por essas representações, evidenciam a presença de uma 
visão adultocêntrica no contexto das creches, no qual o poder de decisão emana do adulto, ocupando este o papel principal no cenário institucional, restando às crianças exercer o papel de sujeitos passivos e dependentes. Esse fato revela o caráter paradoxal acerca do discurso legal e pedagógico em defesa dos direitos da infância e da condição de sujeito social da criança.

Torna-se importante destacar a urgência da desconstrução dessa visão de criança, o que implica a necessidade de estudos teóricos e formação desses profissionais.

É preciso que as crianças sejam reconhecidas como tendo uma condição infantil e não meramente por sua natureza infantil, o que requer o rompimento com políticas de atendimento que consideram a criança como objeto de tutela e proteção, que precisa ser guiada e controlada por um sujeito mais experiente.

A fragilidade física das crianças, sem dúvida, exige cuidados nos espaços institucionais, porém não pode ser negada às crianças a condição de sujeitos que produzem cultura e constroem conhecimentos no processo de interação social. Dessa forma, o projeto pedagógico das instituições de educação infantil precisa priorizar as práticas que favorecem as expressões das múltiplas linguagens das crianças, organizadas em tempos e espaços que favoreçam a superação da lógica adultocêntrica.

A condição da criança como sujeito nesses espaços institucionais está atrelada, ainda, ao rompimento com os modelos de atendimento herdados das políticas assistencialistas e dos modelos pedagógicos preparatórios para o ensino fundamental. É preciso que nos discursos e nas ações dos profissionais das instituições de educação infantil as crianças sejam reconhecidas como sujeitos de direitos no tempo presente e não enquanto futuros cidadãos. Podemos, ainda, afirmar a necessidade de que em toda a sociedade as crianças possam ser respeitadas nessa condição tão peculiar de sujeitos em desenvolvimento.

Embora a maioria dos sujeitos da pesquisa tenha formação estabelecida pela LDB para o desempenho de suas funções, ou seja, formação na modalidade normal, nível Magistério e na Pedagogia, 
constata-se que os cursos de formação inicial não foram suficientes para construção de imagens que sustentem um lugar de relevância às crianças no cenário das creches.

Entendemos ainda a importância de que os serviços de formação continuada desses profissionais possibilitem a construção de novos saberes sobre as crianças, resgatando a história da infância e favorecendo a ruptura com os paradigmas até então construídos acerca desse conceito.

Podemos compreender que o modelo teórico construído sobre a infância tem um rebatimento nas práticas pedagógicas desenvolvidas nas instituições de educação infantil, visto que o entendimento do que seja a criança e a sua educação serão determinantes para as vivências nas instituições. Os discursos das educadoras entrevistadas, embora afirmassem o reconhecimento da educação infantil como um dos direitos das crianças, paradoxalmente, revelaram representações de uma educação infantil preparatória e alicerce para as aprendizagens futuras. A criança, em vez de ser reconhecida na sua condição infantil, é entendida como aluno; priorizam-se os processos de ensino-aprendizagem em detrimento das relações educativas que se desenvolvem nesses espaços coletivos, comprometendo a efetivação da pedagogia da infância (Rocha, 1998, p.60).

A presença desse modelo de educação infantil reflete os desafios e os impasses para a integração das creches nos sistemas de ensino. Os profissionais dessas instituições, no desejo de romper com a herança assistencialista que permeou por muito tempo a história das creches, acreditam que o pedagógico seja a implantação do modelo próximo à escolarização. Dessa forma, as funções de cuidar e educar, propagadas como funções básicas da educação infantil, são substituídas por um modelo de educação escolarizante, no qual há presença marcante de uma rotina rígida formada por sucessivas atividades que nem sempre atendem aos reais interesses e necessidades das crianças.

$\mathrm{Na}$ busca de desvendar o cotidiano e as práticas pedagógicas dessas instituições, encontramos na organização dessas práticas um 
modelo de rotina caracterizado por um aspecto normatizador, inflexível, disciplinador e de padronização de atividades.

Foi marcante a ruptura entre o cuidar e o educar na organização das práticas pedagógicas, estando ausente nos discursos apresentados nas entrevistas a importância das ações que contemplem, de forma indissociável, o cuidar e o educar no atendimento às crianças. Ao contrário, as entrevistas revelaram uma acentuada preocupação com o educar, porém no sentido de sistematização de atividades preparatórias para futuras aprendizagens. Nessa preocupação com o educar foi evidenciada a presença das Referências Curriculares Nacionais para a Educação Infantil como subsídio na elaboração dos projetos pedagógicos, não sendo mencionadas as Diretrizes Curriculares Nacionais para a Educação Infantil, enquanto documento mandatário para a elaboração das propostas pedagógicas das instituições de educação infantil.

Dentre as críticas tecidas por muitos teóricos em relação aos Referenciais Curriculares está o risco da implantação de práticas pedagógicas engessadas, rotineiras, que muitas vezes desconsideram o universo cultural das crianças e a existência de múltiplas formas de viver a condição da infância em nosso país, o que acaba por negar o direito das crianças a uma educação infantil emancipatória.

No Brasil, assim como em outros países, têm sido intensificadas as lutas pelo direito das crianças à educação infantil, reflexo do reconhecimento do significado dos primeiros anos de vida para o desenvolvimento e educação do ser humano.

Essa consciência social tem influenciado as políticas públicas direcionadas à infância e as políticas educacionais, especialmente a partir da Declaração Mundial de Educação para Todos, em 1990, na qual é afirmada a ideia de que a educação inicia-se com o nascimento.

Nos últimos anos foi significativo o número de documentos oficiais elaborados e divulgados pelo Ministério da Educação no intuito de que seja efetivada uma Política de Educação Infantil no país. Dentre os pressupostos dessa política estão o reconhecimento da infância como etapa relevante no processo de construção da ci- 
dadania, as funções indissociáveis de cuidar e educar, o oferecimento da educação infantil em complementação à ação da família, o lúdico como elemento constitutivo das práticas pedagógicas nas instituições de educação infantil, a formação adequada dos profissionais, o acesso às instituições de educação infantil e, sobretudo, a garantia de uma educação de qualidade pautada nos direitos fundamentais da infância.

É fato recente no Brasil a inclusão da educação infantil como primeira etapa do sistema educacional, preconizada pela Constituição Federal de 1988 e reiterada pela LDB. Com o atual quadro normativo que rege a educação infantil, as creches, historicamente construídas como lugar da assistência e do atendimento à infância desvalida, é legitimada como instituição educativa.

Porém, em nossa pesquisa, esse quadro normativo é superficialmente conhecido, estando ainda presente no imaginário de algumas das entrevistadas a ideia da creche como espaço que substitui a ausência da família e de assistência às crianças.

Dessa forma, podemos afirmar que as representações atuais das educadoras das creches em relação às crianças, seus direitos e sua educação não são suficientes para que possamos ter assegurada a condição da criança como sujeito de direitos.

Esta pesquisa pode traçar ainda, de forma inicial, o perfil da política de atendimento das creches no município de Franca. Estudos têm mostrado que a efetivação do direito da criança pequena à educação implica a garantia de ofertas que atendam às diversidades por parte do poder público, rompendo com a herança histórica da oferta do atendimento realizado por entidades filantrópicas e assistenciais.

Com a nova LDB, a educação infantil passou a ser reconhecida como parte do sistema municipal de educação, o que retirou as creches da área da assistência. Constatamos que em nosso município a integração das creches à Secretaria Municipal de Educação foi parcialmente realizada, visto que grande número de creches da cidade ainda é gerido por instituições filantrópicas conveniadas com o poder público. 
Esse fato reitera a presença de grupos religiosos ou de serviços na gestão das instituições, tornando presente a ideia da instituição como favor ou ajuda aos mais necessitados.

Como vimos, o quadro legal enfatiza a responsabilidade do poder público municipal no oferecimento dos serviços de educação infantil, portanto, o atual convênio entre a prefeitura e as creches não legitima o direito das crianças à educação infantil, que, embora seja uma opção da família, deve ser uma obrigação do Estado.

A questão do direito da criança à educação infantil tem sido amplamente discutida no que se refere ao direito ao acesso e à qualidade do atendimento das creches e pré-escolas. Apesar do número de creches da cidade de Franca ter aumentado significatimente nos últimos dois anos, ainda temos uma grande parcela da população infantil desprovida do direito à educação. Outro aspecto diz respeito aos recursos financeiros. O financiamento da educação infantil é um dos entraves e desafios da política dessa área. Com o Fundeb, creches e pré-escolas foram incluídas no montante de repasse do governo federal para os municípios, os quais deverão investir na ampliação do atendimento à educação infantil.

A qualidade do atendimento perpassa fatores relacionados à infraestrutura, aos equipamentos, à razão adulto-criança, mas, sobretudo, à formação dos profissionais que atuam diretamente com as crianças. Apesar de a formação inicial desses profissionais ser satisfatória, é preciso que a formação continuada contribua para um novo olhar à criança e à educação infantil, enfatizando o lúdico no trabalho pedagógico e promovendo que as creches sejam verdadeiros espaços de encontros humanos, aprendizagens, vivências, fantasias e, especialmente, onde possam ser garantidos os direitos não somente de provisão e proteção, mas de participação. Cabe ressaltar a ausência de uma política de valorização desses profissionais, quer na parte salarial, quer no reconhecimento legal como docentes da educação infantil.

É preciso romper com os paradoxos que têm marcado a história da infância, seus direitos e sua educação, revelados pelas constantes 
opções entre isto ou aquilo, ou seja, "vir a ser" ou cidadão, tutela ou cidadania, assistencial ou escolarizante.

É fundamental que seja intensificada a luta pelo reconhecimento da condição da criança como sujeito de direitos, em especial a uma educação infantil de qualidade que assegure a ela a sua condição de ser criança e sujeito protagonista nos espaços institucionais. 



\section{REFERÊNCIAS BIBLIOGRÁFICAS}

ABRAMOVAY, M., KRAMER, S. O rei está nu: um debate sobre as funções da pré-escola. Cadernos Cedes (São Paulo), n.9, p.27-38, 1991.

ALMEIDA, D. S. de O. e. Educação infantil: um estudo contrastivo. Franca, 2008, 357 f. Tese (livre docência) - Faculdade de História, Direito e Serviço Social, Universidade Estadual Paulista "Júlio de Mesquita Filho".

ANDRADE, L. B. P. de. Os Centros de Convivência Infantil da UNESP: contexto e desafios. Franca, 2003, 145 f. Dissertação (mestrado em Serviço Social) - Faculdade de História, Direito e Serviço Social, Universidade Estadual Paulista "Júlio de Mesquita Filho".

ANDRADE, M. A. R. A. de. A creche enquanto espaço de ações das políticas públicas destinadas à infância. Serviço Social $e$ Realidade (Franca), v.13, n.2, p.79-88, 2004.

ANDRADE, M. A. R. A. de. Pensar e repensar a formação profissional: a experiência do curso de Serviço Social da Faculdade de História, Direito e Serviço Social - UNESP - Franca. Franca, 2007, 179 f. Tese (livre-docência) - Faculdade de História, Direito e Serviço Social, Universidade Estadual Paulista "Júlio de Mesquita Filho".

ANDREOTTI NETO, N. (Coord.). Consolidação das leis trabalhistas (CLT). São Paulo: Rideel, 1992. (Leis Rideel). 
ANGOTTI, M. Educação infantil: para que, para quem e por quê. In: . (Org.). Educação infantil: para que, para quem e por quê? Campinas: Alínea, 2006.

ARIÈS, Philippe. História social da criança e da família. Trad. Dora Flaksman. 2.ed. Rio de Janeiro: Guanabara, 1986.

ARROYO, M. G. O significado da infância. In: SIMPÓSIO NACIONAL DE EDUCAÇÃO INFANTIL, I. Brasília, DF, 1994. Anais... Brasília, DF: MEC, 1994. p.88-92.

ASSIS, R. de. Educação infantil e propostas pedagógicas. In: BRASIL. Ministério da Educação e do Desporto. Secretaria de Educação Fundamental. Subsídios para credenciamento de instituições de educação infantil. v.2. Brasília, DF: MEC/SEF/Coedi, 1998.

BARBOSA, M. C. S. Por amor e por força: rotinas na educação infantil. Porto Alegre: Artmed, 2006.

BARDIN, L. Análise de conteúdo. Trad. Luís Antero Reto e Augusto Pinheiro. Lisboa: 70, 2000.

BAZILIO L. C., KRAMER, S. Infância, educação e direitos humanos. São Paulo: Cortez, 2003.

BOBBIO, N. A era dos direitos. 19.ed. Rio de Janeiro: Elsevier, 1992.

BRASIL. Câmara de Educação Básica. Conselho Nacional de Educação. Parecer n. CEB 22/98, de 17 de dezembro de 1998. Aprova as diretrizes curriculares nacionais para a educação infantil. Brasília, DF, 1998. Disponível em <http://www.crmariocovas.sp. gov.br/pdf/diretrizes_p0481-0500_c.pdf>. Acesso em 12/2/2009.

. Câmara de Educação Básica. Conselho Nacional de Educação. Parecer n. CNE 4/2000, de 16 de fevereiro de 2000. Aprova as diretrizes operacionais para a educação infantil. Brasília, DF, 2000. Disponível em <http://www.crmariocovas.sp.gov.br/pdf/diretrizes_p0619-0628_c.pdf>. Acesso em 12/2/2009.

. Constituição (1988). Constituição da República Federal do Brasil. Brasília, DF: Senado Federal, 1988.

Decreto-lei n. 5.452, de 1으 de maio de 1943. Aprova a Consolidação das Leis do Trabalho. Diário Oficial [da] República Federativa do Brasil. Brasília, DF, 14/9/2001, p.11.937. Disponível em <http://www.planalto.gov.br/ccvil/Decreto-Lei/Del5452. htm>. Acesso em 4/1/2009. 
BRASIL. Lei n. 8.069, de 13 de julho de 1990. Dispõe sobre o Estatuto da Criança e do Adolescente e dá outras providências. Diário Oficial [da] República Federativa do Brasil. Brasília, DF, 16/7/1990, p.13.563. Disponível em <http://www.planalto.gov. $\mathrm{br} /$ ccvil/LEIS/L8069.htm>. Acesso em 2/2/2009.

Lei n. 9.394, de 20 de dezembro de 1996. Estabelece as diretrizes e bases da educação nacional. Diário Oficial [da] República Federativa do Brasil. Brasília, DF, 23/12/1996, p.27.833. Disponível em <http://www.planalto.gov.br/ccvil_03/LEIS/19394. htm $>$. Acesso em 10/2/2009.

Lei n. 10.172, de 9 de janeiro de 2001. Aprova o Plano Nacional de Educação e dá outras providências. Diário Oficial [da] República Federativa do Brasil. Brasília, DF, 10/1/2001, p.1. Disponível em <http://www.diariooficial.hpg.com.br/plano_nac_ educacao.htm>. Acesso em 26/3/2009.

Ministério da Educação e do Desporto. Secretaria da Educação Fundamental. Critérios para o atendimento em creches que respeite os direitos fundamentais das crianças. Brasília, DF: MEC/SEF/ Coedi, 1997.

Ministério da Educação e do Desporto. Secretaria da Educação Fundamental. Referencial Curricular Nacional para Educação Infantil. v.1-3. Brasília, DF: MEC/SEF/Coedi, 1998.

. Ministério da Educação e do Desporto. Secretaria da Educação Fundamental. Subsidios para credenciamento e o funcionamento das instituições de educação infantil. v.2. Brasília, DF: MEC/SEF/ Coedi, 1998.

Ministério da Educação e do Desporto. Secretaria de Educação Fundamental. Política Nacional de Educação Infantil. Brasília, DF: MEC/SEF/DPEF/Coedi, 1994.

Ministério da Educação. Conselho Nacional de Educação. Resolução CEB n. 1, de 7 de abril de 1999. Institui as Diretrizes Curriculares Nacionais para a Educação Infantil. Diário Oficial [da] República Federativa do Brasil. Brasília, DF, 13/4/1999. Disponível em <http://www.portal.mec.gov.br/cne/arquivos/pdf/ CEB0199.pdf>. Acesso em 25/5/2009. 
BRASIL. Ministério da Educação. Secretaria de Educação Básica. Parâmetros Nacionais de Qualidade para Educação Infantil. v.1 e 2. Brasília, DF: MEC/SEB, 2006.

Ministério da Educação. Secretaria de Educação Básica. Parâmetros Básicos de Infraestrutura para Instituições de Educação Infantil. Brasília, DF: MEC/SEB, 2006.

Ministério da Educação. Secretaria de Educação Básica. Política Nacional de Educação Infantil: pelos direitos das crianças de zero a seis anos à educação. Brasília, DF: MEC/SEB, 2006.

BUJES, M. I. E. Escola infantil: pra que te quero? In: CRAIDY, C., KAERCHER, G. E. Educação infantil: para que te quero? Porto Alegre: Artmed, 2001.

CAMPOS, M. M. A legislação, as políticas nacionais de educação infantil e a realidade: encontros e desafios. In: MACHADO, M. L. A. (Org.). Encontros e desencontros em educação infantil. São Paulo: Cortez, 2002.

ROSEMBERG, F., FERREIRA, I. Creches e pré-escolas no Brasil. 2.ed. São Paulo: Cortez, FCC, 1995.

, FULGRAFF, J. B. G., WIGGERS, V. A qualidade da educação infantil: alguns resultados de pesquisa. Cadernos de Pesquisa (São Paulo), n.127, p.87-128, jan.-abr. 2006.

CARR, E. H. Que é história? Trad. Lúcia Maurício de Alverga. 3.ed. São Paulo: Paz e Terra, 1996.

CERISARA, A. B. A produção acadêmica na área da educação infantil a partir da análise de pareceres sobre o Referencial Curricular Nacional da Educação Infantil. In: FARIA, A. L. G. de., PALHARES, M. S. (Org.). Educação infantil pós-LDB: rumos e desafios. 2.ed. Campinas: Autores Associados, 2000. p.19-49. (Polêmica do nosso tempo, 62).

. O Referencial Curricular Nacional para a Educação Infantil no contexto das reformas. Educação E Sociedade (Campinas), v.23, n. 80, p.329-48, set. 2002.

. Por uma pedagogia da educação infantil: desafios e perspectivas para os professores. In: BARBOSA, R. L.L.(Org.). Trajetórias e perspectivas da formação de educadores. São Paulo: Unesp, 2004. 
CHARLOT, B. A mistificação pedagógica: realidades sociais e processos ideológicos na teoria da educação. Trad. Ruth Rissin Josef. Rio de Janeiro: Zahar, 1986.

CIVILETTI, M. V. P. O cuidado às crianças pequenas no Brasil escravista. Cadernos de Pesquisa (São Paulo), n.76, p.31-40, fev. 1991.

COLIN, D. R. A., FOWLER, M. B. LOAS: Lei Orgânica da Assistência anotada. São Paulo: Veras, 1999. (Núcleos de pesquisa, 4).

CONSULTA sobre qualidade de educação infantil: o que pensam e querem os sujeitos deste direito. São Paulo: Cortez, 2006.

CORAZZA, S. M. Infância E educação: era uma vez... quer que conte outra vez? Petrópolis: Vozes, 2002.

COSTA, A. C. G. De menor a cidadão. In: COSTA, A. C. G., MENDEZ, É. G. Das necessidades aos direitos. pte.2. São Paulo: Malheiros, 1994. (Série Direito da criança, 4).

CRAIDY, C. M. A educação da criança de 0 a 6 anos: o embate assistência e educação na conjuntura nacional e internacional. In: MACHADO, M. L. A. de (Org.). Encontros e desencontros em educação infantil. São Paulo: Cortez, 2002.

KAERCHER, G. E. Educação infantil: para que te quero? Porto Alegre: Artmed, 2001.

CURY, C. R. J. A educação infantil como direito. In: BRASIL. Ministério da Educação e do Desporto. Secretaria de Ensino Fundamental. Subsídios para credenciamento e funcionamento de instituições de educação infantil. v.2. Brasília, DF: MEC/SEF, 1998.

A educação infantil: bases legais de financiamento. In: SIMPÓSIO DE EDUCAÇÃO INFANTIL: construindo o presente. Brasília, DF, 2002. Anais... Brasília, DF: UNESCO, 2003. p.183-90. Disponível em <http://www.dominiopublico.gov.br/download/texto/ue000311.pdf>. Acesso em 26/5/2009.

. Legislação educacional brasileira. Rio de Janeiro: DP\&A, 2002.

DAHLBERG, G., MOSS, P., PENCE, A. Qualidade na educação da primeira infância: perspectiva pós-moderna. Porto Alegre: Artmed, 2003. 
DECLARAÇÃO mundial sobre educação para todos e plano de ação para satisfazer as necessidades básicas de aprendizagem. UNESCO, 1990. Disponível em <http://unesdoc.unesco.org/ images/0008/000862/086291por.pdf>. Acesso em 20/5/2009.

DEMO, P. A nova LDB: ranços e avanços. 12.ed. Campinas: Papirus, 1997. (Magistério formação e trabalho pedagógico).

A política de educação infantil no contexto da política da infância no Brasil. In: SIMPÓSIO NACIONAL DE EDUCAÇÃO INFANTIL, 1. Brasília, DF, 1994. Anais... Brasília, DF: MEC, 1994. p.22-7.

DIDONET, V. Creche: a que veio... para onde vai... Em Aberto (Brasília, DF), v.18, n.73, p.11-28, jul. 2001.

. Importância da educação infantil. In: SIMPÓSIO DE EDUCAÇÃO INFANTIL: construindo o presente. Brasília, DF, 2002. Anais... Brasília: UNESCO, 2003. p.83-97. Disponível em <http:// www.dominiopublico.gov.br/download/texto/ue000311.pdf>. Acesso em 26/5/2009.

DOTTA, L. T. Representações sociais do ser professor. São Paulo: Alínea, 2006.

EDUCAÇÃO para todos: o compromisso de Dakar. Brasília: UNESCO/ CONSED, 2001. Disponível em <http://unesdoc.unesco.org/ images/0012/001275/127509porb.pdf > . Acesso em 20/5/2009.

FARIA, A. L. G. Políticas de regulação, pesquisa e pedagogia na educação infantil, primeira etapa da educação básica. Educação e Sociedade (Campinas), v.26, n.92, p.1.013-38, out. 2005. Disponível em <http://www.scielo.br/pdf/es/v26n92/v26n92a14.pdf>. Acesso em 15/6/2009.

PALHARES, M. S. (Org.). Educação infantil pós-LDB: rumos e desafios. Campinas: Autores Associados, 2000. (Polêmica do nosso tempo, 62).

FARR, R. Representações sociais: a teoria e sua história. In: GUARESCHI, P., JOVCHELOVITCH, S. (Org.). Textos em representações sociais. 6.ed. Petrópolis: Vozes, 2000. p.31-59.

FERREIRA, A. B. de H. Novo Aurélio século XXI: o dicionário de língua portuguesa. 3.ed. rev. e ampl. Rio de Janeiro: Nova Fronteira, 1999. 
FLEURY, M. das G. Há uma criança dentro da professora? In: OLIVEIRA, Z. de M. R. et al. Educação infantil: muitos olhares. São Paulo: Cortez, 1995.

FRABBONI, F. A escola infantil entre a cultura da infância e a ciência pedagógica e didática. In: ZABALZA, M. A. Qualidade em educação infantil. Porto Alegre: Artmed, 1998.

FULLGRAF, J. B. G. A infância de papel e o papel da infância. Florianópolis, 2001, 141 f. Dissertação (mestrado em Educação) Centro de Ciências da Educação, Universidade Federal de Santa Catarina.

GAGNEBIN, J. M. Infância e pensamento. In: GHIRALDELLI JÚNIOR, P. (Org.). Infância, escola e modernidade. São Paulo: Cortez, 1997.

GARCIA, P. B. Paradigmas em crise e a educação. In: BRANDÃO, Z. (Org.). A crise dos paradigmas e a educação. 3.ed. São Paulo: Cortez, 1996. (Questões de nossa época, 35).

GEIS, R. M. Criar ou educar crianças? Estudo das representações de mães e de educadoras sobre o papel da creche. São Paulo, 1994, 223 f. Tese (doutorado em Psicologia) - Instituto de Psicologia da Universidade de São Paulo.

GHIRALDELLI JÚNIOR, P. (Org.). Infância, escola e modernidade. São Paulo: Cortez; Curitiba: UFPR, 1997.

GIAQUETO, A. Caminhos para a proteção integral da criança e do adolescente: o caso de Franca. Franca, 2004, 207 f. Tese (doutorado em Serviço Social) - Faculdade de História, Direito e Serviço Social, Universidade Estadual Paulista "Júlio de Mesquita Filho".

GIDDENS, A. As consequências da modernidade. Trad. Raul Ficker. São Paulo: Ed. Unesp,1991.

GIL, A. C. Métodos e técnicas de pesquisa social. 5.ed. São Paulo: Atlas, 1999.

GOHN, M. da G. M. A força da periferia: a luta de mulheres por creches em São Paulo. Petrópolis: Vozes, 1985.

GOUVÊA, M. C. S. Infância, sociedade e cultura. In: CARVALHO, A., SALlES, F., GUIMARÃES, M. (Org.). Desenvolvimento e aprendizagem. Belo Horizonte: Ed. PROEX-UFMG, 2003. 
HADDAD, L. A creche em busca de identidade. São Paulo: Loyola, 1991.

Políticas integradas de educação e cuidado infantil: desafios, armadilhas e possibilidades. Cadernos de Pesquisa (São Paulo), v.36, n.129, p.519-46, dez. 2006.

. Substituir ou compartilhar? O papel das instituições de educação infantil no contexto da sociedade contemporânea. In: MACHADO, M. L. A. (Org.). Encontros e desencontros em educação infantil. São Paulo: Cortez, 2002.

OLIVEIRA, E. C. de. Secretaria do Bem-Estar Social e a creche: dos primórdios a 1970. Serviço Social E Sociedade (São Paulo), v.11, n.34, p.90-117, dez. 1990.

HARVEY, D. Condição pós-moderna: uma pesquisa sobre as origens da mudança cultural. 16.ed. Trad. Adail Ubirajara Sobral e Maria Stela Gonçalves. São Paulo: Loyola, 2008.

INSTITUTO BRASILEIRO DE GEOGRAFIA E ESTATÍSTICA. Cidades. Disponível em <http://www.ibge.gov.br/cidadesat/topwindow.htm?1>. Acesso em 13/4/2009.

Síntese dos indicadores sociais: uma análise das condições de vida da população brasileira. Estudos E Pesquisas: informação demográfica e socioeconômica, n.23. Rio de Janeiro, 2008. Disponível em <http://www.ibge.gov.br/home/estatistica/populacao/ condicaodevida/indicadoresminimos/sinteseindicsociais2008/ indic_sociais2008.pdf > . Acesso em 3/6/2009.

IZUMI, N. S. A atuação dos assistentes sociais nas creches de Franca. Franca, 2005, 117 f. Trabalho de Conclusão de Curso (bacharel em Serviço Social) - Faculdade de História, Direito e Serviço Social, Universidade Estadual Paulista "Júlio de Mesquita Filho".

JAVEAU, C. Criança, infância(s), crianças: que objetivo dar a uma ciência social da infância? Educação e Sociedade (Campinas), v.26, n.91, p.379-89, ago. 2005.

KISHIMOTO, T. M. Educação infantil integrando pré-escolas e creches na busca de socialização da criança. In: VIDAL, D. G., HILDSDORF, M. L. S. Brasil 500 anos: tópicos em história da educação. São Paulo: Edusp, 2001. 
KRAMER, S. (Org.). Infância e educação infantil. Campinas: Papirus, 1999.

- A política da pré-escola no Brasil: a arte do disfarce. Rio de Janeiro: Achiamé, 2003a.

Direitos da criança e projeto político pedagógico de educação infantil. In: BAZILIO L. C., KRAMER, S. Infância, educação e direitos humanos. São Paulo: Cortez, 2003b.

Infância, Estado e sociedade no Brasil. In: CONFERÊNCIA BRASILEIRA DE EDUCAÇÃO, 5. Brasília, DF, 1988. Anais... Brasília, DF: MEC, 1988. p.199-206.

KUHLMANN JÚNIOR, M. Educação infantil e currículo. In: FARIA, A. L. G., PALHARES, M. S. (Org.). Educação infantil pós-LDB: rumos e desafios. Campinas: Autores Associados, 2000b. (Polêmica do nosso tempo, 62).

Histórias da educação infantil brasileira. Revista Brasileira de Educação (São Paulo), n.14, p.5-18, mai.-ago. 2000a. Disponível em <http://www.anped.org.br/rbe/rbedigital/RBDE14/ RBDE14_03_MOYSES_KUHLMANN_JR.pdf $>$. Acesso em 20/5/2009.

Infância e educação infantil: uma abordagem histórica. 2.ed. Porto Alegre: Mediação, 2001.

LEITE FILHO, A. Proposições para uma educação infantil cidadã. In: GARCIA, R. L., LEITE FILHO, A. (Org.). Em defesa da educação infantil. Rio de Janeiro: DP\&A, 2001.

LIBÂNEO, J. C. Pedagogia e modernidade: presente e futuro da escola. In: GHIRALDELLI JÚNIOR, P. (Org.). Infância, escola e modernidade. São Paulo: Cortez, 1997.

, OLIVEIRA, J. F., TOSCHI, M. S. Educação escolar: políticas, estrutura e organização. São Paulo: Cortez, 2003. (Docência em formação).

LÜDKE, M., ANDRÉ, M. E. D. A. Pesquisa em educação: abordagens qualitativas. São Paulo: EPU, 1986.

MACHADO, M. L. de A. (Org.). Encontros e desencontros em educação infantil. São Paulo: Cortez, 2002.

MARCÍLIO, M. L. A lenta construção dos direitos da criança brasileira. SéculoXX. Revista USP(São Paulo), n.37, p.46-57, mai. 1998. 
MARTINS FILHO, A. J. (Org.). Criança pede respeito: temas em educação infantil. Porto Alegre: Mediação, 2005.

Culturas da infância: traços e retratos que as diferenciam. In: MARTINS FILHO, A. J. (Org.). Criança pede respeito: temas em educação infantil. Porto Alegre: Mediação, 2005.

MATTIOLI, O. C. No reino da ambiguidade. São Paulo, 1988, 153 f. Dissertação (mestrado em Psicologia Escolar) - Faculdade de Psicologia, Universidade de São Paulo.

MEIRELES, C. Ou isto ou aquilo. 5.ed. São Paulo: Nova Fronteira, 2003.

MERISSE, A. Origens das instituições de atendimento à criança pequena: o caso das creches. In: et al. Lugares da infância: reflexões sobre a história da criança na fábrica, creche e orfanato. São Paulo: Arte \& Ciência, 1997.

MINAYO, M. C. de S. Ciência, técnica e arte: o desafio da pesquisa social. In: (Org.). Pesquisa social. 17.ed. Rio de Janeiro: Vozes, 2000b.

O conceito de representações sociais dentro da sociologia clássica. In: GUARESCHI, P., JOVCHELOVITCH, S. (Org.). Textos em representações sociais. 4.ed. Petrópolis: Vozes, 2000a.

$O$ desafio de conhecimento: pesquisa qualitativa em saúde. 8.ed. São Paulo: Hucitec; Rio de Janeiro: Abrasco, 2004.

MONTENEGRO, T. O cuidado e a formação moral na educação infantil. São Paulo: Educ, 2001.

MOREIRA, E. M., VASCONCELLOS, K. E. L. Infância, infâncias: o ser criança em espaços socialmente distintos. Serviço Social E Sociedade (São Paulo), ano 24, n.76, p.165-80, nov. 2003.

MOVIMENTO INTERFÓRUNS DE EDUCAÇÃO INFANTIL DO BRASIL-MIEIB. Educação infantil construindo o presente. Campo Grande, MS: UFMS, 2002. Disponível em <http://www. mieib.org.br/i/livro_mieib.pdf>. Acesso em 30/5/2009.

MOSS, P. Reconceitualizando a infância: crianças, instituições e profissionais. In: MACHADO M. L. de A. (Org.). Encontros e desencontros em educação infantil. São Paulo: Cortez, 2002.

MOSCOVICI, S. A representação social da psicanálise. Rio de Janeiro: Zahar, 1978. 
OLIVEIRA, V. B. O brincar e a criança do nascimento aos 6 anos. São Paulo: Vozes, 2002.

OLIVEIRA, Z. de M. R. A creche no Brasil: mapeamento de uma trajetória. Revista da Faculdade de Educação (São Paulo), v.14, n.1, p.43-52, jan.-jun. 1988.

. Creches no sistema de ensino. In: MACHADO, M. L. de A. (Org.). Encontros e desencontros em educação infantil. São Paulo: Cortez, 2002.

. Educação infantil: fundamentos e métodos. 2.ed. São Paulo: Cortez, 2005. (Docência em formação).

, FERREIRA, M. C. R. Propostas para atendimento em creches no município de São Paulo. Histórico de uma realidade. In: ROSEMBERG, F. (Org.). Creche. São Paulo: Cortez: 1989.

ONGARI, B., MOLINA, P. A educadora de creche: construindo suas identidades. São Paulo: Cortez, 2003.

ONU. Assembleia Geral das Nações Unidas. Convenção das Nações Unidas sobre os Direitos da Criança. 1989. Disponível em <http:// www.onu-brasil.org.br/doc_crianca.php>. Acesso em 18/2/2009.

. Declaração Universal dos Direitos Humanos. 1948. Disponível em <http://www.onu-brasil.org.br/documentos_direitoshumanos.php>. Acesso em 19/3/2009.

Declaração Universal dos Direitos da Criança. 1959. Disponível em <http://www.dhnet.org.br/direitos/sip/onu/c_a/lex41. htm $>$. Acesso em 25/3/2009.

PENN, H. Primeira infância: a visão do Banco Mundial. Cadernos de Pesquisa (São Paulo), n.115, p.7-24, mar. 2002.

PEREIRA, E. W., TEIXEIRA, Z. A. A educação básica redimensionada. In: BRZEZINSKI, I. (Org.). LDB interpretada: diversos olhares se entrecruzam. São Paulo: Cortez, 1997.

PINTO, M. A infância como construção social. In: SARMENTO, M. J. As crianças: contextos e identidades. Braga: Centro de Estudos da Criança da Universidade do Minho, 1997. p.31-73.

, SARMENTO, M. J. (Org.). As crianças: contextos e identidades. Braga: Centro de Estudos da Criança da Universidade do Minho, 1997. 
POSTMAN, N. O desaparecimento da infância. Rio de Janeiro: Grafia, 1999.

PRIORI, M. D. História da criança no Brasil. 5.ed. São Paulo: Contexto, 1998.

QUINTANA, M. Poesias. Rio de Janeiro: Globo, 1962.

RECH, I. P. F. "Atividades" na educação infantil e posturas educativas. In: MARTINS FILHO, A. J. (Org.). Criança pede respeito: temas em educação infantil. Porto Alegre: Mediação, 2005.

ROCHA, E. A. C. A pesquisa em educação infantil no Brasil: trajetórias recente e perspectivas de consolidação de uma pedagogia. Campinas, 1998, 291 f. Tese (doutorado em Educação) - Faculdade de Educação, Universidade Estadual de Campinas.

ROSEMBERG, F. (Org.). Creche. São Paulo: Cortez, 1989.

. A criação de filhos pequenos: tendências e ambiguidades contemporâneas. In: RIBEIRO, I. (Org.). Famílias em processos contemporâneos: inovações culturais na sociedade brasileira. São Paulo: Loyola, 1995. (Seminários especiais).

Organizações multilaterais, Estado e políticas de educação infantil. Cadernos de Pesquisa (São Paulo), n.115, p.25-63, jan.-mar. 2002.

Panorama da educação infantil brasileira contemporânea. In: SIMPÓSIO DE EDUCAÇÃO INFANTIL: construindo o presente. Brasília, DF, 2002b. Anais.... Brasília: UNESCO, 2003. p.33-62. Disponível em <http://www.dominiopublico.gov.br/ download/texto/ue000311.pdf>. Acesso em 26/5/2009.

ROUSSEAU, J.-J. Emílio ou da educação. Trad. Sérgio Millet. São Paulo: Martins Fontes, 1995.

SÁ, C. P. de. A construção do objeto de pesquisa em representações sociais. Rio de Janeiro: EdUERJ, 1998.

SANTOS, B. de S. Pela mão de Alice: o social e o político na pós-modernidade. 4.ed. São Paulo: Cortez, 1997.

SARMENTO, M. J. A globalização e a infância: impactos na condição social e na escolaridade. In: GARCIA, R. L., LEITE FILHO, A. (Org.). Em defesa da educação infantil. Rio de Janeiro: DP\&A, 2001. 
SARMENTO, M. J. As crianças e a infância: definindo conceitos delimitando o campo. In: PINTO, M., SARMENTO, M. J. As crianças: contextos e identidades. Braga: Centro de Estudos da Criança da Universidade do Minho, 1997.

As culturas da infância nas encruzilhadas da segunda modernidade. In: CERISARA, A. B. (Org.). Crianças e miúdos: perspectiva sociopedagógicas da infância e educação. Lisboa: ASA, 2004.

Geração e alteridade: interrogação a partir da Sociologia da Infância. Educação E Sociedade (Campinas), v.26, n.91, p.361-78, mai.-ago. 2005. Disponível em <http://www.scielo.br/pdf/es/ v26n91/a03v2691.pdf>. Acesso em 14/5/2009.

. Visibilidade social e estudo da infância. In: , VASCONCELLOS, V. M. R. (Org.). Infância (in)visível. Araraquara: Junqueira \& Martin, 2007.

SAVIANI, D. Da nova LDB ao novo plano nacional de educação. 3.ed. rev. Campinas: Autores Associados, 2000. (Educação contemporânea).

SILVA, I. C. de A. L. e S. A construção da noção de cidadania infantil no Referencial Curricular Nacional para a Educação Infantil. Campinas, 2006, 221 f. Dissertação (mestrado em Educação) - Faculdade de Educação, Universidade Estadual de Campinas.

SIROTA, R. Emergência de uma Sociologia da Infância: evolução do objeto e do olhar. Cadernos de Pesquisa (São Paulo), n.112, p.7-31, mar. 2001.

SOARES, N. O Estatuto da Criança e do Adolescente e a função educacional da creche: projeto pedagógico do cuidar e educar, sem escolarizar. Franca, 2003, 154 f. Tese (doutorado em Serviço Social) - Faculdade de História, Direito e Serviço Social, Universidade Estadual Paulista "Júlio de Mesquita Filho".

SOARES, N. F. Direitos da criança: utopia ou realidade. In: PINTO, M., SARMENTO, M. J. As crianças: contextos e identidades. Braga: Centro de Estudos da Criança da Universidade do Minho. 1997.

Os direitos das crianças nas encruzilhadas da protecção e da participação. 2002. Disponível em <http://cedic.iec.uminho.pt/ 
Textos_de_Trabalho/textos/dircriencpropar.pdf $>$. Acesso em 4/1/2009.

SOARES, N. F., TOMÁS, C. A. Da emergência da participação à necessidade de consolidação da cidadania da infância... os intricados trilhos da acção da participação e do protagonismo social e político das crianças. In: SARMENTO, M. J., CERISARA, A. B. (Org.). Crianças e miúdos: perspectiva sociopedagógicas da infância e educação. Lisboa: ASA, 2004.

SOUZA, A. M. C. Educação infantil uma proposta de gestão municipal. Campinas: Papirus, 1996. (Magistério: formação e trabalho pedagógico).

SPINK, M. J. (Org.). O conhecimento no cotidiano: as representações sociais na perspectiva da Psicologia Social. São Paulo: Brasiliense, 1995.

TOMÁS, C. A. As crianças como prisioneiras de seu tempo-espaço: do reflexo da infância à reflexão sobre as crianças em contexto global. Currículo sem Fronteiras (Braga), v.6, n.1, p.41-55, jan.jun. 2006. Disponível em <http://www.curriculosemfronteiras. org/vol6iss1articles/tomas.pdf>. Acesso em 15/5/2009.

SOARES, N. O cosmopolitismo infantil: uma causa (sociológica) justa. 2004. Disponível em <http://www.aps.pt/cms/docs_ prv/docs/DPR460e8539509a8_1.pdf>. Acesso em 4/4/2009.

TRIVIÑOS, A. S. Introdução à pesquisa em ciências sociais: a pesquisa qualitativa em educação. São Paulo: Atlas, 1987.

UNESCO. Declaração Mundial sobre Educação para Todos: satisfação das necessidades básicas de aprendizagem. 1990. Disponível em <http://unesdoc.unesco.org/images/0008/000862/086291 por. pdf>. Acesso em 20/6/2009.

UNICEF. Declaração Universal dos Direitos da Criança. Disponível em <http://www.dhnet.org.br/direitos/sip/onu/c_a/lex41. htm>. Acesso em 4/6/2009.

Situação mundial da infância. Caderno Brasil UNICEF, Brasília, DF, jan. 2008. Disponível em <http://www.unicef.org/ brazil/pt/cadernobrasil2008.pdf>. Acesso em 12/3/2009. 
VYGOTSKY, L. S. A formação social da mente. 2.ed. Trad. José Cipolla Neto, Luis Silveira Menna Barreto e Solange Castro Afeche. São Paulo: Martins Fontes, 1988. (Psicologia e Pedagogia). 
SOBRE O LIVRO

Formato: $14 \times 21 \mathrm{~cm}$

Mancha: 23, $7 \times 42,10$ paicas

Tipologia: Horley Old Style 10,5/14

2010

EQUIPE DE REALIZAÇÃO

Coordenação Geral

Tulio Kawata 

